This document was prepared in conjunction with work accomplished under Contract No. DE-AC09-96SR18500 with the U. S. Department of Energy.

\title{
DISCLAIMER
}

This report was prepared as an account of work sponsored by an agency of the United States Government. Neither the United States Government nor any agency thereof, nor any of their employees, makes any warranty, express or implied, or assumes any legal liability or responsibility for the accuracy, completeness, or usefulness of any information, apparatus, product or process disclosed, or represents that its use would not infringe privately owned rights. Reference herein to any specific commercial product, process or service by trade name, trademark, manufacturer, or otherwise does not necessarily constitute or imply its endorsement, recommendation, or favoring by the United States Government or any agency thereof. The views and opinions of authors expressed herein do not necessarily state or reflect those of the United States Government or any agency thereof.

This report has been reproduced directly from the best available copy.

Available for sale to the public, in paper, from: U.S. Department of Commerce, National Technical Information Service, 5285 Port Royal Road, Springfield, VA 22161, phone: (800) 553-6847, fax: (703) 605-6900

email: orders@ntis.fedworld.gov

online ordering: http://www.ntis.gov/help/index.asp

Available electronically at http://www.osti.gov/bridge

Available for a processing fee to U.S. Department of Energy and its contractors, in paper, from: U.S. Department of Energy, Office of Scientific and Technical Information, P.O. Box 62, Oak Ridge, TN 37831-0062,

phone: (865)576-8401,

fax: (865)576-5728

email: $\underline{\text { reports@ adonis.osti.gov }}$ 


\section{Preliminary Results from Plutonium/Americium Solubility Studies Using Simulated Savannah River Site Waste Solutions}

Tracy S. Rudisill, David T. Hobbs, and Thomas B. Edwards

July 2004

Westinghouse Savannah River Company Aiken, SC 29808 
This page was intentionally left blank 


\section{Table of Contents}

\section{Section}

Summary

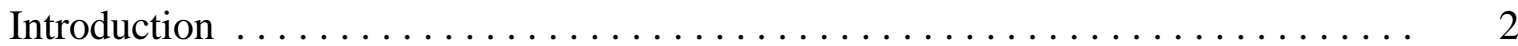

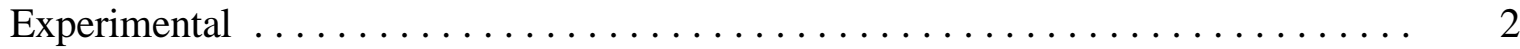

Constraints on Salt Concentrations $\ldots \ldots \ldots \ldots \ldots \ldots \ldots \ldots \ldots \ldots \ldots$

Statistical Design $\ldots \ldots \ldots \ldots \ldots \ldots \ldots \ldots \ldots \ldots \ldots \ldots \ldots \ldots$

Preparation of Salt Solutions $\ldots \ldots \ldots \ldots \ldots \ldots \ldots \ldots \ldots \ldots \ldots$

Sampling and Analysis of Salt Solutions $\ldots \ldots \ldots \ldots \ldots \ldots \ldots$

Results and Discussion $\ldots \ldots \ldots \ldots \ldots \ldots \ldots \ldots \ldots \ldots \ldots \ldots \ldots \ldots \ldots$

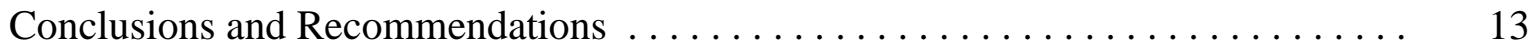

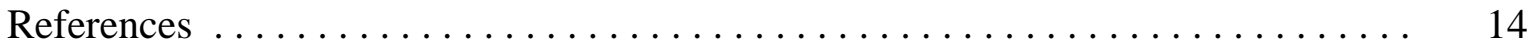




\section{List of Tables}

\section{Page}

Table $1 \quad$ Range of Salt Concentrations and Temperature in ........... 3 SRS Waste Tanks

Table 2 Design Points for Pu and Am Solubility Experiments ........ 5

Table 3 Starting Materials Used for Preparation of Salt Solutions . . . . . . . 6

Table $4 \quad$ Actual Concentration of Salt Solutions $\ldots \ldots \ldots \ldots \ldots \ldots \ldots$

Table $5 \quad$ Summary of First-Order Models Fit to the Solubility Data . . . . . . . . 9 From This Study

Table $6 \quad$ Summary of Modified Response Surface Models Fit to the . . . . . 11 Historical and Current Pu Solubility Data

Table $7 \quad$ Summary of "Optimal" Stepwise Regression Model Fit . . . . . . . 12 to the Historical and Current Pu Solubility Data

\section{List of Appendices}

Appendix A Tables and Exhibits Supporting the Development of the $\ldots \ldots \ldots 15$ Test Matrix

Appendix B Preparation of Salt Solutions $\ldots \ldots \ldots \ldots \ldots \ldots \ldots \ldots \ldots \ldots \ldots$

Appendix C Pu and Am Solubilities in Simulated Salt Solutions . . . . . . . . . 25

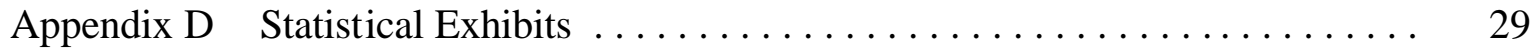




\title{
Preliminary Results from Plutonium/Americium Solubility Studies Using Simulated Savannah River Site Waste Solutions
}

\author{
Tracy S. Rudisill, David T. Hobbs, and Thomas B. Edwards \\ Westinghouse Savannah River Company \\ Aiken, SC 29808
}

\section{Summary}

To address the accelerated disposition of the supernate and salt portions of Savannah River Site (SRS) high level waste (HLW), solubility experiments were performed to develop a predictive capability for plutonium $(\mathrm{Pu})$ and americium $(\mathrm{Am})$ solubility. Preliminary results from the experiments indicate hydroxide $\left(\mathrm{OH}^{-}\right)$, carbonate $\left(\mathrm{CO}_{3}{ }^{2-}\right)$, nitrate $\left(\mathrm{NO}_{3}{ }^{-}\right)$and temperature are the predominant parameters affecting $\mathrm{Pu}$ and Am solubilities in alkaline salt solutions representative of those present in SRS waste tanks. This study used a statistically designed experimental matrix to evaluate the effects of six major anionic components $\left(\mathrm{OH}^{-}\right.$, aluminate $\left(\mathrm{Al}(\mathrm{OH})_{4}{ }^{-}\right)$, sulfate $\left(\mathrm{SO}_{4}{ }^{2-}\right), \mathrm{CO}_{3}{ }^{2-}, \mathrm{NO}_{3}{ }^{-}$, and nitrite $\left.\left(\mathrm{NO}_{2}{ }^{-}\right)\right)$and temperature $\left(25\right.$ and $\left.80{ }^{\circ} \mathrm{C}\right)$. This work extends previous data on $\mathrm{Pu}$ solubility to a wider range of solution compositions and is the first systematic evaluation of Am solubility in SRS waste solutions.

Analysis of the solubility data collected in nominal 1 month intervals over a 3-month period showed no time-dependence of the $\mathrm{Pu}$ and Am concentrations. However, the data scatter among the three data sets was sufficiently large to introduce considerable variance in model parameters. The data scatter likely indicates that not all solutions have obtained equilibrium after 3 months. We recommend that the testing continue to obtain an additional two sets of data as planned in the experimental design.

First-order models of the data indicate that the $\mathrm{Pu}$ solubility is a function of $\mathrm{OH}^{-}$and $\mathrm{CO}_{3}{ }^{2-}$ concentrations and that the Am solubility is a function of temperature and $\mathrm{OH}^{-}, \mathrm{CO}_{3}{ }^{2-}$, and $\mathrm{NO}_{3}{ }^{-}$ concentrations. These factors are statistically significant with at least $90 \%$ confidence. We also evaluated the Pu solubility data obtained in this study with previous data from the literature to develop a modified response surface model. All of the salt concentrations and temperature terms are statistically significant at the $90 \%$ confidence level. Upon completion of the solubility testing, we will incorporate the additional data into the response surface model and complete an evaluation of parameter sensitivity and validation of predictive performance. 


\section{Introduction}

The SRS is currently working to accelerate the disposition of the supernate and salt portions of the HLW contained in the SRS tank farm system. In particular, projects are underway to disposition salt waste according to its radionuclide content. For each disposition pathway, the $\mathrm{Pu}$ content of the waste is a dominating factor in determining the acceptance of the waste at the SRS Saltstone Facility. Since the specific activity of americium-241 (Am) is nominally a factor of 100 greater than $\mathrm{Pu}$, process conditions which increase its solubility in salt solutions are also a concern. The solubility of $\mathrm{Pu}$ and $\mathrm{Am}$ in acidic waste streams resulting from $\mathrm{Pu}$ purification activities is relatively well known. When waste solutions containing these elements are neutralized, coprecipitated with other metals, and discharged into the HLW system, the solubilities change with time and with conditions under which the waste is stored or evaporated.

The solubility of Pu in alkaline waste solutions representative of SRS HLW has only been measured for a narrow range of process conditions. Hobbs et al. [1] investigated the solubility of $\mathrm{Pu}$ and uranium in alkaline salt solutions comparable to the waste solutions to be processed by the In-Tank Precipitation Process. Plutonium solubility data from other studies have been evaluated and a predictive model developed as a function of the free hydroxide concentration; however, other constituents in the waste solution can change the Pu solubility by as much as three orders of magnitude for a given hydroxide concentration.[2] Americium solubility in SRS waste solutions has never been measured. Limited data are available for Hanford tank waste [3] and pure sodium hydroxide solutions.[4]

The objective of this work was to measure the solubility of Pu and Am in simulated SRS waste solutions. A statistically designed experiment was performed in which the composition and temperature of the waste solutions were varied over expected waste tank ranges. The statistically designed experiment also allowed modeling of the solubility data and development of a predictive capability given the composition and temperature of waste tank solutions.

Constituents of the simulated waste solutions included: $\mathrm{OH}^{-}, \mathrm{Al}(\mathrm{OH})_{4}{ }^{-}, \mathrm{SO}_{4}{ }^{2-}, \mathrm{CO}_{3}{ }^{2-}, \mathrm{NO}_{3}{ }^{-}$, and $\mathrm{NO}_{2}{ }^{-}$. Each anion was added to the waste solution in the sodium form. Solubility experiments were performed at 25 and $80^{\circ} \mathrm{C}$ to bound temperatures normally seen in SRS waste tanks. Once the simulated waste solutions were prepared, weapons grade $\mathrm{Pu}$ and $\mathrm{Am}$ were added as a nitrate solution. The $\mathrm{Pu}$ and Am solubility data presented in this report are limited to 3 data sets from the analysis of samples over a 3 month time period. The analysis of additional samples over a 2-3 month period is planned to ensure equilibrium concentrations were reached.

\section{Experimental}

\section{$\underline{\text { Constraints on Concentration }}$}

The range of salt concentrations and temperature expected in the SRS waste tanks are summarized in Table 1. Each anion was assumed to be in the sodium $\left(\mathrm{Na}^{+}\right)$form. 
Table 1 Range of Salt Concentrations and Temperature in SRS Waste Tanks

\begin{tabular}{ccc}
\hline \hline Parameter & $\begin{array}{c}\text { Low } \\
(\mathrm{M})\end{array}$ & $\begin{array}{c}\text { High } \\
(\mathrm{M})\end{array}$ \\
\hline $\mathrm{OH}^{-}$ & 0.0001 & 15 \\
$\mathrm{Al}(\mathrm{OH})_{4}^{-}$ & 0.001 & 1 \\
$\mathrm{SO}_{4}{ }^{--}$ & 0.001 & 0.5 \\
$\mathrm{CO}_{3}{ }^{2-}$ & 0.001 & 1 \\
$\mathrm{NO}_{3}^{-}$ & 0.1 & 6 \\
$\mathrm{NO}_{2}^{-}$ & 0.1 & 6 \\
& & \\
Temperature $\left({ }^{\circ} \mathrm{C}\right)$ & 25 & 80 \\
\hline
\end{tabular}

From the range of concentrations, one might expect that the preparation of solutions containing combinations of $\mathrm{OH}^{-}$and salt concentrations near the maximum levels are not possible due to the precipitation of one or more of the salts. To eliminate solution compositions that cannot be prepared, a series of constraints on the $\mathrm{OH}^{-}$and salt concentrations was utilized in the experimental design. The constraints are given by equations 1-3.

$$
\begin{gathered}
{\left[\mathrm{Al}(\mathrm{OH})_{4}^{-}\right] \leq \frac{1}{3}\left[\mathrm{NO}_{3}\right]} \\
{\left[\mathrm{OH}^{-}\right] \geq 0.4 \mathrm{M}+\left[\mathrm{Al}(\mathrm{OH})_{4}^{-}\right]} \\
{\left[\mathrm{Na}^{+}\right]_{\text {Total }} \leq 9 \mathrm{M}}
\end{gathered}
$$

The constraint on $\mathrm{Al}(\mathrm{OH})_{4}{ }^{-}$given by equation 1 is based on the stoichiometry of aluminum nitrate $\left(\mathrm{Al}\left(\mathrm{NO}_{3}\right)_{3}\right)$, the primary source of $\mathrm{Al}$ in the tank farm. The second constraint on $\mathrm{Al}(\mathrm{OH})_{4}{ }^{-}$ given by equation 2 was based on $\mathrm{Al}$ solubility studies in strongly alkaline solutions and ensures that $\mathrm{Al}(\mathrm{OH})_{4}{ }^{-}$remains soluble at the high end of its concentration range. The constraint on total $\mathrm{Na}^{+}$was empirically determined during this study when attempts to prepare solutions containing high salt concentrations failed even when the solution compositions were based on an experimental design utilizing constraints 1 and 2 . These results and information were important inputs to the experimental design process, which is discussed in the next section.

\section{$\underline{\text { Statistical Design }}$}

The goal of this study was to generate Pu and Am solubility data over the factor space defined by the seven factors (and their intervals of possible values) in Table 1. Historical data of interest to this study were available for Pu solubility but not for Am solubility. The data are provided in Table A.1 in Appendix A. The last column of this table provides an indicator for whether or not the historical data point satisfies constraints 1-3. Those data in Table A.1 that met the restrictions on the factor space imposed by constraints 1-3 (71 data points in all) served as the starting place for the development of the test matrix for this task. This was true even for data that extended slightly beyond the region defined by Table 1 (i.e. not all of the species were used 
to prepare the salt solutions). Thus, the test matrix designed for this study was selected to complement the previous Pu solubility efforts while providing a good initial basis for the study of the relationship between Am solubility and the factors of Table 1.

The Pu model of interest in this study is a response surface model in the 7 factors of Table 1 except for the quadratic temperature term, which is not of interest. Thus, the model of interest is made up of an intercept term, 7 main effect terms, 6 quadratic (or squared) terms, and 21 twoway interaction terms for a total of 35 terms. For the initial investigation of Am solubility, the model form of interest was a first-order model in the 7 factors.

Statistical routines are available to assist with experimental design problems. One such routine is the D-optimal routine available in JMP Version 3.2.6.[5] This routine selects a design of a specified size (i.e., number of design points) from a set of candidate points that optimizes the fitting of a specified model form. The optimization is relative to efficiency measures of the fitted model. (The optimal design criterion used by JMP Version 3.2.6 is D-optimality (i.e., to maximize the D-efficiency), where D-efficiency is a measure of design efficiency that is related to the determinant of the variance-covariance matrix of the design. [6])

To use this routine, there was a need to generate a set of candidate design points that were within the factor space of Table 1 and that satisfied constraints 1-3. This was accomplished by generating an initial, space-filling design using a modified, orthogonal Latin hypercube (OLH) approach. An OLH design is a space filling design that provides an opportunity for independently estimating main effects.[7] However, due to the restrictions imposed by constraints 1-3, the OLH was modified to satisfy these constraints. Temperature was excluded from this process, and each of the OLH points generated for the other factors was used to define candidate points, one at $25{ }^{\circ} \mathrm{C}$ and one at $80{ }^{\circ} \mathrm{C}$. Exhibit A.1 in Appendix A displays the correlations and corresponding scatterplot matrix of the candidate points generated using this approach. As seen in this exhibit, the restrictions imposed by constraints 1-3 lead to correlations in the candidate design points among the factors.

A set of special candidate design points was added to these OLH points. These points were added (at temperatures of 25 and $80{ }^{\circ} \mathrm{C}$ ) to represent possible solution concentrations that may result from evaporator operations. These selective design points are provided in Table A.2 of Appendix A and together with the OLH points, they provided the set of candidate design points that was submitted to the D-Optimal routines from which 8 optimal points were selected to support the fitting of a first-order model relating Am solubility to the 7 factors of this study. Exhibit A.2 provides the information generated by the routine, which was conducted for 1000 iterations as indicated in the exhibit. Some correlations among these design points at or near $50 \%$ are observed in this exhibit; this is an artifact of the restrictions imposed by constraints 1-3. Table A.3 in Appendix A provides a listing of these 8 design points.

Next, the D-Optimal routine of JMP Versions 3.2.6 was used a second time. In this run of the routine, the set of candidate design points was formed by adding the 71 acceptable data points from Table A.1, the OLH points, and the special data points of Table A.2. The model of interest for this run was the modified response surface model of interest in this study of Pu solubilities. For this use of D-Optimal, which was run for 1000 iterations, the 71 points from Table A.1 and 
the 8 points from Table A.3 were forced into the test matrix and the routine was asked to complement these 79 points with 12 additional, "optimal" points for a total of 91 design points. The results from this run of D-Optimality are provided in Exhibit A.3 of Appendix A, and the final test matrix is given in Table 2. The low value for the G-efficiency of this design and the high correlations among the model terms as provided in the exhibit suggest that it is an ambitious undertaking to push the currently available set of 71 data points to a set of 91 for the fitting of the model of interest.

Table 2 Design Points for Pu and Am Solubility Experiments

\begin{tabular}{cccccccc}
\hline \hline Solution & $\begin{array}{c}\mathrm{OH}^{-} \\
(\mathrm{M})\end{array}$ & $\begin{array}{c}\mathrm{Al}(\mathrm{OH})_{4}{ }^{-} \\
(\mathrm{M})\end{array}$ & $\begin{array}{c}\mathrm{SO}_{4}{ }^{2-} \\
(\mathrm{M})\end{array}$ & $\begin{array}{c}\mathrm{CO}_{3}{ }^{2-} \\
(\mathrm{M})\end{array}$ & $\begin{array}{c}\mathrm{NO}_{3}{ }^{-} \\
(\mathrm{M})\end{array}$ & $\begin{array}{c}\mathrm{NO}_{2}{ }^{-} \\
(\mathrm{M})\end{array}$ & $\begin{array}{c}\text { Temp } \\
\left({ }^{\circ} \mathrm{C}\right)\end{array}$ \\
\hline 1 & 15.00 & 0.0010 & 0.0010 & 0.0010 & 0.1000 & 0.1000 & 25 \\
2 & 15.00 & 0.0010 & 0.0010 & 0.0010 & 0.1000 & 0.1000 & 85 \\
3 & 5.512 & 0.0167 & 0.0158 & 0.9109 & 0.7523 & 0.8151 & 85 \\
4 & 0.8722 & 0.1323 & 0.0104 & 0.8877 & 4.8795 & 1.2663 & 25 \\
5 & 0.8722 & 0.1323 & 0.0104 & 0.8877 & 4.8795 & 1.2663 & 85 \\
6 & 2.268 & 0.6631 & 0.2065 & 0.0591 & 2.4717 & 2.9888 & 85 \\
7 & 1.779 & 0.1133 & 0.1209 & 0.3627 & 0.6260 & 5.4283 & 85 \\
8 & 1.640 & 0.4130 & 0.3459 & 0.2389 & 1.5864 & 4.1019 & 25 \\
9 & 3.384 & 0.6089 & 0.2157 & 0.4540 & 2.5616 & 0.8756 & 25 \\
10 & 2.895 & 0.7561 & 0.4826 & 0.2217 & 2.9888 & 0.6283 & 85 \\
11 & 5.837 & 0.1128 & 0.4091 & 0.2914 & 0.3547 & 0.9686 & 85 \\
12 & 2.756 & 0.0482 & 0.0880 & 0.9342 & 0.1686 & 3.5988 & 25 \\
13 & 1.221 & 0.6012 & 0.1112 & 0.0358 & 4.1477 & 1.8151 & 25 \\
14 & 0.4536 & 0.0313 & 0.1074 & 0.0726 & 3.6446 & 3.4159 & 25 \\
15 & 1.291 & 0.7406 & 0.1809 & 0.9497 & 2.5012 & 0.1686 & 25 \\
16 & 1.291 & 0.7406 & 0.1809 & 0.9497 & 2.5012 & 0.1686 & 85 \\
17 & 2.070 & 0.0500 & 0.4671 & 0.8258 & 0.2500 & 0.7942 & 25 \\
18 & 0.8606 & 0.0672 & 0.1809 & 0.9497 & 0.4663 & 0.1105 & 85 \\
19 & 0.6280 & 0.0067 & 0.4362 & 0.4463 & 0.5151 & 0.4174 & 85 \\
20 & 2.628 & 0.0246 & 0.0842 & 0.0126 & 0.1593 & 0.1453 & 85 \\
\hline
\end{tabular}

Preparation of Salt Solutions

The 20 salt solutions specified as design points for the $\mathrm{Pu}$ and Am solubility experiments were based on the target concentrations given in Table 2. The solutions were prepared using ACS certified reagents. The starting materials are shown in Table 3. The amount of each starting material was based on the preparation of $100 \mathrm{~mL}$ of salt solution. 
WSRC-TR-2004-00349

Revision 0

Table 3 Starting Materials Used for Preparation of Salt Solutions

\begin{tabular}{|c|c|c|}
\hline Chemical & $\begin{array}{c}\text { Concentration } \\
(\mathrm{wt} \%)\end{array}$ & Formula \\
\hline Sodium Hydroxide & 50 & $\mathrm{NaOH}$ \\
\hline Aluminum Nitrate Nonahydrate & & $\mathrm{Al}\left(\mathrm{NO}_{3}\right)_{3} \cdot 9 \mathrm{H}_{2} \mathrm{O}$ \\
\hline Sodium Sulfate Decahydrate & & $\mathrm{Na}_{2} \mathrm{SO}_{4} \cdot 10 \mathrm{H}_{2} \mathrm{O}$ \\
\hline Sodium Carbonate Monohydrate & & $\mathrm{Na}_{2} \mathrm{CO}_{3} \cdot \mathrm{H}_{2} \mathrm{O}$ \\
\hline Sodium Nitrate & & $\mathrm{NaNO}_{3}$ \\
\hline Sodium Nitrite & & $\mathrm{NaNO}_{2}$ \\
\hline
\end{tabular}

The solutions were prepared by initially transferring the desired amount of $50 \mathrm{wt} \% \mathrm{NaOH}$ to a $250 \mathrm{~mL}$ beaker. The target amount of $\mathrm{Al}\left(\mathrm{NO}_{3}\right)_{3} \bullet 9 \mathrm{H}_{2} \mathrm{O}$ was then dissolved in $4-5 \mathrm{~mL}$ of deionized water in a separate beaker and mixed with the $\mathrm{NaOH}$ until all solids dissolved. The beaker was rinsed with 2,1-2 mL aliquots of deionized water. The $250 \mathrm{~mL}$ beaker was stirred using a magnetic stirring bar. The target masses of $\mathrm{Na}_{2} \mathrm{SO}_{4} \bullet 10 \mathrm{H}_{2} \mathrm{O}, \mathrm{Na}_{2} \mathrm{CO}_{3} \cdot \mathrm{H}_{2} \mathrm{O}, \mathrm{NaNO}_{3}$, and $\mathrm{NaNO}_{2}$ were then added to the caustic solution in the order indicated. Each salt was dissolved before the next was added to the solution. The contents of the beaker were stirred and heated (at $<80^{\circ} \mathrm{C}$ ) when necessary to dissolve the salts. A watch glass containing water was placed on top of the beaker to reduce evaporation losses; however, periodically it was necessary to add deionized water to the beaker to replace evaporated water or promote the dissolution of one of the salts. After dissolving the salts, the solutions were transferred to a graduated cylinder. The beaker was rinsed with $3,1-2 \mathrm{~mL}$ aliquots of deionized water. The contents of the graduated cylinder were then diluted to $100 \mathrm{~mL}$. The salt solutions were transferred to plastic bottles and then back into the graduated cylinder to mix the solution and ensure the residual volume remaining in the cylinder was the same composition as the solution transferred to the bottle. This procedure was repeated 3 times. A summary of the target and actual masses of each starting material used to prepare the salt solutions is provided in Appendix B.

During the preparation of the salt solutions, it was necessary to reduce the $\mathrm{SO}_{4}{ }^{2-}$ or $\mathrm{CO}_{3}{ }^{2-}$ concentrations of several solutions to completely dissolve the $\mathrm{Na}_{2} \mathrm{SO}_{4} \cdot 10 \mathrm{H}_{2} \mathrm{O}$ and $\mathrm{Na}_{2} \mathrm{CO}_{3} \cdot \mathrm{H}_{2} \mathrm{O}$. The reduction in the target mass of the starting material is noted in Appendix B (see Table B.1) for these solutions. In addition, the final volume of several solutions was slightly greater than $100 \mathrm{~mL}$. During solution preparation, deionized water was added to aid in the dissolution of the salts. After the dissolution of the starting materials, the final volume of the solutions could not be evaporated below $100 \mathrm{~mL}$ without the precipitation of solids. The required adjustments in volume are noted in Appendix B, Table B.2. The actual concentrations of the salt solutions and equilibration temperature are given in Table 4. 
Table 4 Actual Concentration of Salt Solutions

\begin{tabular}{cccccccc}
\hline \hline Solution & $\begin{array}{c}\mathrm{OH}^{-} \\
(\mathrm{M})\end{array}$ & $\begin{array}{c}\mathrm{Al}(\mathrm{OH})_{4}{ }^{-} \\
(\mathrm{M})\end{array}$ & $\begin{array}{c}\mathrm{SO}_{4}{ }^{2-} \\
(\mathrm{M})\end{array}$ & $\begin{array}{c}\mathrm{CO}_{3}{ }^{2-} \\
(\mathrm{M})\end{array}$ & $\begin{array}{c}\mathrm{NO}_{3}{ }^{-} \\
(\mathrm{M})\end{array}$ & $\begin{array}{c}\mathrm{NO}_{2}{ }^{-} \\
(\mathrm{M})\end{array}$ & $\begin{array}{c}\mathrm{Temp} \\
\left({ }^{\circ} \mathrm{C}\right)\end{array}$ \\
\hline $1 \mathrm{~A}$ & 15.00 & 0.0010 & 0 & 0.0010 & 0.1001 & 0.1000 & 25 \\
$2 \mathrm{~A}$ & 15.00 & 0.0010 & 0 & 0.0010 & 0.1001 & 0.1000 & 80 \\
$3 \mathrm{~A}$ & 5.512 & 0.0167 & 0.0159 & 0.6001 & 0.7523 & 0.8154 & 80 \\
4 & 0.8730 & 0.1323 & 0.0105 & 0.8878 & 4.880 & 1.266 & 25 \\
5 & 0.8723 & 0.1323 & 0.0104 & 0.8877 & 4.880 & 1.266 & 80 \\
6 & 2.268 & 0.6631 & 0.2066 & 0.0591 & 2.472 & 2.989 & 80 \\
7 & 1.780 & 0.1133 & 0.1209 & 0.3630 & 0.6262 & 5.428 & 80 \\
8 & 1.478 & 0.3721 & 0.3117 & 0.2152 & 1.429 & 3.695 & 25 \\
$9 \mathrm{~A}$ & 3.350 & 0.6029 & 0.2136 & 0.2476 & 2.536 & 0.8670 & 25 \\
$10 \mathrm{~A}$ & 2.895 & 0.7561 & 0.2500 & 0.2217 & 2.989 & 0.6284 & 80 \\
$11 \mathrm{~A}$ & 5.639 & 0.1090 & 0.2416 & 0.2816 & 0.3429 & 0.9360 & 80 \\
12 & 2.610 & 0.0457 & 0.0833 & 0.8847 & 0.1597 & 3.408 & 25 \\
13 & 1.221 & 0.6012 & 0.1113 & 0.0358 & 4.148 & 1.815 & 25 \\
14 & 0.4537 & 0.0313 & 0.1075 & 0.0726 & 3.645 & 3.416 & 25 \\
15 & 1.291 & 0.7406 & 0.1809 & 0.9498 & 2.501 & 0.1687 & 25 \\
16 & 1.291 & 0.7406 & 0.1809 & 0.9498 & 2.501 & 0.1687 & 80 \\
17 & 2.070 & 0.0501 & 0.4671 & 0.8259 & 0.2503 & 0.7944 & 25 \\
18 & 0.8611 & 0.0672 & 0.1810 & 0.9498 & 0.4665 & 0.1106 & 80 \\
19 & 0.6281 & 0.0067 & 0.4362 & 0.4463 & 0.5151 & 0.4176 & 80 \\
20 & 2.628 & 0.0246 & 0.0843 & 0.0126 & 0.1596 & 0.1455 & 80 \\
\hline
\end{tabular}

Once the salt solutions were prepared, nominally $10 \mathrm{~mL}$ of each solution were transferred to 5 , $15 \mathrm{~mL}$ plastic bottles. The intent of preparing 5 sample bottles for each solution was to allow the removal of a separate bottle each time the solutions were sampled. This procedure eliminated the need to remove the entire solution from a temperature-controlled environment during sampling and allowed the solutions to be maintained at the desired temperature using equipment which was not radioactively contaminated.

The weapons grade Pu added to the salt solutions was initially purified and concentrated by anion exchange. Likewise, Am recovered from the raffinate of a Pu anion exchange column run was purified and concentrated using a chelating resin. The $\mathrm{Pu}^{4+}$ and $\mathrm{Am}^{3+}$ nitrate solutions were used to prepare a stock solution containing $1000 \mu \mathrm{g} / \mathrm{mL}$ each of Pu and Am in nominally $1 \mathrm{M}$ nitric acid $\left(\mathrm{HNO}_{3}\right)$. Each of the salt solution sample bottles was spiked with $50 \mu \mathrm{L}$ of the $\mathrm{Pu} / \mathrm{Am}$ stock solution. During the Pu/Am additions, the sample bottles were handled in a way to prevent the outside from becoming contaminated. The bottles were surveyed for contamination and placed in $250 \mathrm{~mL}$ plastic bottles which provided secondary containment for the solutions. One to 3 sample bottles were placed in each of the bottles. The $250 \mathrm{~mL}$ bottles were secured in New Brunswick Scientific Innova 4080 Incubator Shakers to maintain the solutions at the desired temperature. The temperature of the incubator shakers were continuously monitored using calibrated thermistors. Variations in temperature were held to less than $\pm 1^{\circ} \mathrm{C}$. 
Three sets of the salt solution samples were analyzed at nominally 1 month intervals. To prepare the samples for analysis, $5-8 \mathrm{~mL}$ of solution were removed from a sample bottle using a $10 \mathrm{~mL}$ disposable syringe with a piece of plastic tubing attached to facilitate reaching into the sample bottle. The solution was expelled through an Acrodisc ${ }^{\circledR} 0.45 \mu \mathrm{m}$ Versapor ${ }^{\circledR}$ membrane disk filter into a clean glass vial. A $1 \mathrm{~mL}$ aliquot of the filtered solution was slowly transferred (to reduce the rate of gas evolution) by pipette into a glass sample vial containing 2 or $4 \mathrm{~mL}$ of $5 \mathrm{M}$ $\mathrm{HNO}_{3}$. The $4 \mathrm{~mL}$ aliquot of acid was used to neutralize salt solution samples containing $15 \mathrm{M}$ $\mathrm{NaOH}$; a $2 \mathrm{ml}$ aliquot of acid was used to neutralize the remainder of the samples. The resulting acid concentrations in the samples were 1-3M. The acidified samples were analyzed for $\mathrm{Pu}$

$\left({ }^{238} \mathrm{Pu},{ }^{239} \mathrm{Pu}\right.$, and ${ }^{240} \mathrm{Pu}$ ) by thenolytrifluoroacetone (TTA) extraction and alpha pulse height analysis (APHA). The Am concentration was measured by gamma pulse height analysis (GPHA).

Since 11 of the salt solutions were equilibrated at $80^{\circ} \mathrm{C}$, care was taken during the sampling procedure to ensure that the solutions stayed at or near temperature to prevent the precipitation of $\mathrm{Pu}$ and $\mathrm{Am}$ as the solutions cooled. To maintain the salt solutions at this temperature, a drying oven was used to preheat to $80^{\circ} \mathrm{C}$ the syringes, tubing, filter disks, glass vials, and pipette tips used in the sampling procedure. When the sample bottles were removed from the incubator shaker, the bottle(s) not being sampled were placed in the drying oven to maintain the solution(s) at $80^{\circ} \mathrm{C}$.

To check the consistency of the Pu and Am analyses, blank and standard Pu/Am solutions were analyzed with each set of salt solutions. The blank solutions were randomly selected samples of the 20 salt solutions which did not contain Pu and Am. A standard solution containing $0.5 \mu \mathrm{g} / \mathrm{mL}$ of $\mathrm{Pu}$ and $\mathrm{Am}$ was prepared by diluting a $50 \mu \mathrm{L}$ aliquot of the Pu/Am stock solution with $10 \mathrm{~mL}$ of $2 \mathrm{M} \mathrm{HNO}_{3}$ followed by the dilution of a $1 \mathrm{~mL}$ aliquot of the resulting solution with $9 \mathrm{~mL}$ of $2 \mathrm{M} \mathrm{HNO}_{3}$.

\section{Results and Discussion}

The Pu and Am solubilities measured in each of the salt solutions as a function of the equilibration time are presented in Appendix C. The Pu and Am analyses for the blank and standard solutions are also included for each data set. In this section these solubility data are reviewed and their relationship to the 7 factors of this study are explored and modeled. The statistical analyses supporting this review were conducted using JMP Version 5 from SAS Institute, Inc.[8]

Exhibit D.1 in Appendix D provides plots of the Pu and Am data by sample number. As seen in these plots, the behavior of these solubility data over time is somewhat erratic, which brings into question the equilibrium of the $\mathrm{Pu}$ and $\mathrm{Am}$ in the solution and raises the question of how to best represent the solubilities for each of these experimental trials. The first question is being addressed by additional samples being taken at two times in the future to provide more data to assess the stability of these solutions. The second question is addressed in the preliminary 
analysis by using each of the individual 3 samples and their average to represent the solubility data for each of the 20 trials during the statistical modeling process.

Exhibit D.2 in Appendix D provides plots of the Pu and Am data by each factor for each of the 3 samples and their average. As discussed above, a first-order model in the 7 factors was of interest for exploring the relationship between the factors and Am solubility. For completeness, the Pu solubility data was modeled in the same manner. Exhibit D.3 in Appendix D provides the (summary) results generated by the JMP software used to conduct these fits. As seen in Exhibit D.3, the $\mathrm{R}^{2}$ values for these fits ran from a low of $60 \%$ to a high of $84 \%$. Table 5 was prepared to allow for easy comparisons across these results. The estimated effect of each of the factors for each of the first-order models of Exhibit D.3 is provided in this table, where shaded entries are statistically significant with at least $90 \%$ confidence.

Table 5 Summary of First-Order Models Fit to the Solubility Data from This Study

\begin{tabular}{ccccccccc}
\hline \hline $\begin{array}{c}\text { First-Order } \\
\text { Model }\end{array}$ & Intercept & $\begin{array}{c}\text { Temp } \\
\left({ }^{\circ} \mathrm{C}\right)\end{array}$ & $\begin{array}{c}\mathrm{OH}^{-} \\
(\mathrm{M})\end{array}$ & $\begin{array}{c}\mathrm{Al}(\mathrm{OH})_{4}{ }^{-} \\
(\mathrm{M})\end{array}$ & $\begin{array}{c}\mathrm{SO}_{4}{ }^{2-} \\
(\mathrm{M})\end{array}$ & $\begin{array}{c}\mathrm{CO}_{3}{ }^{2-} \\
(\mathrm{M})\end{array}$ & $\begin{array}{c}\mathrm{NO}_{3}{ }^{-} \\
(\mathrm{M})\end{array}$ & $\begin{array}{c}\mathrm{NO}_{2}{ }^{-} \\
(\mathrm{M})\end{array}$ \\
\hline Sample 1 Pu & $-3.79 \mathrm{E}-7$ & $-1.68 \mathrm{E}-8$ & $1.30 \mathrm{E}-6$ & $-1.74 \mathrm{E}-7$ & $1.21 \mathrm{E}-7$ & $5.20 \mathrm{E}-6$ & $4.25 \mathrm{E}-8$ & $4.08 \mathrm{E}-7$ \\
Sample 2 Pu & $1.40 \mathrm{E}-6$ & $-3.59 \mathrm{E}-8$ & $1.20 \mathrm{E}-6$ & $1.20 \mathrm{E}-6$ & $-7.23 \mathrm{E}-7$ & $5.00 \mathrm{E}-6$ & $-1.78 \mathrm{E}-7$ & $3.38 \mathrm{E}-7$ \\
Sample 3 Pu & $-2.00 \mathrm{E}-6$ & $-1.23 \mathrm{E}-8$ & $1.20 \mathrm{E}-6$ & $3.00 \mathrm{E}-6$ & $3.50 \mathrm{E}-6$ & $5.90 \mathrm{E}-6$ & $7.69 \mathrm{E}-7$ & $1.48 \mathrm{E}-7$ \\
Average $\mathrm{Pu}$ & $-2.05 \mathrm{E}-7$ & $-2.16 \mathrm{E}-8$ & $1.30 \mathrm{E}-6$ & $-5.06 \mathrm{E}-7$ & $9.64 \mathrm{E}-7$ & $5.40 \mathrm{E}-6$ & $2.11 \mathrm{E}-7$ & $2.98 \mathrm{E}-7$ \\
Sample 1 Am & $3.65 \mathrm{E}-7$ & $-1.76 \mathrm{E}-8$ & $4.56 \mathrm{E}-7$ & $2.03 \mathrm{E}-7$ & $9.57 \mathrm{E}-7$ & $1.00 \mathrm{E}-6$ & $3.57 \mathrm{E}-9$ & $1.55 \mathrm{E}-7$ \\
Sample 2 Am & $1.80 \mathrm{E}-6$ & $-2.87 \mathrm{E}-8$ & $2.58 \mathrm{E}-7$ & $2.00 \mathrm{E}-6$ & $-3.19 \mathrm{E}-7$ & $1.70 \mathrm{E}-6$ & $-1.46 \mathrm{E}-7$ & $1.68 \mathrm{E}-7$ \\
Sample 3 Am & $-1.00 \mathrm{E}-6$ & $-6.40 \mathrm{E}-9$ & $4.82 \mathrm{E}-7$ & $-2.00 \mathrm{E}-6$ & $2.20 \mathrm{E}-6$ & $2.60 \mathrm{E}-6$ & $9.52 \mathrm{E}-7$ & $-1.21 \mathrm{E}-8$ \\
Average Am & $3.09 \mathrm{E}-7$ & $-1.76 \mathrm{E}-8$ & $3.98 \mathrm{E}-7$ & $1.70 \mathrm{E}-7$ & $9.41 \mathrm{E}-7$ & $1.80 \mathrm{E}-6$ & $2.70 \mathrm{E}-7$ & $1.03 \mathrm{E}-7$ \\
\hline Note: Shaded entries are statistically significant with at least 90\% confidence.
\end{tabular}

Since a first-order model was of primary interest for the Am solubility data, one additional fit was conducted for the Am data using JMP. In this fit, the average Am solubility data were used to represent the response, and this response was modeled using Temperature, $\mathrm{OH}^{-}, \mathrm{CO}_{3}{ }^{2-}$, and $\mathrm{NO}_{3}{ }^{-}$, all of the terms that showed as significant for a least one of the models in Exhibit D.3. The results from this fit are provided in Exhibit D.4 of Appendix D. The $\mathrm{R}^{2}$ value of this fit is $\sim 82 \%$, all of the terms of the model are statistically significant with at least $90 \%$ confidence, and the fitted model for Am solubility is given by equation 4.

$$
\operatorname{Am}(\mathrm{M})=1.10 \mathrm{E}-6-1.91 \mathrm{E}-8 \mathrm{Temp}+3.54 \mathrm{E}-7\left[\mathrm{OH}^{-}\right]+1.60 \mathrm{E}-6\left[\mathrm{CO}_{3}^{2-}\right]+2.26 \mathrm{E}-7\left[\mathrm{NO}_{3}^{-}\right]
$$

Thus, the model given by equation 4 provides the starting place for understanding, through this data-driven approach, the relationship of Am solubility to the factors of Table 1. After the remaining two samples are taken from the 20 experimental trials for this study, the data from those samples will be combined with the sample data presented in this report and the models fitting process will be repeated.

Once again for completeness, a similar first-order fit was conducted for the Pu data using JMP. In this fit, the average $\mathrm{Pu}$ solubility data were used to represent the response, and this response was modeled using only $\mathrm{OH}^{-}$and $\mathrm{CO}_{3}{ }^{2-}$, the only terms that showed as significant for a least one of the models in Exhibit D.3. The results from this fit are provided in Exhibit D.5 of 
Appendix D. The $\mathrm{R}^{2}$ value of this fit is $\sim 75 \%$, both factors are statistically significant with at least $90 \%$ confidence, and the fitted model for Pu solubility is given by equation 5 .

$$
\mathrm{Pu}(\mathrm{M})=-7.48 \mathrm{E}-8+1.20 \mathrm{E}-6\left[\mathrm{OH}^{-}\right]+4.90 \mathrm{E}-6\left[\mathrm{CO}_{3}^{2-}\right]
$$

Although equation 5 provides what is felt to be the best first-order model for the Pu solubility data from this study, the primary goal for the modeling of Pu solubility was to combine available historical data with the current results to allow for the study of a more complex model form (i.e., a modified response surface model, as described above). The plots of Exhibit D.6 in Appendix $\mathrm{D}$ are presented as a prelude to this modeling effort. These plots show the Pu results from this study (all 3 samples and the sample average) versus the 7 factors of interest. Superimposed on these plots are the historical Pu solubility data. Different colors and symbols are used to represent the historical data sets as well as the current results. A dramatic feature of these plots is seen in the behavior of one of the previous data sets relative to the other plotted points. Points from this data set are represented by orange triangles in these plots, and the structure of the relationship between $\mathrm{Pu}$ solubility and the factors under study as revealed in these plots is often very different from that of the other data. These data were from a study by Delegard [3] and it is believed that the apparent differences in these data relative to the other data are due to other complexants being involved in Delegard's study. As a consequence, these data were excluded from the modeling efforts of this study.

Exhibit D.7 in Appendix D provides the results from the fit of a modified response surface model in the 7 factors (with the quadratic temperature term removed) to historical data complemented in turn by the Pu solubility data for each of the 3 samples and by the averages for the 20 trials. The $\mathrm{R}^{2}$ values for these fitted models are all over $99.5 \%$. Such high $\mathrm{R}^{2}$ values may be due in part to the large number of candidate terms available to account for the variation in the solubility data. Table 6 was prepared to facilitate a closer look at the results for each of the fitted models. It provides a listing of the candidate terms and their estimated coefficients for each of the fits. A shaded entry indicates a term in a model that is statistically significant with at least $90 \%$ confidence. Even with the sample-to-sample variation in the Pu solubility measurements, there is some consistency in the terms that show up as statistically significant across these models. 
Table 6 Summary of Modified Response Surface Models Fit to the Historical and Current Pu Solubility Data

\begin{tabular}{|c|c|c|c|c|}
\hline $\begin{array}{l}\text { Estimated } \\
\text { Coefficient }\end{array}$ & $\begin{array}{c}\text { Sample } \\
1\end{array}$ & $\begin{array}{c}\text { Sample } \\
2\end{array}$ & $\begin{array}{c}\text { Sample } \\
3\end{array}$ & Average \\
\hline Intercept & $1.00 \mathrm{E}-06$ & $6.07 \mathrm{E}-07$ & $4.00 \mathrm{E}-07$ & $7.15 \mathrm{E}-07$ \\
\hline $\mathrm{Al}(\mathrm{OH})_{4}^{-}$ & $8.00 \mathrm{E}-06$ & $1.90 \mathrm{E}-05$ & $2.00 \mathrm{E}-06$ & $9.00 \mathrm{E}-06$ \\
\hline $\mathrm{CO}_{3}^{2-}$ & $-1.00 \mathrm{E}-05$ & $-8.96 \mathrm{E}-06$ & $-2.00 \mathrm{E}-05$ & $-1.00 \mathrm{E}-05$ \\
\hline $\mathrm{NO}_{2}^{-}$ & $-8.82 \mathrm{E}-07$ & $-7.48 \mathrm{E}-07$ & $-2.08 \mathrm{E}-07$ & $-6.13 \mathrm{E}-07$ \\
\hline $\mathrm{NO}_{3}^{-}$ & $-6.88 E-07$ & $-7.34 \mathrm{E}-07$ & $-2.97 \mathrm{E}-07$ & $-5.73 \mathrm{E}-07$ \\
\hline $\mathrm{OH}^{-}$ & $2.94 \mathrm{E}-07$ & $-6.57 \mathrm{E}-07$ & $-2.39 \mathrm{E}-09$ & $-1.22 \mathrm{E}-07$ \\
\hline $\mathrm{SO}_{4}^{2-}$ & $1.00 \mathrm{E}-06$ & $-2.00 \mathrm{E}-05$ & $5.00 \mathrm{E}-06$ & $-3.37 \mathrm{E}-06$ \\
\hline Temperature & $-3.43 E-08$ & $8.46 \mathrm{E}-09$ & $-1.48 \mathrm{E}-08$ & $-1.35 \mathrm{E}-08$ \\
\hline $\mathrm{CO}_{3}{ }^{2-*} * \mathrm{Al}(\mathrm{OH})_{4}{ }^{-}$ & $-3.19 E-06$ & $-9.89 \mathrm{E}-06$ & $-5.29 \mathrm{E}-06$ & $-6.12 \mathrm{E}-06$ \\
\hline $\mathrm{NO}_{2}{ }^{-} * \mathrm{Al}(\mathrm{OH})_{4}^{-}$ & $3.72 \mathrm{E}-07$ & $-1.92 \mathrm{E}-06$ & $5.84 \mathrm{E}-07$ & $-3.21 \mathrm{E}-07$ \\
\hline $\mathrm{NO}_{3}^{-*} \mathrm{Al}(\mathrm{OH})_{4}^{-}$ & $-3.98 \mathrm{E}-06$ & $-7.31 \mathrm{E}-06$ & $-2.07 \mathrm{E}-06$ & $-4.45 \mathrm{E}-06$ \\
\hline $\mathrm{OH}^{-*} \mathrm{Al}(\mathrm{OH})_{4}^{-}$ & $-1.77 \mathrm{E}-06$ & $-3.75 E-06$ & $1.00 \mathrm{E}-06$ & $-1.36 \mathrm{E}-06$ \\
\hline $\mathrm{SO}_{4}^{2-*} \mathrm{Al}(\mathrm{OH})_{4}^{-}$ & $6.00 \mathrm{E}-06$ & $4.20 \mathrm{E}-05$ & $6.00 \mathrm{E}-06$ & $1.80 \mathrm{E}-05$ \\
\hline Temperature* $\mathrm{Al}(\mathrm{OH})_{4}{ }^{-}$ & $-1.04 \mathrm{E}-07$ & $-1.14 \mathrm{E}-07$ & $-1.52 \mathrm{E}-07$ & $-1.23 \mathrm{E}-07$ \\
\hline $\mathrm{NO}_{2}{ }^{-} * \mathrm{CO}_{3}{ }^{2-}$ & $2.00 \mathrm{E}-06$ & $1.00 \mathrm{E}-06$ & $5.13 \mathrm{E}-07$ & $1.00 \mathrm{E}-06$ \\
\hline $\mathrm{NO}_{3}{ }^{-*} \mathrm{CO}_{3}{ }^{2-}$ & $5.84 \mathrm{E}-07$ & 3.19E-07 & $3.00 \mathrm{E}-06$ & $1.00 \mathrm{E}-06$ \\
\hline $\mathrm{OH}^{-} * \mathrm{CO}_{3}{ }^{2-}$ & $4.00 \mathrm{E}-06$ & $4.00 \mathrm{E}-06$ & $5.00 \mathrm{E}-06$ & $4.00 \mathrm{E}-06$ \\
\hline $\mathrm{SO}_{4}{ }^{2-} * \mathrm{CO}_{3}{ }^{2-}$ & $1.20 \mathrm{E}-05$ & $1.90 \mathrm{E}-05$ & $1.80 \mathrm{E}-05$ & $1.60 \mathrm{E}-05$ \\
\hline Temperature ${ }^{*} \mathrm{CO}_{3}{ }^{2-}$ & 2.82E-08 & 7.32E-09 & $3.22 \mathrm{E}-08$ & $2.26 \mathrm{E}-08$ \\
\hline $\mathrm{NO}_{3}^{-} * \mathrm{NO}_{2}^{-}$ & $1.62 \mathrm{E}-07$ & $-1.41 \mathrm{E}-07$ & $1.08 \mathrm{E}-07$ & 4.30E-08 \\
\hline $\mathrm{OH}^{-} * \mathrm{NO}_{2}^{-}$ & 4.35E-08 & $8.03 \mathrm{E}-07$ & $3.59 \mathrm{E}-07$ & $4.02 \mathrm{E}-07$ \\
\hline $\mathrm{SO}_{4}^{2-*} \mathrm{NO}_{2}^{-}$ & $1.00 \mathrm{E}-06$ & $6.00 \mathrm{E}-06$ & $-6.42 \mathrm{E}-07$ & $2.00 \mathrm{E}-06$ \\
\hline Temperature $* \mathrm{NO}_{2}^{-}$ & 3.38E-09 & $-5.62 \mathrm{E}-09$ & $-1.02 \mathrm{E}-08$ & $-4.13 E-09$ \\
\hline $\mathrm{OH}^{-*} \mathrm{NO}_{3}^{-}$ & $2.68 \mathrm{E}-07$ & 2.32E-07 & $2.16 \mathrm{E}-07$ & 2.39E-07 \\
\hline $\mathrm{SO}_{4}{ }^{2-*} \mathrm{NO}_{3}^{-}$ & $-1.34 \mathrm{E}-06$ & $-1.17 \mathrm{E}-06$ & $-1.71 \mathrm{E}-06$ & $-1.41 \mathrm{E}-06$ \\
\hline Temperature $* \mathrm{NO}_{3}{ }^{-}$ & $-9.40 \mathrm{E}-10$ & $-1.95 \mathrm{E}-08$ & 8.93E-09 & $-3.84 \mathrm{E}-09$ \\
\hline $\mathrm{SO}_{4}{ }^{2-*} \mathrm{OH}^{-}$ & $7.12 \mathrm{E}-07$ & $5.49 \mathrm{E}-07$ & $5.18 \mathrm{E}-08$ & 4.38E-07 \\
\hline Temperature $* \mathrm{OH}^{-}$ & 8.00E-09 & 5.87E-09 & 5.91E-09 & $6.60 \mathrm{E}-09$ \\
\hline Temperature $* \mathrm{SO}_{4}{ }^{2-}$ & $8.71 \mathrm{E}-08$ & $1.39 \mathrm{E}-07$ & $1.35 \mathrm{E}-08$ & $7.98 \mathrm{E}-08$ \\
\hline $\mathrm{Al}(\mathrm{OH})_{4}{ }^{-*} \mathrm{Al}(\mathrm{OH})_{4}^{-}$ & $1.70 \mathrm{E}-05$ & $2.10 \mathrm{E}-05$ & $1.00 \mathrm{E}-05$ & $1.60 \mathrm{E}-05$ \\
\hline $\mathrm{CO}_{3}{ }^{2-*} \mathrm{CO}_{3}{ }^{2-}$ & $8.00 \mathrm{E}-06$ & $3.00 \mathrm{E}-06$ & $1.00 \mathrm{E}-05$ & $7.00 \mathrm{E}-06$ \\
\hline $\mathrm{NO}_{2}^{-} * \mathrm{NO}_{2}^{-}$ & $-7.29 \mathrm{E}-09$ & $-1.85 \mathrm{E}-07$ & $7.09 \mathrm{E}-08$ & $-4.05 \mathrm{E}-08$ \\
\hline $\mathrm{OH}^{-} * \mathrm{OH}^{-}$ & $2.97 \mathrm{E}-08$ & $8.20 \mathrm{E}-08$ & $3.91 \mathrm{E}-08$ & 5.03E-08 \\
\hline $\mathrm{SO}_{4}{ }^{2-} * \mathrm{SO}_{4}{ }^{2-}$ & $-1.00 \mathrm{E}-05$ & $-2.94 \mathrm{E}-06$ & $-5.37 \mathrm{E}-06$ & $-6.14 \mathrm{E}-06$ \\
\hline $\mathrm{NO}_{3}{ }^{-} * \mathrm{NO}_{3}{ }^{-}$ & $2.98 \mathrm{E}-07$ & $7.25 \mathrm{E}-07$ & $4.27 \mathrm{E}-08$ & $3.55 \mathrm{E}-07$ \\
\hline
\end{tabular}

Note: Shaded entries are statistically significant with at least $90 \%$ confidence.

To gain a better understanding of which of the terms in Table 6 are important for modeling the relationship of interest in this study, a data-driven approach was used. JMP's stepwise regression procedure was used to select an "optimal" model for the historical data complemented by the average Pu data from this study, where all of the second order terms were significant to at 
least the $10 \%$ level. Exhibit D.7 in Appendix D provides the results from the fitting of this model to the historical data complemented by the average Pu data from this study. The exhibit also presents the results of the fitting of this same model to the historical data complemented in turn by the Pu solubility data from this study for each of the 3 samples. Even though the $\mathrm{R}^{2}$ values for all of these fits are above $97.8 \%$, there is an indication of a statistically significant lack of fit for each of the models. This is indicated by the small p-values for the "Lack of Fit" portion of the exhibit for each of the models. Table 7 is presented to facilitate comparisons among these fitted models. Shading is used to highlight model terms that are statistically significant with at least $90 \%$ confidence. Note a main effect for a factor is shaded if the factor is involved in statistically significant interactions or quadratic effects. Since the average Pu data from this study were used to drive the stepwise regression model selection, all of the factor terms for this model are significant (shaded) in Table 7. There is, however, some consistency in the terms deemed statistically significant across these four models.

Table 7 Summary of "Optimal" Stepwise Regression Model Fit to the Historical and Current Pu Solubility Data

\begin{tabular}{|c|c|c|c|c|}
\hline $\begin{array}{c}\text { Estimated } \\
\text { Coefficient }\end{array}$ & $\begin{array}{c}\text { Sample } \\
1\end{array}$ & $\begin{array}{c}\text { Sample } \\
2\end{array}$ & $\begin{array}{c}\text { Sample } \\
3\end{array}$ & Average \\
\hline Intercept & $-4.93 \mathrm{E}-07$ & $5.31 \mathrm{E}-07$ & $-3.43 \mathrm{E}-07$ & $-1.02 \mathrm{E}-07$ \\
\hline $\mathrm{Al}(\mathrm{OH})_{4}^{-}$ & $6.05 \mathrm{E}-07$ & $1.98 \mathrm{E}-07$ & $5.10 \mathrm{E}-06$ & $2.00 \mathrm{E}-06$ \\
\hline $\mathrm{CO}_{3}^{2-}$ & $-1.50 \mathrm{E}-05$ & $-9.00 \mathrm{E}-06$ & $-2.10 \mathrm{E}-05$ & $-1.50 \mathrm{E}-05$ \\
\hline $\mathrm{NO}_{2}^{-}$ & $-1.56 \mathrm{E}-07$ & $-4.02 \mathrm{E}-07$ & $-1.53 \mathrm{E}-07$ & $-2.37 \mathrm{E}-07$ \\
\hline $\mathrm{NO}_{3}{ }^{-}$ & $7.71 \mathrm{E}-07$ & $7.86 \mathrm{E}-07$ & $7.16 \mathrm{E}-07$ & $7.58 \mathrm{E}-07$ \\
\hline $\mathrm{OH}^{-}$ & 8.37E-07 & $6.51 \mathrm{E}-07$ & 7.14E-07 & 7.34E-07 \\
\hline $\mathrm{SO}_{4}{ }^{2-}$ & 7.89E-07 & $-4.00 \mathrm{E}-06$ & $-2.00 \mathrm{E}-06$ & $-2.00 \mathrm{E}-06$ \\
\hline Temperature & $-2.72 \mathrm{E}-08$ & $-5.75 \mathrm{E}-08$ & $-2.14 \mathrm{E}-08$ & $-3.54 \mathrm{E}-08$ \\
\hline $\mathrm{CO}_{3}{ }^{2-*} \mathrm{Al}(\mathrm{OH})_{4}{ }^{-}$ & $-2.00 \mathrm{E}-06$ & $-6.28 \mathrm{E}-07$ & $-9.00 \mathrm{E}-06$ & $-4.00 \mathrm{E}-06$ \\
\hline $\mathrm{NO}_{2}{ }^{-*} \mathrm{Al}(\mathrm{OH})_{4}^{-}$ & $1.00 \mathrm{E}-06$ & $2.00 \mathrm{E}-06$ & $4.28 \mathrm{E}-07$ & $1.10 \mathrm{E}-06$ \\
\hline $\mathrm{NO}_{3}{ }^{-} * \mathrm{Al}(\mathrm{OH})_{4}^{-}$ & $-2.00 \mathrm{E}-06$ & $-1.00 \mathrm{E}-06$ & $-3.00 \mathrm{E}-06$ & $-2.00 \mathrm{E}-06$ \\
\hline $\mathrm{SO}_{4}{ }^{2-*} \mathrm{Al}(\mathrm{OH})_{4}^{-}$ & $4.60 \mathrm{E}-06$ & $1.92 \mathrm{E}-05$ & $1.49 \mathrm{E}-05$ & $1.29 \mathrm{E}-05$ \\
\hline Temperature $^{*} \mathrm{Al}(\mathrm{OH})_{4}^{-}$ & $-1.02 \mathrm{E}-07$ & $-1.08 \mathrm{E}-07$ & $-1.39 \mathrm{E}-07$ & $-1.16 \mathrm{E}-07$ \\
\hline $\mathrm{NO}_{2}{ }^{-} * \mathrm{CO}_{3}{ }^{2-}$ & $1.70 \mathrm{E}-06$ & $1.50 \mathrm{E}-06$ & $1.30 \mathrm{E}-06$ & $1.50 \mathrm{E}-06$ \\
\hline $\mathrm{NO}_{3}{ }^{-*} \mathrm{CO}_{3}{ }^{2-}$ & 9.18E-07 & $5.52 \mathrm{E}-07$ & $2.50 \mathrm{E}-06$ & $1.30 \mathrm{E}-06$ \\
\hline $\mathrm{OH}^{-} * \mathrm{CO}_{3}{ }^{2-}$ & $3.30 \mathrm{E}-06$ & $3.20 \mathrm{E}-06$ & 4.60E-06 & $3.70 \mathrm{E}-06$ \\
\hline $\mathrm{SO}_{4}{ }^{2-*} \mathrm{CO}_{3}{ }^{2-}$ & $1.18 \mathrm{E}-05$ & $5.00 \mathrm{E}-06$ & $2.01 \mathrm{E}-05$ & $1.23 \mathrm{E}-05$ \\
\hline Temperature $* \mathrm{CO}_{3}{ }^{2-}$ & $2.68 \mathrm{E}-08$ & $-3.39 \mathrm{E}-09$ & $4.45 \mathrm{E}-08$ & $2.26 \mathrm{E}-08$ \\
\hline $\mathrm{SO}_{4}{ }^{2-} * \mathrm{NO}_{3}^{-}$ & $-1.00 \mathrm{E}-06$ & $-1.00 \mathrm{E}-06$ & $-1.00 \mathrm{E}-06$ & $-1.00 \mathrm{E}-06$ \\
\hline Temperature* $\mathrm{OH}^{-}$ & $7.96 \mathrm{E}-09$ & $1.05 \mathrm{E}-08$ & $5.93 \mathrm{E}-09$ & $8.14 \mathrm{E}-09$ \\
\hline Temperature* $\mathrm{SO}_{4}{ }^{2-}$ & 4.98E-08 & $1.66 \mathrm{E}-07$ & $6.08 \mathrm{E}-08$ & $9.22 \mathrm{E}-08$ \\
\hline $\mathrm{Al}(\mathrm{OH})_{4}{ }^{-*} \mathrm{Al}(\mathrm{OH})_{4}{ }^{-}$ & $1.29 \mathrm{E}-05$ & $6.60 \mathrm{E}-06$ & $1.28 \mathrm{E}-05$ & $1.08 \mathrm{E}-05$ \\
\hline $\mathrm{CO}_{3}{ }^{2-*} \mathrm{CO}_{3}{ }^{2-}$ & $9.10 \mathrm{E}-06$ & 7.30E-06 & $1.04 \mathrm{E}-05$ & $8.90 \mathrm{E}-06$ \\
\hline
\end{tabular}

Note: Shaded entries are statistically significant with at least $90 \%$ confidence. 
Between the extremes of the simple first-order model given by equation 5 and the more complex models provided in Table 7, these results suggest the potential for a data driven approach to gain insight into the relationship of Pu solubility to the factors defined in Table 1. After the remaining two samples are taken from the 20 experimental trials for this study, the data from those samples will be combined with the sample data presented in this report and the models fitting process will be repeated.

\section{Conclusions and Recommendations}

Preliminary results from a series of small-scale experiments were used to model Pu and Am solubilities with salt concentrations and temperatures representative of the ranges expected in SRS waste tanks. A statistically designed experiment was used to prepare 20 solutions with varying salt concentrations $\left(\mathrm{OH}^{-}, \mathrm{Al}(\mathrm{OH})_{4}{ }^{-}, \mathrm{SO}_{4}{ }^{2-}, \mathrm{CO}_{3}{ }^{2-}, \mathrm{NO}_{3}{ }^{-}\right.$, and $\left.\mathrm{NO}_{2}{ }^{-}\right)$which were equilibrated at either 25 or $80^{\circ} \mathrm{C}$. Three sets of salt solutions were analyzed at nominally 1 month intervals. Analysis of the solubility data showed no time-dependence of the Pu and Am concentrations; however, the data scatter was large enough that one cannot conclude that equilibrium concentrations were reached. For this reason, the analysis of 2 additional sets of solutions prepared as part of this study is recommended.

The 3 data sets were initially used to develop first-order models for both Pu and Am solubility. Since the equilibrium concentrations may not have been reached, preliminary models were developed using the analyzed concentrations for each of the individual samples and their average to represent the solubility of each element. In this analysis, Pu solubility was found to be only a function of $\mathrm{OH}^{-}$and $\mathrm{CO}_{3}{ }^{2-}$ concentrations; Am solubility was found to be a function of $\mathrm{OH}^{-}$, $\mathrm{CO}_{3}{ }^{2-}$, and $\mathrm{NO}_{3}{ }^{-}$concentrations and temperature. These factors were statistically significant with at least $90 \%$ confidence. A comparison of the coefficients for the multiple Pu and Am models showed small changes in the values; however, the trends (sign and relative magnitude) were generally the same.

The solubility data obtained for Pu in this study were combined with historical data from the literature to develop a modified response surface model. As with the first-order model for Pu, response surface models were developed using the analyzed concentrations for each of the individual samples and their average to represent the solubility of Pu obtained in this study. Even with the sample-to-sample variation in the measurements, there was some consistency in the terms that were statistically significant across the models. Statistical methods were then used to reduce the number of model terms from 35 (the quadratic temperature term was not allowed) to 23 which were significant with at least $90 \%$ confidence. All of the salt concentrations and temperature terms were statistically significant. Even with the reduction in terms, the correlation coefficient $\left(\mathrm{R}^{2}\right)$ was still very good $(97.8 \%)$. However, with this number of terms and a limited amount of data, it is difficult to distinguish whether a term is truly significant or is overly sensitive to variations in the solubility data. With better estimates of the Pu solubility for the 20 design points, additional analysis can be used to re-evaluate the significance of the model terms and complete an evaluation of parameter sensitivity and validate the predictive performance. 


\section{References}

1. D. T. Hobbs, T. B. Edwards, and S. D. Fleischman, Solubility of Plutonium and Uranium in Alkaline Salt Solutions, Report No. WSRC-TR-93-00056, Westinghouse Savannah River Company, Aiken, SC, February 1993.

2. D. T. Hobbs and T. B. Edwards, Solubility of Plutonium in Alkaline Salt Solutions, Report No. WSRC-TR-93-00131, Westinghouse Savannah River Company, Aiken, SC, February 1993.

3. C. H. Delegard and S. A. Gallagher, Effects of Hanford High-Level Waste Components on the Solubility of Cobalt, Strontium, Neptunium, Plutonium, and Americium, Report No. RHO-RE-ST-3P, Rockwell Hanford Operations, Richland WA, October 1993.

4. V. F. Peretrukhin, S. V. Kryutchkov, V. I. Silin, and I. G. Tananaev, Determination of the Solubility of Np(IV)-(VI), Pu(III)-(VI), Am(III)-(VI), and Tc(IV), (V) Hydroxo Compounds in 0.5 - 14M NaOH Solutions, Report No. WHC-EP-0987, Westinghouse Hanford Company, Richland, WA, September 1996.

5. SAS Institute, Inc., JMP®: Statistics and Graphics Guide, Version 3.0, SAS Institute, Inc., Cary, NC, 1994.

6. Myers, R. H. and D. C. Montgomery, Response Surface Methodology - Process and Product Optimization Using Design Experiments, Second Edition, John Wiley and Sons, Inc., New York, 2002.

7. K. Q. Ye, Orthogonal Column Latin Hypercubes and Their Application in Computer Experiments, Journal of the American Statistical Association, 1998, 93, 1430-1439.

8. SAS Institute, Inc., JMP®: Statistics and Graphics Guide, Version 5.0, SAS Institute, Inc., Cary, NC, 2002.

9. C. H. Delegard, Solubility of $\mathrm{PuO}_{2} \bullet \mathrm{H}_{2} \mathrm{O}$ in Alkaline Hanford High-Level Waste Solution, Report No. RHO-RE-SA-75P, Rockwell Hanford Operations, Richland WA, May 1985.

10. Bedrock Waste Storage: Technical Progress Report, February-April, 1972, Report No. DPST-72-122-2, E. I. du Pont de Nemours \& Co., Aiken, SC, July 1972.

11. I. W. Marine, Bedrock Waste Storage: Technical Progress Report, September 1972-June 1973, Report No. DPST-73-122-1, E. I. du Pont de Nemours \& Co., Aiken, SC, October 1973. 
WSRC-TR-2004-00349

Revision 0

\section{Appendix A Tables and Exhibits Supporting the Development of the Test Matrix}

Table A1. Historical Pu Solubility Data Based Upon Previous Studies

\begin{tabular}{|c|c|c|c|c|c|c|c|c|c|}
\hline Data Set & $\overline{\mathrm{Al}(\mathrm{OH})_{4}}$ & $\mathrm{CO}_{3}{ }^{2-}$ & $\mathrm{NO}_{2}^{-}$ & $\mathrm{NO}_{3}^{-}$ & $\mathrm{OH}^{-}$ & $\mathrm{SO}_{4}{ }^{2-}$ & Temperature & $\begin{array}{c}\mathrm{Pu} \\
\text { Solubility }\end{array}$ & $\begin{array}{c}\text { Constraints } \\
\text { Met }\end{array}$ \\
\hline & (M) & (M) & (M) & $(\mathrm{M})$ & (M) & (M) & (M) & $(\mathrm{M})$ & \\
\hline 11 & 0 & 0 & 0 & 4 & 4 & 0 & 22 & $1.26 \mathrm{E}-06$ & yes \\
\hline 1 & 0 & 0 & 0 & 1 & 5 & 0 & 22 & $1.34 \mathrm{E}-06$ & yes \\
\hline 1 & 0 & 0 & 0 & 1.5 & 5 & 0 & 22 & $1.58 \mathrm{E}-06$ & yes \\
\hline 1 & 0 & 0 & 0 & 2 & 5 & 0 & 22 & $1.68 \mathrm{E}-06$ & yes \\
\hline 1 & 0 & 0 & 0 & 3 & 5 & 0 & 22 & $2.48 \mathrm{E}-06$ & yes \\
\hline 1 & 0 & 0 & 0 & 3 & 5 & 0 & 22 & $1.92 \mathrm{E}-06$ & yes \\
\hline 1 & 0 & 0 & 0 & 4 & 5 & 0 & 22 & $3.00 \mathrm{E}-06$ & yes \\
\hline 1 & 0 & 0 & 0 & 2 & 6 & 0 & 22 & $4.74 \mathrm{E}-06$ & yes \\
\hline 1 & 0 & 0 & 0 & 1 & 7 & 0 & 22 & $7.93 \mathrm{E}-06$ & yes \\
\hline 1 & 0 & 0 & 4 & 0 & 4 & 0 & 22 & $4.00 \mathrm{E}-07$ & yes \\
\hline 1 & 0 & 0 & 1 & 0 & 5 & 0 & 22 & $1.17 \mathrm{E}-06$ & yes \\
\hline 1 & 0 & 0 & 1.5 & 0 & 5 & 0 & 22 & $9.20 \mathrm{E}-07$ & yes \\
\hline 1 & 0 & 0 & 2 & 0 & 5 & 0 & 22 & $5.50 \mathrm{E}-07$ & yes \\
\hline 1 & 0 & 0 & 3 & 0 & 5 & 0 & 22 & $1.12 \mathrm{E}-06$ & yes \\
\hline 1 & 0 & 0 & 3 & 0 & 5 & 0 & 22 & $7.00 \mathrm{E}-07$ & yes \\
\hline 1 & 0 & 0 & 4 & 0 & 5 & 0 & 22 & $7.80 \mathrm{E}-07$ & yes \\
\hline 1 & 0 & 0 & 2 & 0 & 6 & 0 & 22 & $5.54 \mathrm{E}-06$ & yes \\
\hline 1 & 0 & 0 & 1 & 0 & 7 & 0 & 22 & $5.09 \mathrm{E}-06$ & yes \\
\hline 1 & 0 & 0 & 1 & 1 & 1 & 0 & 22 & $3.00 \mathrm{E}-08$ & yes \\
\hline 1 & 0 & 0 & 1 & 1 & 2 & 0 & 22 & $1.20 \mathrm{E}-07$ & yes \\
\hline 1 & 0 & 0 & 1 & 1 & 3 & 0 & 22 & $3.20 \mathrm{E}-07$ & yes \\
\hline 1 & 0 & 0 & 1 & 1 & 4 & 0 & 22 & $7.70 \mathrm{E}-07$ & yes \\
\hline 1 & 0 & 0 & 0.25 & 0.25 & 5 & 0 & 22 & $2.01 \mathrm{E}-06$ & yes \\
\hline 1 & 0 & 0 & 0.5 & 0.5 & 5 & 0 & 22 & $2.85 \mathrm{E}-06$ & yes \\
\hline 1 & 0 & 0 & 1 & 1 & 5 & 0 & 22 & $3.86 \mathrm{E}-06$ & yes \\
\hline 1 & 0 & 0 & 1 & 1 & 5 & 0 & 22 & $2.09 \mathrm{E}-06$ & yes \\
\hline 1 & 0 & 0 & 1.5 & 1.5 & 5 & 0 & 22 & $6.49 \mathrm{E}-06$ & yes \\
\hline 1 & 0 & 0 & 2 & 2 & 5 & 0 & 22 & $8.71 \mathrm{E}-06$ & yes \\
\hline 1 & 0 & 0 & 2.5 & 2.5 & 5 & 0 & 22 & $8.47 \mathrm{E}-06$ & yes \\
\hline 1 & 0 & 0 & 3 & 3 & 5 & 0 & 22 & $1.48 \mathrm{E}-05$ & yes \\
\hline 1 & 0 & 0 & 3 & 3 & 5 & 0 & 22 & $1.48 \mathrm{E}-05$ & yes \\
\hline 1 & 0 & 0 & 1 & 1 & 6 & 0 & 22 & $4.60 \mathrm{E}-06$ & yes \\
\hline 1 & 0 & 0 & 2.5 & 2.5 & 6 & 0 & 22 & $3.82 \mathrm{E}-05$ & yes \\
\hline 1 & 0 & 0 & 1 & 1 & 7 & 0 & 22 & $1.03 \mathrm{E}-05$ & yes \\
\hline 1 & 0 & 0 & 2 & 2 & 7 & 0 & 22 & $9.41 \mathrm{E}-06$ & yes \\
\hline 1 & 0 & 0 & 1 & 1 & 8 & 0 & 22 & $2.99 \mathrm{E}-05$ & yes \\
\hline 1 & 0 & 0 & 1.5 & 1.5 & 8 & 0 & 22 & $8.44 \mathrm{E}-05$ & yes \\
\hline 1 & 0 & 0 & 1 & 1 & 9 & 0 & 22 & $1.07 \mathrm{E}-04$ & yes \\
\hline 1 & 0 & 0 & 1 & 1 & 9 & 0 & 22 & $6.67 \mathrm{E}-05$ & yes \\
\hline 1 & 0 & 0 & 0.5 & 0.5 & 10 & 0 & 22 & $2.69 \mathrm{E}-04$ & yes \\
\hline 1 & 0 & 0 & 1 & 1 & 10 & 0 & 22 & $1.45 \mathrm{E}-04$ & yes \\
\hline 1 & 0 & 0 & 0.25 & 0.25 & 10.5 & 0 & 22 & $1.84 \mathrm{E}-04$ & yes \\
\hline
\end{tabular}

1 Dataset number 1 is from reference [9]. 
WSRC-TR-2004-00349

Revision 0

Table A1. Historical Pu Solubility Data Based Upon Previous Studies (continued)

\begin{tabular}{|c|c|c|c|c|c|c|c|c|c|}
\hline 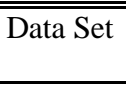 & $\mathrm{Al}(\mathrm{OH})_{4}^{-}$ & $\mathrm{COO}_{3}^{2-}$ & $\mathrm{NO}_{2}^{-}$ & $\mathrm{NO}_{3}^{-}$ & $\mathrm{OH}^{-}$ & $\mathrm{ISO}_{4}{ }^{2-}$ & Temperature & $\begin{array}{c}\mathrm{Pu} \\
\text { Solubility }\end{array}$ & $\begin{array}{c}\text { Constraints } \\
\text { Met }\end{array}$ \\
\hline & (M) & (M) & (M) & (M) & (M) & (M) & $\left({ }^{\circ} \mathrm{C}\right)$ & $(\mathrm{M})$ & \\
\hline $2^{2}$ & 0.00005 & 0.025 & 1 & 2 & 4 & 0.005 & 22 & $4.58 \mathrm{E}-06$ & yes \\
\hline 2 & 0.00005 & 0.025 & 1 & 2 & 1 & 0.005 & 22 & $1.04 \mathrm{E}-06$ & yes \\
\hline 2 & 0.00005 & 0.025 & 1 & $2 \mathrm{E}-08$ & 4 & 0.005 & 22 & $2.07 \mathrm{E}-06$ & no \\
\hline 2 & 0.00005 & 0.025 & 1 & 2E-08 & 1 & 0.005 & 22 & $4.80 \mathrm{E}-07$ & no \\
\hline 2 & 0.5 & 0.025 & 1 & 2 & 2 & 0.005 & 22 & $3.39 \mathrm{E}-06$ & yes \\
\hline 2 & $5.00 \mathrm{E}-09$ & 0.025 & 1 & 2 & 2 & 0.005 & 22 & $1.29 \mathrm{E}-06$ & yes \\
\hline 2 & 0.5 & 0.025 & 1 & $2 \mathrm{E}-08$ & 2 & 0.005 & 22 & $1.24 \mathrm{E}-06$ & no \\
\hline 2 & $5.00 \mathrm{E}-09$ & 0.025 & 1 & $2 \mathrm{E}-08$ & 2 & 0.005 & 22 & $5.70 \mathrm{E}-07$ & yes \\
\hline 2 & 0.5 & 0.025 & 1 & 0.0002 & 4 & 0.005 & 22 & $3.31 \mathrm{E}-06$ & no \\
\hline 2 & $5.00 \mathrm{E}-09$ & 0.025 & 1 & 0.0002 & 4 & 0.005 & 22 & $2.34 \mathrm{E}-06$ & yes \\
\hline 2 & 0.5 & 0.025 & 1 & 0.0002 & 1 & 0.005 & 22 & $1.00 \mathrm{E}-06$ & no \\
\hline 2 & $5.00 \mathrm{E}-09$ & 0.025 & 1 & 0.0002 & 1 & 0.005 & 22 & $3.70 \mathrm{E}-07$ & yes \\
\hline 2 & 0.00005 & 0.025 & 1 & 0.0002 & 2 & 0.005 & 22 & $5.70 \mathrm{E}-07$ & yes \\
\hline 2 & 0.00005 & 0.025 & 1 & 0.0002 & 2 & 0.005 & 22 & $5.10 \mathrm{E}-07$ & yes \\
\hline 2 & 0.00005 & 0.025 & 1 & 0.0002 & 2 & 0.005 & 22 & $7.40 \mathrm{E}-07$ & yes \\
\hline $3^{3}$ & 0.05 & 0.02 & 2 & 1 & 2 & 0.4 & 60 & $1.58 \mathrm{E}-06$ & yes \\
\hline 3 & 0.19 & 0.16 & 1.05 & 2.5 & 1.25 & 0.21 & 60 & $2.70 \mathrm{E}-07$ & yes \\
\hline 3 & 0.19 & 0.16 & 1.05 & 2.5 & 1.25 & 0.21 & 60 & $2.90 \mathrm{E}-07$ & yes \\
\hline 3 & 0.19 & 0.16 & 1.05 & 2.5 & 1.25 & 0.21 & 25 & $5.00 \mathrm{E}-07$ & yes \\
\hline 3 & 0.33 & 0.3 & 0.1 & 4 & 0.5 & 0.02 & 25 & $1.22 \mathrm{E}-06$ & no \\
\hline 3 & 0.363 & 0.02 & 2 & 4.96 & 0.75 & 0.02 & 25 & $3.50 \mathrm{E}-07$ & no \\
\hline 3 & 0.33 & 0.02 & 0.1 & 1 & 2 & 0.4 & 25 & $3.07 \mathrm{E}-06$ & yes \\
\hline 3 & 0.33 & 0.3 & 2 & 1 & 2 & 0.02 & 25 & $1.30 \mathrm{E}-06$ & yes \\
\hline 3 & 0.05 & 0.3 & 0.1 & 1 & 2 & 0.02 & 60 & $5.30 \mathrm{E}-07$ & yes \\
\hline 3 & 0.33 & 0.02 & 2 & 4 & 0.5 & 0.4 & 25 & $2.60 \mathrm{E}-07$ & no \\
\hline 3 & 0.33 & 0.02 & 0.1 & 4 & 2 & 0.02 & 60 & $6.70 \mathrm{E}-07$ & yes \\
\hline 3 & 0.05 & 0.02 & 0.1 & 1 & 0.5 & 0.02 & 25 & $7.00 \mathrm{E}-08$ & yes \\
\hline 3 & 0.19 & 0.16 & 1.05 & 2.5 & 1.25 & 0.21 & 25 & $4.30 \mathrm{E}-07$ & yes \\
\hline 3 & 0.23 & 0.21 & 1.4 & 2.8 & 1.4 & 0.28 & 60 & $6.70 \mathrm{E}-07$ & yes \\
\hline 3 & 0.05 & 0.3 & 2 & 4 & 0.5 & 0.02 & 60 & $6.10 \mathrm{E}-07$ & yes \\
\hline 3 & 0.05 & 0.02 & 0.1 & 4 & 0.5 & 0.4 & 60 & $8.00 \mathrm{E}-08$ & yes \\
\hline 3 & 0.33 & 0.02 & 2 & 1 & 0.5 & 0.02 & 60 & $7.00 \mathrm{E}-08$ & no \\
\hline 3 & 0.5 & 0.3 & 2 & 1 & 0.5 & 0.4 & 25 & $1.80 \mathrm{E}-07$ & no \\
\hline 3 & 0.33 & 0.3 & 0.1 & 1 & 0.5 & 0.4 & 60 & $5.30 \mathrm{E}-07$ & no \\
\hline 3 & 0.05 & 0.3 & 0.1 & 4 & 2 & 0.4 & 25 & $4.09 \mathrm{E}-06$ & yes \\
\hline 3 & 0.33 & 0.3 & 0.1 & 1 & 0.5 & 0.4 & 22 & $1.20 \mathrm{E}-07$ & no \\
\hline $4^{4}$ & 0 & 0 & 0 & 1 & 4.1E-07 & 0 & 29.6 & $1.30 \mathrm{E}-07$ & no \\
\hline 4 & 0 & 0 & 0 & 1 & $7.2 \mathrm{E}-07$ & 0 & 29.6 & $1.40 \mathrm{E}-07$ & no \\
\hline 4 & 0 & 0 & 0 & 1 & $1.05 \mathrm{E}-06$ & 0 & 29.6 & $5.00 \mathrm{E}-07$ & no \\
\hline 4 & 0 & 0 & 0 & 1 & $6.17 \mathrm{E}-06$ & 0 & 29.6 & $1.00 \mathrm{E}-07$ & no \\
\hline 4 & 0 & 0 & 0 & 1 & $1.23 \mathrm{E}-05$ & 0 & 29.6 & $8.00 \mathrm{E}-08$ & no \\
\hline 4 & 0 & 0 & 0 & 1 & $1.74 \mathrm{E}-05$ & 0 & 29.6 & $1.40 \mathrm{E}-07$ & no \\
\hline 4 & 0 & 0 & 0 & 1 & $1.74 \mathrm{E}-05$ & 0 & 29.6 & $1.10 \mathrm{E}-07$ & no \\
\hline 4 & 0 & 0 & 0 & 1 & $2.51 \mathrm{E}-05$ & 0 & 29.6 & $7.00 \mathrm{E}-08$ & no \\
\hline 4 & 0 & 0 & 0 & 1 & 0.000038 & 0 & 29.6 & $4.00 \mathrm{E}-07$ & no \\
\hline
\end{tabular}

2 Dataset number 2 is from reference [3].

3 Dataset number 3 is from reference [1].

4 Dataset number 4 is from reference [10]. 
WSRC-TR-2004-00349

Revision 0

Table A1. Historical Pu Solubility Data Based Upon Previous Studies (continued)

\begin{tabular}{|c|c|c|c|c|c|c|c|c|c|}
\hline Data Set & $\mathrm{Al}(\mathrm{OH})_{4}^{-}$ & $\mathrm{CO}_{3}{ }^{2-}$ & $\mathrm{NO}_{2}^{-}$ & $\mathrm{NO}_{3}{ }^{-}$ & $\mathrm{OH}^{-}$ & $\mathrm{SO}_{4}{ }^{2-}$ & Temperature & $\begin{array}{c}\mathrm{Pu} \\
\text { Solubility }\end{array}$ & $\begin{array}{c}\text { Constraints } \\
\text { Met }\end{array}$ \\
\hline & (M) & (M) & (M) & (M) & (M) & (M) & $\left({ }^{\circ} \mathrm{C}\right)$ & (M) & \\
\hline 4 & 0 & 0 & 0 & 1 & $3.98 \mathrm{E}-05$ & 0 & 29.6 & $1.70 \mathrm{E}-07$ & no \\
\hline 4 & 0 & 0 & 0 & 1 & $5.37 \mathrm{E}-05$ & 0 & 29.6 & $4.00 \mathrm{E}-08$ & no \\
\hline 4 & 0 & 0 & 0 & 1 & $7.94 \mathrm{E}-05$ & 0 & 29.6 & $3.00 \mathrm{E}-07$ & no \\
\hline 4 & 0 & 0 & 0 & 1 & 0.000148 & 0 & 29.6 & $1.90 \mathrm{E}-07$ & no \\
\hline 4 & 0 & 0 & 0 & 1 & 0.000339 & 0 & 29.6 & $2.20 \mathrm{E}-07$ & no \\
\hline 4 & 0 & 0 & 0 & 1 & 0.000347 & 0 & 29.6 & $3.00 \mathrm{E}-08$ & no \\
\hline 4 & 0 & 0 & 0 & 1 & 0.000468 & 0 & 29.6 & $4.00 \mathrm{E}-08$ & no \\
\hline 4 & 0 & 0 & 0 & 1 & 0.000617 & 0 & 29.6 & $6.00 \mathrm{E}-08$ & no \\
\hline 4 & 0 & 0 & 0 & 1 & 0.000741 & 0 & 29.6 & $2.00 \mathrm{E}-08$ & no \\
\hline 4 & 0 & 0 & 0 & 1 & 0.00275 & 0 & 29.6 & $8.00 \mathrm{E}-08$ & no \\
\hline 4 & 0 & 0 & 0 & 1 & 0.00724 & 0 & 29.6 & 3.70E-07 & no \\
\hline 4 & 0 & 0 & 0 & 1 & 0.00741 & 0 & 29.6 & $7.00 \mathrm{E}-08$ & no \\
\hline 4 & 0 & 0 & 0 & 1 & 0.0102 & 0 & 29.6 & $1.50 \mathrm{E}-07$ & no \\
\hline 4 & 0 & 0 & 0 & 1 & 0.0132 & 0 & 29.6 & $1.40 \mathrm{E}-07$ & no \\
\hline 4 & 0 & 0 & 0 & 1 & 0.0132 & 0 & 29.6 & $1.60 \mathrm{E}-07$ & no \\
\hline 4 & 0 & 0 & 0 & 1 & 0.0427 & 0 & 29.6 & $2.00 \mathrm{E}-07$ & no \\
\hline 4 & 0 & 0 & 0 & 1 & 0.0759 & 0 & 29.6 & $7.00 \mathrm{E}-07$ & no \\
\hline 4 & 0 & 0 & 0 & 1 & 0.0871 & 0 & 29.6 & $1.50 \mathrm{E}-07$ & no \\
\hline 4 & 0 & 0 & 0 & 1 & 0.0891 & 0 & 29.6 & $1.00 \mathrm{E}-07$ & no \\
\hline 4 & 0 & 0 & 0 & 1 & 0.102 & 0 & 29.6 & $2.00 \mathrm{E}-08$ & no \\
\hline 4 & 0 & 0 & 0 & 1 & 0.11 & 0 & 29.6 & $3.30 \mathrm{E}-07$ & no \\
\hline 4 & 0 & 0 & 0 & 1 & 0.288 & 0 & 29.6 & $7.00 \mathrm{E}-08$ & no \\
\hline 4 & 0 & 0 & 0 & 1 & 0.479 & 0 & 29.6 & $3.00 \mathrm{E}-08$ & yes \\
\hline 4 & 0 & 0 & 0 & 1 & 0.501 & 0 & 29.6 & $1.00 \mathrm{E}-07$ & yes \\
\hline 4 & 0 & 0 & 0 & 1 & 0.575 & 0 & 29.6 & $4.00 \mathrm{E}-08$ & yes \\
\hline 4 & 0 & 0 & 0 & 1 & 0.589 & 0 & 29.6 & $1.90 \mathrm{E}-07$ & yes \\
\hline 4 & 0 & 0 & 0 & 1 & 0.646 & 0 & 29.6 & $5.00 \mathrm{E}-08$ & yes \\
\hline $5^{5}$ & 0 & 0 & 0.125 & 0.875 & 2.6E-07 & 0 & 30.4 & 4.00E-08 & no \\
\hline 5 & 0 & 0 & 0.125 & 0.875 & $5 \mathrm{E}-07$ & 0 & 30.4 & $9.30 \mathrm{E}-09$ & no \\
\hline 5 & 0 & 0 & 0.125 & 0.875 & $2.69 \mathrm{E}-06$ & 0 & 30.4 & $6.10 \mathrm{E}-09$ & no \\
\hline 5 & 0 & 0 & 0.125 & 0.875 & 0.00724 & 0 & 30.4 & $4.50 \mathrm{E}-09$ & no \\
\hline 5 & 0 & 0 & 0.125 & 0.875 & 0.117 & 0 & 30.4 & $5.20 \mathrm{E}-09$ & no \\
\hline 5 & 0 & 0 & 0.125 & 0.875 & 0.224 & 0 & 30.4 & $5.00 \mathrm{E}-08$ & no \\
\hline 5 & 0 & 0 & 0.5 & 3.5 & 2E-07 & 0 & 30.4 & $3.90 \mathrm{E}-09$ & no \\
\hline 5 & 0 & 0 & 0.5 & 3.5 & $8.91 \mathrm{E}-06$ & 0 & 30.4 & $3.00 \mathrm{E}-08$ & no \\
\hline 5 & 0 & 0 & 0.5 & 3.5 & 0.000741 & 0 & 30.4 & $3.70 \mathrm{E}-09$ & no \\
\hline 5 & 0 & 0 & 0.5 & 3.5 & 0.0117 & 0 & 30.4 & $1.80 \mathrm{E}-08$ & no \\
\hline 5 & 0 & 0 & 0.5 & 3.5 & 0.166 & 0 & 30.4 & $2.00 \mathrm{E}-08$ & no \\
\hline $6^{6}$ & 0.33 & 0.3 & 0.1 & 1 & 0.051 & 0.4 & 22 & $1.24 \mathrm{E}-06$ & no \\
\hline 6 & 0.33 & 0.3 & 0.1 & 1 & 0.051 & 0.4 & 22 & $1.67 \mathrm{E}-06$ & no \\
\hline
\end{tabular}

5 Dataset number 5 is from reference [11].

6 Dataset number 6 is from reference [1]. 
WSRC-TR-2004-00349

Revision 0

Table A.2 Additional Set of Selective Candidate Points

\begin{tabular}{||c|c|c|c|c|c|c||}
\hline \hline $\mathrm{Al}(\mathrm{OH})_{4}^{-}$ & $\mathrm{CO}_{3}^{2-}$ & $\mathrm{NO}_{2}^{-}$ & $\mathrm{NO}_{3}^{-}$ & $\mathrm{OH}^{-}$ & $\mathrm{SO}_{4}^{2-}$ & Temperature \\
\hline$(\mathrm{M})$ & $(\mathrm{M})$ & $(\mathrm{M})$ & $(\mathrm{M})$ & $(\mathrm{M})$ & $(\mathrm{M})$ & $\left({ }^{\circ} \mathrm{C}\right)$ \\
\hline & & & & & & \\
\hline 0.001 & 0.001 & 0.1 & 0.1 & 15 & 0.001 & 25 \\
\hline 0.001 & 0.001 & 0.1 & 0.1 & 15 & 0.001 & 80 \\
\hline 0.001 & 0.001 & 0.1 & 0.1 & 12 & 0.01 & 25 \\
\hline 0.001 & 0.01 & 0.1 & 0.1 & 12 & 0.001 & 25 \\
\hline 0.01 & 0.001 & 0.1 & 0.1 & 12 & 0.001 & 25 \\
\hline 0.001 & 0.01 & 0.1 & 0.1 & 12 & 0.01 & 25 \\
\hline 0.01 & 0.001 & 0.1 & 0.1 & 12 & 0.01 & 25 \\
\hline 0.01 & 0.01 & 0.1 & 0.1 & 12 & 0.001 & 25 \\
\hline 0.01 & 0.01 & 0.1 & 0.1 & 12 & 0.01 & 25 \\
\hline 0.001 & 0.001 & 0.1 & 0.1 & 12 & 0.01 & 80 \\
\hline 0.001 & 0.01 & 0.1 & 0.1 & 12 & 0.001 & 80 \\
\hline 0.01 & 0.001 & 0.1 & 0.1 & 12 & 0.001 & 80 \\
\hline 0.001 & 0.01 & 0.1 & 0.1 & 12 & 0.01 & 80 \\
\hline 0.01 & 0.001 & 0.1 & 0.1 & 12 & 0.01 & 80 \\
\hline 0.01 & 0.01 & 0.1 & 0.1 & 12 & 0.001 & 80 \\
\hline 0.01 & 0.01 & 0.1 & 0.1 & 12 & 0.01 & 80 \\
\hline 0.1 & 0.01 & 0.1 & 0.1 & 9 & 0.01 & 25 \\
\hline 0.01 & 0.1 & 0.1 & 0.1 & 9 & 0.01 & 25 \\
\hline 0.1 & 0.1 & 0.1 & 0.1 & 9 & 0.01 & 25 \\
\hline 0.1 & 0.01 & 0.1 & 0.1 & 9 & 0.01 & 80 \\
\hline 0.01 & 0.1 & 0.1 & 0.1 & 9 & 0.01 & 80 \\
\hline 0.1 & 0.1 & 0.1 & 0.1 & 9 & 0.01 & 80 \\
\hline
\end{tabular}

Table A.3 Initial Set of 8 Design Points

\begin{tabular}{||c|c|c|c|c|c|c|c||}
\hline \hline Type of Point & $\mathrm{Al}(\mathrm{OH})_{4}^{-}$ & $\mathrm{CO}_{3}{ }^{2-}$ & $\mathrm{NO}_{2}^{-}$ & $\mathrm{NO}_{3}^{-}$ & $\mathrm{OH}^{-}$ & $\mathrm{SO}_{4}{ }^{2-}$ & Temperature \\
\hline & $(\mathrm{M})$ & $(\mathrm{M})$ & $(\mathrm{M})$ & $(\mathrm{M})$ & $(\mathrm{M})$ & $(\mathrm{M})$ & $\left({ }^{\circ} \mathrm{C}\right)$ \\
\hline & & & & & & & \\
\hline Modified OLH & 0.74057 & 0.949663 & 0.168605 & 2.501163 & 1.290783 & 0.180872 & 25 \\
\hline Modified OLH & 0.031278 & 0.072562 & 3.415891 & 3.644574 & 0.453583 & 0.107376 & 25 \\
\hline Modified OLH & 0.049969 & 0.825756 & 0.794186 & 0.25 & 2.069833 & 0.46712 & 25 \\
\hline Modified OLH & 0.132317 & 0.887709 & 1.266279 & 4.879457 & 0.872183 & 0.010369 & 85 \\
\hline Modified OLH & 0.756058 & 0.221709 & 0.628295 & 2.98876 & 2.895417 & 0.482593 & 85 \\
\hline Modified OLH & 0.113337 & 0.362678 & 5.428295 & 0.625969 & 1.77915 & 0.120932 & 85 \\
\hline Modified OLH & 0.024584 & 0.012616 & 0.145349 & 0.159302 & 2.627963 & 0.084167 & 85 \\
\hline Special Design Point & 0.001 & 0.001 & 0.1 & 0.1 & 15 & 0.001 & 25 \\
\hline
\end{tabular}


WSRC-TR-2004-00349

Revision 0

Exhibit A.1 Correlations and Scatterplot Matrix for OLH Candidate Design Points

Multivariate
Correlations
\begin{tabular}{|l|c|c|c|c|c|c|c||}
\hline & $\mathrm{Al}(\mathrm{OH})_{4}{ }^{-}$ & $\mathrm{CO}_{3}{ }^{2-}$ & $\mathrm{NO}_{2}{ }^{-}$ & $\mathrm{NO}_{3}{ }^{-}$ & $\mathrm{OH}^{-}$ & $\mathrm{SO}_{4}{ }^{2-}$ & Temperature \\
\hline $\mathrm{Al}(\mathrm{OH})_{4}{ }^{-}$ & 1.0000 & -0.0740 & 0.1591 & 0.5231 & -0.1779 & -0.0340 & -0.0000 \\
\hline $\mathrm{CO}_{3}{ }^{--}$ & -0.0740 & 1.0000 & -0.2093 & -0.1408 & 0.0311 & -0.0041 & -0.0000 \\
\hline $\mathrm{NO}_{2}{ }^{-}$ & 0.1591 & -0.2093 & 1.0000 & 0.3091 & -0.2249 & -0.1020 & -0.0000 \\
\hline $\mathrm{NO}_{3}{ }^{-}$ & 0.5231 & -0.1408 & 0.3091 & 1.0000 & -0.4179 & -0.0485 & 0.0000 \\
\hline $\mathrm{OH}^{-}$ & -0.1779 & 0.0311 & -0.2249 & -0.4179 & 1.0000 & -0.1424 & 0.0000 \\
\hline $\mathrm{SO}_{4}{ }^{2-}$ & -0.0340 & -0.0041 & -0.1020 & -0.0485 & -0.1424 & 1.0000 & -0.0000 \\
\hline$T^{-}$ & -0.0000 & -0.0000 & -0.0000 & 0.0000 & 0.0000 & -0.0000 & 1.0000 \\
\hline
\end{tabular}

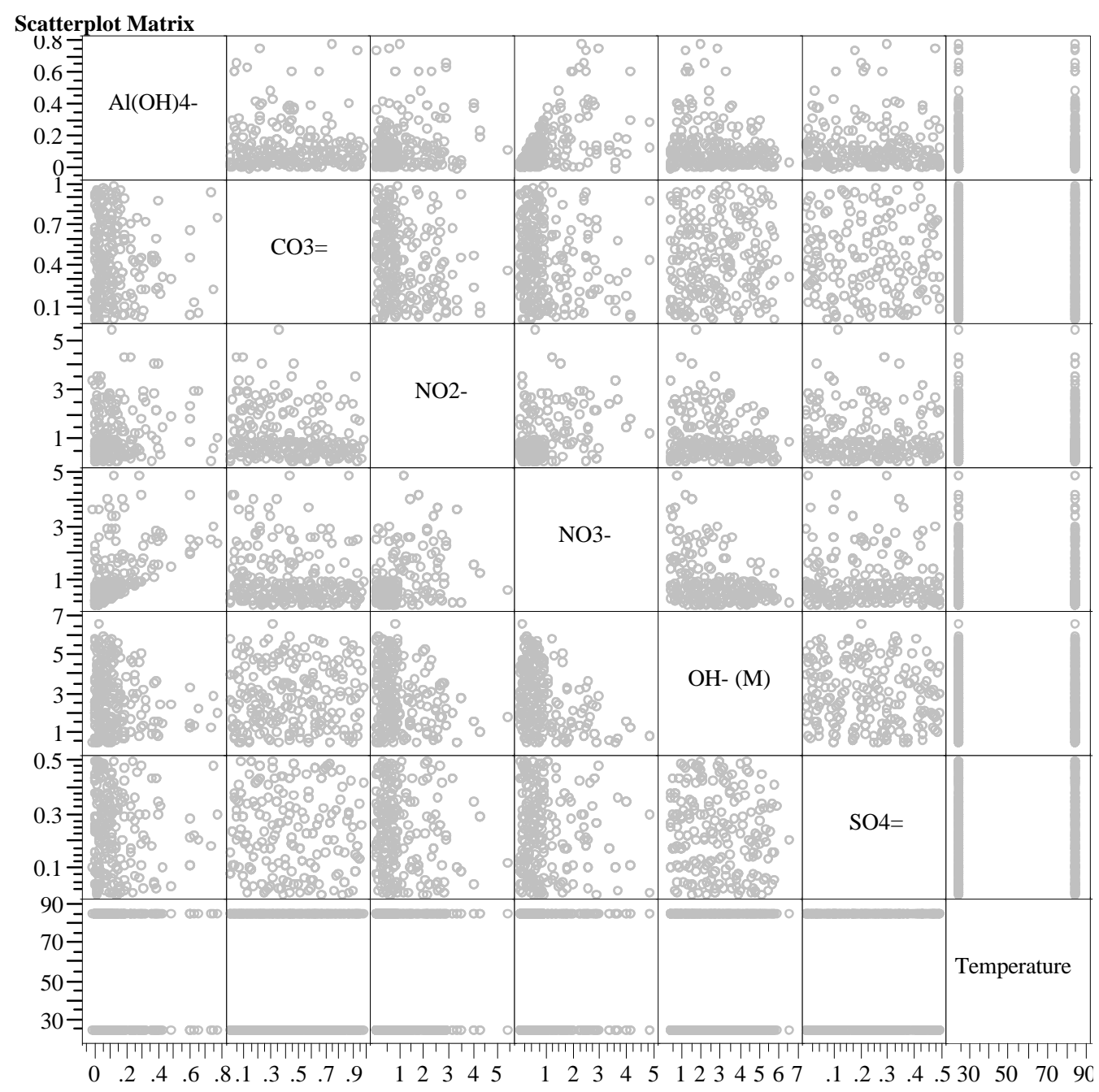


WSRC-TR-2004-00349

Revision 0

Exhibit A.2 Information Generated by the D-Optimality Routine in Selecting 8 Design Points for Am Solubility Investigation

\begin{tabular}{llc} 
N Desired & 8 \\
N Random & 5 & \\
K Value & 3 & \\
Trips & 1000 \\
& & \\
N & 8 & ----- Ready ------ \\
Trips & 1000 & \\
\multicolumn{2}{c}{ Best Design } \\
D-efficiency & 46.4267 \\
A-efficiency & 25.1801 \\
G-efficiency & 73.8521 \\
AvgPredSE & & 0.9047 \\
N & 8.0000 \\
Correlations & \\
\end{tabular}

\begin{tabular}{|c|c|c|c|c|c|c|c|c|}
\hline Corr & Intercept & $\mathrm{Al}(\mathrm{OH})_{4}^{-}$ & $\mathrm{CO}_{3}{ }^{2-}$ & $\mathrm{NO}_{2}^{-}$ & $\mathrm{NO}_{3}^{-}$ & $\mathrm{OH}^{-}$ & $\mathrm{SO}_{4}{ }^{2-}$ & Temperature \\
\hline Intercept & 1 & 0.1032 & 0.3756 & 0.6695 & 0.378 & 0.8462 & 0.3972 & 0.1782 \\
\hline $\mathrm{Al}(\mathrm{OH})_{4}^{-}$ & 0.1032 & 1 & -0.1446 & 0.2242 & -0.4084 & -0.1067 & -0.5036 & -0.1666 \\
\hline $\mathrm{CO}_{3}{ }^{2-}$ & 0.3756 & -0.1446 & 1 & 0.2425 & -0.0578 & 0.4478 & 0.0538 & 0.2962 \\
\hline $\mathrm{NO}_{2}^{-}$ & 0.6695 & 0.2242 & 0.2425 & 1 & 0.0459 & 0.4493 & 0.1429 & -0.0289 \\
\hline $\mathrm{NO}_{3}^{-}$ & 0.378 & -0.4084 & -0.0578 & 0.0459 & 1 & 0.4285 & 0.4506 & 0.0412 \\
\hline $\mathrm{OH}^{-}$ & 0.8462 & -0.1067 & 0.4478 & 0.4493 & 0.4285 & 1 & 0.4103 & 0.3316 \\
\hline $\mathrm{SO}_{4}{ }^{2-}$ & 0.3972 & -0.5036 & 0.0538 & 0.1429 & 0.4506 & 0.4103 & 1 & 0.1649 \\
\hline Temperature & 0.1782 & -0.1666 & 0.2962 & -0.0289 & 0.0412 & 0.3316 & 0.1649 & 1 \\
\hline
\end{tabular}


WSRC-TR-2004-00349

Revision 0

Exhibit A.3 Information Generated by the D-Optimality Routine in Selecting Full Set of Design Points for Pu Solubility Investigation

\begin{tabular}{llr} 
Optimal Design Controls \\
N Desired & 91 \\
N Random & 18 & \\
K Value & 3 & \\
Trips & 1000 & \\
& & \\
N & 91 & ----- Ready ------ \\
Trips & 1000 & \\
\multicolumn{2}{c}{ Best Design } \\
D-efficiency & \\
A-efficiency & 4.3781 \\
G-efficiency & 0.4286 \\
AvgPredSE & 24.3801 \\
N & 1.1516 \\
\end{tabular}


WSRC-TR-2004-00349

Revision 0

Exhibit A.3 Information Generated by the D-Optimality Routine in Selecting Full Set of Design Points for Pu Solubility Investigation (continued)

Correlations of Model Terms

\begin{tabular}{|c|c|c|c|c|c|c|c|c|c|c|c|c|c|c|c|c|c|c|c|c|c|c|c|c|c|c|c|c|c|c|c|c|c|c|c|}
\hline & (1) & (2) & (3) & (4) & (5) & (6) & (7) & (8) & (9) & (10) & (11) & (12) & (13) & (14) & (15) & (16) & (17) & (18) & (19) & (20) & (21) & (22) & (23) & (24) & (25) & (26) & (27) & (28) & (29) & (30) & (31) & (32) & (33) & (34) & (35) \\
\hline (1) Intercept & 1.000 & 0.725 & 0.376 & 0.395 & 0.305 & \begin{tabular}{|l|l|}
0.921 \\
\end{tabular} & $\mid$\begin{tabular}{|c|}
$\mid-0.115$ \\
\end{tabular} & $0.143 \mid$ & \begin{tabular}{|l|l|}
-0.499 \\
\end{tabular} & 0.532 & 0.320 & 0.347 & 0.138 & -0.050 & 0.356 & $|-0.084|$ & 0.224 & 0.068 & 0.749 & 0.114 & 0.151 & 0.030 & 0.148 & \begin{tabular}{|l|l|} 
& -0.041 \\
\end{tabular} & \begin{tabular}{l|l}
0.088 \\
\end{tabular} & -0.107 & 0.103 & -0.178 & 0.141 & 0.095 & 0.189 & \begin{tabular}{|l|}
0.162 \\
\end{tabular} & -0.130 & 0.006 & 0.00 \\
\hline (2) $\mathrm{Al}(\mathrm{OH})_{4}^{4}$ & 1.725 & 1.000 & 0.042 & 0.163 & -0.038 & 0.667 & -0.418 & $|-0.045|$ & $|-0.483|$ & 0.705 & 0.330 & 0.554 & 0.065 & -0.194 & 0.491 & $\mid-0.394$ & 0.003 & -0.092 & 0.955 & -0.253 & -0.080 & -0.255 & -0.066 & 0.007 & -0.228 & $|-0.327|$ & \begin{tabular}{|l|} 
\\
\end{tabular} & -0.279 & \begin{tabular}{|l|l}
0.415 \\
\end{tabular} & 0.180 & 0.210 & 0.128 & -0.332 & -0.091 & -0.287 \\
\hline (3) $\mathrm{CO}_{3}^{2}$ & 176 & 0.042 & 1.000 & 0.084 & 0.175 & 0.211 & 0.024 & $|-0.014|$ & \begin{tabular}{|l|}
-0.352 \\
\end{tabular} & 0.221 & 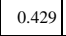 & 0.224 & \begin{tabular}{|l|} 
\\
\end{tabular} & $|-0.146|$ & -0.061 & \begin{tabular}{|l|l|} 
& 0.501 \\
\end{tabular} & 0.033 & 0.066 & $|-0.019|$ & 0.829 & 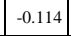 & 0.042 & 0.164 & \begin{tabular}{|l|} 
\\
\end{tabular} & 0.699 & 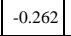 & \begin{tabular}{|l|}
0.106 \\
\end{tabular} & $|-0.282|$ & 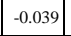 & 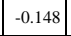 & 0.084 & 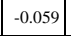 & -0.208 & -0.262 & 0.28 \\
\hline $\mathrm{NO}_{2}$ & & 0.163 & 0.084 & 1.000 & -0.116 & 0.300 & $|-0.002|$ & 0.337 & \begin{tabular}{|l|}
-0.014 \\
\end{tabular} & 0.137 & $|-0.154|$ & 0.051 & 0.388 & $|0.157|$ & 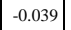 & $|-0.187|$ & 0.431 & 0.300 & \begin{tabular}{|l|}
0.131 \\
\end{tabular} & \begin{tabular}{|l|}
$\mid-0.084$ \\
\end{tabular} & \begin{tabular}{|l|} 
\\
\end{tabular} & -0.351 & 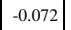 & $|-0.030|$ & 0.009 & $\mid 0.326$ & $|-0.040|$ & -0.243 & 0.021 & 0.073 & 0.310 & $\mid 0.311$ & -0.076 & 0.272 & 0.083 \\
\hline (5) $\mathrm{NO}_{3}$ & 0.305 & -0.038 & \begin{tabular}{|l|l|} 
& 0.175 \\
\end{tabular} & -0.116 & 1.000 & \begin{tabular}{|l|}
0.281 \\
\end{tabular} & 0.076 & \begin{tabular}{|l|} 
\\
\end{tabular} & \begin{tabular}{|l|}
-0.306 \\
\end{tabular} & 0.155 & \begin{tabular}{|l|}
0.162 \\
\end{tabular} & 0.105 & $|-0.133|$ & $\mid 0.232$ & 0.479 & \begin{tabular}{|l|} 
\\
\end{tabular} & 0.368 & 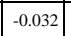 & \begin{tabular}{|l|}
0.006 \\
\end{tabular} & 0.120 & 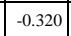 & 0.815 & 0.239 & $|-0.191|$ & -0.003 & $|-0.179|$ & \begin{tabular}{|l|l|} 
& 0.391 \\
\end{tabular} & 0.134 & \begin{tabular}{|l|l|}
0.067 \\
\end{tabular} & -0.063 & -0.168 & \begin{tabular}{|l|}
$\mid-0.117$ \\
\end{tabular} & 0.274 & \begin{tabular}{|l|} 
\\
\end{tabular} & 0.138 \\
\hline 6) $\mathrm{OH}$ & 0.921 & 0.667 & 0.211 & 0.300 & 0.281 & 1.000 & $\mid$\begin{tabular}{|c|}
$\mid-0.118$ \\
\end{tabular} & $0.057 \mid$ & 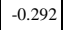 & 0.356 & \begin{tabular}{|l|}
0.252 \\
\end{tabular} & 0.204 & $|-0.027|$ & \begin{tabular}{|l|} 
\\
\end{tabular} & 0.283 & $|-0.075|$ & 0.142 & 0.079 & \begin{tabular}{|l|}
0.731 \\
\end{tabular} & 0.098 & 0.174 & 0.115 & 0.339 & $\mid$\begin{tabular}{|c|}
$\mid$ \\
\end{tabular} & 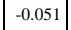 & -0.024 & \begin{tabular}{|l|}
0.016 \\
\end{tabular} & \begin{tabular}{|l|} 
\\
\end{tabular} & \begin{tabular}{|l|} 
\\
\end{tabular} & 0.112 & 0.110 & \begin{tabular}{|l|} 
\\
\end{tabular} & -0.019 & -0.006 & -0.035 \\
\hline 7) $\mathrm{SO}$ & .115 & -0.418 & 0.024 & -0.002 & 0.076 & -0.118 & 1.000 & -0.203 & 0.067 & 0.234 & 0.233 & -0.254 & 0.067 & -0.196 & -0.243 & 0.132 & -0.083 & 0.013 & -0.374 & -0.049 & -0.002 & 0.082 & 0.193 & 0.187 & 0.378 & 0.338 & 0.574 & 0.693 & 0.049 & -0.382 & 0.051 & 0.012 & -0.078 & 0.288 & -0.014 \\
\hline 8) Temp. & 1.143 & -0.045 & -0.014 & 0.337 & 0.057 & 0.057 & $|-0.203|$ & 1.000 & $|-0.071|$ & -0.033 & -0.116 & $|-0.150|$ & -0.028 & $\mid 0.117$ & -0.082 & $|-0.108|$ & 0.277 & 0.244 & $\mid 0.018$ & -0.040 & 0.359 & $\mid-0.035$ & -0.216 & $|-0.080|$ & 0.046 & 0.197 & $|-0.051|$ & -0.382 & $|-0.207|$ & 0.146 & 0.218 & 0.534 & 0.329 & 0.798 & 0.49. \\
\hline (9) $\mathrm{Al}(\mathrm{Ol}$ & 4.499 & -0.483 & 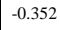 & -0.014 & -0.306 & 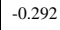 & 0.067 & -0.071 & 1.000 & -0.781 & -0.527 & $|-0.537|$ & \begin{tabular}{|l|} 
\\
\end{tabular} & \begin{tabular}{|l|} 
\\
\end{tabular} & 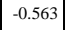 & \begin{tabular}{|l|} 
\\
\end{tabular} & -0.150 & 0.059 & \begin{tabular}{|l|}
-0.424 \\
\end{tabular} & $|-0.040|$ & 0.247 & -0.024 & -0.010 & $|-0.370|$ & \begin{tabular}{|c|}
$\mid-0.046$ \\
\end{tabular} & 0.422 & \begin{tabular}{|l|}
$\mid-0.242$ \\
\end{tabular} & 0.134 & \begin{tabular}{|l|} 
\\
\end{tabular} & 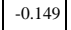 & 0.048 & $|-0.233|$ & 0.358 & 0.191 & -0.032 \\
\hline (10) $\mathrm{CO}_{3}^{2+2}$ & 0.532 & 0.705 & 0.221 & 0.137 & 0.155 & \begin{tabular}{|l|l|} 
& 0.356
\end{tabular} & 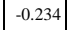 & $|-0.033|$ & $|-0.781|$ & 1.000 & 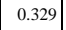 & \begin{tabular}{|l|} 
\\
\end{tabular} & \begin{tabular}{|l|} 
\\
\end{tabular} & $|-0.279|$ & 0.650 & $-0.521 \mid$ & 0.098 & -0.045 & 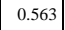 & $|-0.126|$ & -0.190 & -0.109 & -0.019 & \begin{tabular}{|l|} 
\\
\end{tabular} & 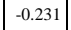 & \begin{tabular}{|l|} 
\\
\end{tabular} & $|-0.006|$ & -0.099 & \begin{tabular}{|l|} 
\\
\end{tabular} & 0.143 & 0.087 & \begin{tabular}{|l|} 
\\
\end{tabular} & -0.352 & -0.191 & -0.232 \\
\hline (11) $\mathrm{CO}_{3}^{2 *} * \mathrm{CO}_{3}^{2}$ & 0.320 & 0.330 & 0.429 & -0.154 & 0.162 & \begin{tabular}{|l|l}
0.252 \\
\end{tabular} & 0.233 & $|-0.116|$ & $|-0.527|$ & 0.329 & 1.000 & 0.310 & 0.086 & $|-0.279|$ & 0.138 & $|0.120|$ & -0.066 & $\mid-0.172$ & $\mid 0.323$ & 0.158 & -0.381 & $\mid 0.028$ & 0.074 & $\mid 0.276$ & 0.371 & \begin{tabular}{|l|} 
\\
\end{tabular} & 0.357 & 0.060 & 0.271 & -0.245 & -0.024 & $\mid 0.093$ & -0.296 & -0.340 & 0.03 \\
\hline (12) $\mathrm{NO}_{2}^{-*} \mathrm{Al}(\mathrm{OH})_{4}^{-}$ & 0.347 & 0.554 & 0.224 & 0.051 & 0.105 & 0.204 & -0.254 & $-0.150 \mid$ & $|-0.537|$ & 0.732 & \begin{tabular}{|l|l|}
0.310 \\
\end{tabular} & 1.000 & 0.017 & $|-0.122|$ & 0.527 & $|-0.269|$ & -0.108 & $|-0.256|$ & 0.329 & $|-0.037|$ & -0.279 & $|-0.056|$ & 0.015 & $\mid 0.279$ & -0.148 & $|-0.772|$ & -0.129 & 0.066 & 0.391 & -0.011 & 0.013 & $\mid-0.052$ & -0.156 & 0.169 & -0.13 \\
\hline (13) $\mathrm{NO}_{2}^{2} * \mathrm{CO}_{3}^{2}$ & 0.138 & 0.065 & 0.410 & 0.388 & -0.133 & \begin{tabular}{|l|l|}
-0.027 \\
\end{tabular} & 0.067 & $-0.028 \mid$ & 0.059 & 0.078 & 0.086 & 0.017 & 1.000 & \begin{tabular}{|l|l|}
-0.320 \\
\end{tabular} & -0.130 & 0.230 & 0.038 & 0.061 & -0.002 & 0.058 & 0.212 & -0.198 & -0.067 & 0.064 & 0.378 & -0.054 & $|0.052|$ & -0.115 & 0.013 & -0.089 & 0.527 & -0.093 & -0.364 & -0.115 & -0.162 \\
\hline (14) $\mathrm{NO}_{2} * \mathrm{NO}_{3}$ & .050 & -0.194 & -0.146 & 0.157 & 0.232 & 0.052 & -0.196 & 0.117 & 0.198 & -0.279 & $|-0.279|$ & $|-0.122|$ & $|-0.320|$ & $\mid$\begin{tabular}{|c|}
$\mid 1.000$ \\
\end{tabular} & 0.013 & 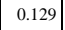 & 0.412 & $|-0.055|$ & $|-0.134|$ & \begin{tabular}{|l|l|} 
& 0.098 \\
\end{tabular} & 0.125 & 0.125 & -0.165 & $|-0.326|$ & $|-0.199|$ & \begin{tabular}{|l|} 
\\
\end{tabular} & $|-0.196|$ & -0.003 & $|-0.313|$ & 0.105 & -0.239 & $|-0.299|$ & 0.544 & 0.360 & 0.337 \\
\hline 15) N & & 0.491 & -0.061 & -0.039 & 0.479 & 0.283 & -0.243 & -0.082 & $-0.563]$ & 0.650 & 0.138 & 0.527 & -0.130 & $\mid 0.013$ & 1.000 & -0.356 & 0.042 & -0.383 & 0.438 & -0.253 & -0.274 & 0.12. & 0.007 & -0.022 & -0.425 & -0.430 & -0.07 .5 & 0.040 & 0.475 & 0.226 & $-0.012 \quad>\quad>$ & 0.03. & -0.134 & $-0.04-4>$ & -0.25 \\
\hline & & 394 & 0.501 & -0.187 & 202 & -0.075 & 32 & -0.108 - & 0.296 & -0.521 & 0.120 & -0.269 & 0.230 & 0.129 & -0.356 & & -0.134 & -0.156 & -0.332 & 0.579 & -0.149 & 0.293 & 0.126 & -0.065 & 0.602 & 0.041 & 0.08 & -0.066 & -0.460 & -0.185 & 0.013 & -0.36 & 0.063 & $0.08<>>8$ & 0.24. \\
\hline (17) $\mathrm{NO}_{3} * \mathrm{NO}_{2}^{2}$ & 0.224 & 0.003 & 0.033 & 0.431 & 0.368 & 0.142 & $|-0.083|$ & 0.277 & $|-0.150|$ & 0.098 & -0.066 & \begin{tabular}{|c|}
-0.108 \\
\end{tabular} & 0.038 & $\mid 0.412$ & 0.042 & $|-0.134|$ & 1.000 & 0.303 & \begin{tabular}{|c|}
0.045 \\
\end{tabular} & 0.000 & 0.251 & $0.090 \mid$ & -0.233 & $|-0.176|$ & -0.082 & \begin{tabular}{|l|}
0.093 \\
\end{tabular} & 0.175 & -0.143 & 0.049 & 0.118 & -0.055 & 0.141 & 0.164 & $0.24 \mathrm{t}$ & 0.19 \\
\hline (18) $\mathrm{NO}_{3}{ }^{*} \mathrm{NO}_{3}$ & 0.068 & -0.092 & 0.066 & $0.300 \mid$ & -0.032 & 0.079 & 0.013 & 0.244 & \begin{tabular}{|c|}
0.059 \\
\end{tabular} & -0.045 & -0.172 & $-0.256 \mid$ & 0.061 & $|-0.055|$ & -0.383 & $|-0.156|$ & 0.303 & 1.000 & $|-0.090|$ & 0.149 & 0.381 & 0.071 & 0.048 & 0.104 & 0.108 & 0.347 & 0.016 & -0.251 & -0.194 & 0.047 & 0.085 & 0.273 & -0.019 & 0.117 & 0.166 \\
\hline (19) $\mathrm{OH}^{*} \mathrm{Al}(\mathrm{OH})$ & 0.749 & 0.955 & -0.019 & 0.131 & 0.006 & 0.731 & -0.374 & \begin{tabular}{|l|l|}
0.018 \\
\end{tabular} & -0.424 & 0.563 & 0.323 & 0.329 & \begin{tabular}{|l|}
-0.002 \\
\end{tabular} & \begin{tabular}{|c|}
$\mid-0.134$ \\
\end{tabular} & 0.438 & \begin{tabular}{|l|}
-0.332 \\
\end{tabular} & 0.045 & $-0.090 \mid$ & $\mid 1.000$ & $|-0.270|$ & -0.051 & \begin{tabular}{|l|}
-0.219 \\
\end{tabular} & -0.075 & $|-0.110|$ & $|-0.204|$ & $|-0.144|$ & $\mid-0.054$ & $\mid-0.308$ & $\mid 0.330$ & 0.195 & 0.187 & 0.147 & -0.269 & -0.026 & -0.23 \\
\hline (20) $\mathrm{OH}^{*} \mathrm{CO}_{3}^{2}$ & 0.114 & -0.253 & 0.829 & -0.084 & 0.120 & 0.098 & -0.049 & $|-0.040|$ & $|-0.040|$ & -0.126 & \begin{tabular}{|c|}
0.158 \\
\end{tabular} & $|-0.037|$ & 0.058 & \begin{tabular}{|c|}
$\mid 0.098$ \\
\end{tabular} & -0.253 & 0.579 & 0.000 & 0.149 & \begin{tabular}{|l|}
-0.270 \\
\end{tabular} & \begin{tabular}{|l|}
1.000 \\
\end{tabular} & $|-0.081|$ & 0.139 & 0.238 & 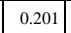 & 0.547 & $|-0.091|$ & 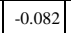 & $|-0.269|$ & 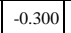 & $|-0.093|$ & -0.166 & -0.139 & 0.062 & -0.192 & 0.37 \\
\hline (21) $\mathrm{OH}^{*} \mathrm{NO}_{2}^{-}$ & 0.151 & -0.080 & $\mid-0.114$ & 0.849 & -0.320 & 0.174 & \begin{tabular}{|l|}
-0.002 \\
\end{tabular} & 0.359 & \begin{tabular}{|c|}
0.247 \\
\end{tabular} & -0.190 & $|-0.381|$ & $|-0.279|$ & 0.212 & $\mid$\begin{tabular}{|c|}
$\mid$ \\
$\mid$
\end{tabular} & $\mid$\begin{tabular}{|l|}
$\mid-0.274$ \\
\end{tabular} & $|-0.149|$ & 0.251 & 0.381 & $|-0.051|$ & $|-0.081|$ & 1.000 & -0.380 & -0.006 & $|-0.038|$ & \begin{tabular}{|c|}
-0.029 \\
\end{tabular} & \begin{tabular}{|l|}
0.530 \\
\end{tabular} & $|-0.161|$ & $|-0.248|$ & $|-0.215|$ & 0.112 & 0.208 & $\mid 0.358$ & 0.009 & 0.333 & 0.096 \\
\hline (22) 01 & & -0.255 & 0.042 & -0.351 & 0.815 & 0.115 & 0.082 & -0.035 & -0.024 & -0.109 & 0.028 & $-0.056 \mid$ & $-0.198 \mid$ & $\mid 0.125$ & 0.125 & 0.293 & 0.090 & 0.071 & $|-0.219|$ & 0.139 & -0.380 & 1.000 & 0.429 & $-0.206 \mid$ & \begin{tabular}{|c|}
-0.030 \\
\end{tabular} & $|-0.112|$ & \begin{tabular}{|l|l|} 
& 0.276 \\
\end{tabular} & 0.204 & $|-0.110|$ & -0.097 & -0.237 & $|-0.216|$ & 0.348 & 0.010 & 0.104 \\
\hline (23) $\mathrm{OH}^{*} \mathrm{*H}$ & 0.148 & -0.066 & 0.164 & -0.072 & 0.239 & 0.339 & 0.193 & -0.216 & -0.010 & -0.019 & 0.074 & 0.015 & -0.067 & -0.165 & 0.007 & 0.126 & -0.233 & 0.048 & -0.075 & 0.238 & 0.006 & 0.429 & 1.000 & 0.039 & 0.044 & -0.032 & 0.058 & 0.225 & -0.017 & -0.031 & -0.022 & -0.016 & 0.008 & 0.30 & 0.01 \\
\hline (24) $\mathrm{SO}_{4}^{2 * *} \mathrm{Al}(\mathrm{OH}$ & -0.041 & 0.007 & 0.329 & -0.030 & -0.191 & -0.188 & 0.187 & -0.080 & -0.370 & 0.240 & 0.276 & 0.279 & 0.064 & -0.326 & -0.022 & -0.069 & -0.176 & 0.104 & $\mid-0.110$ & 0.201 & -0.038 & -0.206 & 0.039 & 1.000 & 0.337 & -0.261 & -0.049 & -0.086 & 0.040 & -0.326 & -0.019 & 0.22 .5 & -0.242 & $0.228>>$ & 0.071 \\
\hline (25) $\mathrm{SO}_{4}^{2} * \mathrm{CO}_{3}^{2}$ & 0.088 & -0.228 & 0.699 & 0.009 & -0.003 & -0.051 & 0.378 & 0.046 & -0.046 & -0.231 & 0.371 & -0.148 & 0.378 & \begin{tabular}{|l|l|} 
& -0.199 \\
\end{tabular} & -0.425 & 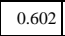 & -0.082 & 0.108 & $|-0.204|$ & 0.547 & $|-0.029|$ & $|-0.030|$ & 0.044 & 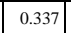 & 1.000 & 0.059 & $|0.310|$ & $\mid-0.116$ & $|-0.267|$ & -0.368 & 0.124 & -0.035 & -0.133 & 0.17 & 0.29: \\
\hline (26) $\mathrm{SO}_{4}{ }^{2} * \mathrm{NO}_{2}{ }^{-}$ & -0.107 & -0.327 & -0.262 & 0.326 & -0.179 & $\mid-0.024$ & 0.338 & \begin{tabular}{|l|l|} 
& 0.197 \\
\end{tabular} & 0.422 & -0.513 & \begin{tabular}{|c|c|}
-0.305 \\
\end{tabular} & \begin{tabular}{|c|}
$\mid-0.772$ \\
\end{tabular} & \begin{tabular}{|c|c|}
-0.054 \\
\end{tabular} & \begin{tabular}{|l|l|}
0.035 \\
\end{tabular} & -0.430 & 0.041 & 0.093 & 0.347 & \begin{tabular}{|l|l|}
-0.144 \\
\end{tabular} & \begin{tabular}{|c|c|}
-0.091 \\
\end{tabular} & 0.530 & -0.112 & -0.032 & -0.261 & 0.059 & 1.000 & 0.168 & \begin{tabular}{|c|}
$\mid-0.118$ \\
\end{tabular} & \begin{tabular}{|c|}
-0.224 \\
\end{tabular} & 0.040 & 0.063 & 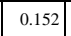 & 0.069 & 0.197 & 0.112 \\
\hline (27) $\mathrm{SO}_{4}^{2-*} \mathrm{NO}_{3}^{-}$ & 0.103 & -0.125 & 0.106 & -0.040 & 0.391 & 0.016 & 0.574 & $-0.051 \mid$ & \begin{tabular}{|c|}
-0.242 \\
\end{tabular} & -0.006 & 0.357 & $|-0.129|$ & \begin{tabular}{|l|}
0.052 \\
\end{tabular} & $|-0.196|$ & -0.075 & 0.085 & 0.175 & 0.016 & $\mid-0.054$ & \begin{tabular}{|c|}
$\mid-0.082$ \\
\end{tabular} & -0.161 & 0.276 & 0.058 & $|-0.049|$ & \begin{tabular}{|l|}
0.310 \\
\end{tabular} & \begin{tabular}{|l|}
0.168 \\
\end{tabular} & \begin{tabular}{|l|}
1.000 \\
\end{tabular} & 0.292 & $\mid 0.289$ & $|-0.213|$ & \begin{tabular}{|l|}
-0.016 \\
\end{tabular} & 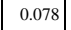 & -0.201 & -0.216 & 0.034 \\
\hline (28) $\mathrm{SO}_{4}^{2 *} \mathrm{OH}$ & -0.178 & -0.279 & -0.282 & -0.243 & 0.134 & \begin{tabular}{|l|l|}
-0.079 \\
\end{tabular} & 0.693 & $|-0.382|$ & $\mid$\begin{tabular}{|l|l|} 
& 0.134 \\
\end{tabular} & -0.099 & 0.060 & 0.066 & -0.115 & $|-0.003|$ & 0.040 & $|-0.066|$ & -0.143 & -0.251 & -0.308 & -0.269 & -0.248 & 0.204 & 0.225 & $|-0.086|$ & $|-0.116|$ & $|-0.118|$ & $\mid 0.292$ & 1.000 & 0.076 & -0.198 & -0.092 & $\mid-0.212$ & 0.098 & $-0.22>0$ & -0.23 \\
\hline (29) $\mathrm{SO}_{4}{ }^{2 *} \mathrm{SO}_{4}{ }^{2-}$ & 0.141 & 0.415 & -0.039 & 0.021 & 0.067 & 0.048 & 0.049 & -0.207 & -0.584 & 0.644 & 0.271 & 0.391 & 0.013 & -0.313 & 0.475 & $-0.460 \mid$ & 0.049 & -0.194 & 0.330 & -0.300 & -0.215 & -0.110 & -0.017 & 0.040 & -0.267 & -0.224 & 0.289 & 0.076 & 1.000 & 0.134 & 0.025 & 0.165 & -0.493 & -0.343 & $-0.402->>$ \\
\hline (30) Temp.* $\mathrm{Al}(\mathrm{OH})$ & 0.095 & 0.180 & -0.148 & 0.073 & -0.063 & 0.112 & -0.382 & 0.146 & \begin{tabular}{|l|}
-0.149 \\
\end{tabular} & 0.143 & -0.245 & \begin{tabular}{|l|l|}
-0.011 \\
\end{tabular} & -0.089 & 0.105 & 0.226 & \begin{tabular}{|c|}
-0.185 \\
\end{tabular} & 0.118 & 0.047 & 0.195 & -0.093 & 0.112 & -0.097 & -0.031 & \begin{tabular}{|c|}
-0.326 \\
\end{tabular} & -0.368 & 0.040 & \begin{tabular}{|l|}
-0.213 \\
\end{tabular} & \begin{tabular}{|l|}
-0.198 \\
\end{tabular} & \begin{tabular}{|l|l|}
0.134 \\
\end{tabular} & 1.000 & -0.045 & \begin{tabular}{|l|l|}
-0.010 \\
\end{tabular} & -0.251 & 0.099 & -0.232 \\
\hline (31) Temp. ${ }^{*} \mathrm{CO}_{3}{ }^{2}$ & 0.189 & 0.210 & \begin{tabular}{|l|l|} 
& 0.084 \\
\end{tabular} & 0.310 & -0.168 & 0.110 & 0.051 & 0.218 & \begin{tabular}{|c|}
0.048 \\
\end{tabular} & 0.087 & $|-0.024|$ & 0.013 & 0.527 & $|-0.239|$ & -0.012 & {$[-0.013 \mid$} & -0.055 & 0.085 & \begin{tabular}{|l|l|}
0.187 \\
\end{tabular} & -0.166 & 0.208 & -0.237 & -0.022 & $|-0.019|$ & 0.124 & \begin{tabular}{|l|} 
\\
\end{tabular} & $|-0.016|$ & $\mid-0.092$ & \begin{tabular}{|c|}
0.025 \\
\end{tabular} & -0.045 & 1.000 & $|0.107|$ & -0.262 & 0.155 & -0.148 \\
\hline & 0.162 & 0.128 & -0.059 & 0.311 & -0.117 & 0.110 & 0.012 & 0.534 & -0.233 & 0.192 & 0.093 & -0.052 & -0.093 & -0.299 & 0.034 & -0.364 & 0.141 & 0.273 & 0.147 & -0.139 & 0.358 & -0.216 & -0.010 & 0.225 & -0.035 & 0.152 & 0.078 & -0.212 & 0.165 & -0.010 & 0.107 & 1.000 & 0.140 & 0.206 & 0.075 \\
\hline & -0.13 & -0.332 & -0.208 & -0.076 & 0.2 & -0.0 & -0.078 & 0. & 0.358 & -0.352 & -0.2 & -0.156 & -0.364 & 0. & -0.134 & & 0.164 & -0.019 & -0. & 0.062 & 0.009 & & -0.008 & -0.242 & -0.133 & 0.068 & -0.201 & . 098 & -0.493 & -0.251 & 0.262 & 0.140 & . 000 & . 50 & 0.4033 \\
\hline Temp. ${ }^{*} \mathrm{OH}$ & 0.006 & -0.091 & -0.262 & 0.272 & 0.056 & -0.006 & -0.288 & 0.798 & 0.191 & -0.191 & -0.340 & $|-0.169|$ & -0.115 & 0.360 & -0.049 & -0.089 & 0.240 & 0.117 & -0.026 & -0.192 & 0.333 & 0.010 & -0.305 & $|-0.228|$ & 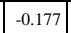 & 0.197 & $|-0.216|$ & -0.290 & -0.343 & 0.099 & 0.155 & 0.206 & 0.505 & 1.000 & 0.389 \\
\hline ) $\mathrm{Temp}^{*} \mathrm{SO}_{4}{ }^{2}$ & 0.005 & -0.287 & 0.280 & 0.083 & 0.138 & -0.035 & -0.014 & 0.495 & -0.032 & -0.232 & 0.035 & -0.133 & -0.162 & 0.337 & -0.258 & 0.24 & 0.195 & 0.166 & -0.230 & 0.379 & 0.096 & 0.104 & -0.010 & 0.071 & 0.295 & 0.112 & 0.034 & -0.236 & $|-0.402|$ & -0.232 & -0.148 & 0.075 & 0.403 & 0.389 & 1.000 \\
\hline
\end{tabular}




\section{Appendix B Preparation of Salt Solutions}

The target mass of each starting material for the preparation of the salt solution is shown in Table B.1.

Table B.1 Target Mass of Starting Materials

\begin{tabular}{|c|c|c|c|c|c|c|c|}
\hline Solution & $\begin{array}{c}\mathrm{NaOH} \\
50 \mathrm{wt} \% \\
(\mathrm{~g}) \\
\end{array}$ & $\begin{array}{c}\mathrm{Al}\left(\mathrm{NO}_{3}\right)_{3} \\
\cdot 9 \mathrm{H}_{2} \mathrm{O} \\
(\mathrm{g}) \\
\end{array}$ & $\begin{array}{c}\mathrm{Na}_{2} \mathrm{SO}_{4} \\
\cdot 10 \mathrm{H}_{2} \mathrm{O} \\
(\mathrm{g}) \\
\end{array}$ & $\begin{array}{c}\mathrm{Na}_{2} \mathrm{CO}_{3} \\
\cdot \mathrm{H}_{2} \mathrm{O} \\
(\mathrm{g}) \\
\end{array}$ & $\begin{array}{r}\mathrm{NaNO}_{3} \\
(\mathrm{~g}) \\
\end{array}$ & $\begin{array}{c}\mathrm{NaNO}_{2} \\
(\mathrm{~g}) \\
\end{array}$ & Notes \\
\hline 1 & 120.023 & 0.038 & 0.032 & 0.012 & 0.824 & 0.690 & \\
\hline $1 \mathrm{~A}$ & 120.023 & 0.038 & 0 & 0.012 & 0.824 & 0.690 & 1 \\
\hline 2 & 120.023 & 0.038 & 0.032 & 0.012 & 0.824 & 0.690 & \\
\hline $2 \mathrm{~A}$ & 120.023 & 0.038 & 0 & 0.012 & 0.824 & 0.690 & 1 \\
\hline 3 & 44.624 & 0.626 & 0.509 & 11.296 & 5.968 & 5.624 & \\
\hline $3 \mathrm{~A}$ & 44.624 & 0.626 & 0.509 & 7.440 & 5.968 & 5.624 & 2 \\
\hline 4 & 11.210 & 4.963 & 0.335 & 11.008 & 38.100 & 8.737 & \\
\hline 5 & 11.210 & 4.963 & 0.335 & 11.008 & 38.100 & 8.737 & \\
\hline 6 & 39.356 & 24.875 & 6.653 & 0.733 & 4.100 & 20.621 & \\
\hline 7 & 17.858 & 4.250 & 3.895 & 4.498 & 2.432 & 37.453 & \\
\hline 8 & 26.331 & 15.493 & 11.145 & 2.962 & 2.953 & 28.301 & \\
\hline 9 & 46.552 & 22.842 & 6.950 & 5.630 & 6.246 & 6.041 & \\
\hline $9 \mathrm{~A}$ & 46.552 & 22.842 & 6.950 & 3.100 & 6.246 & 6.041 & 3 \\
\hline 10 & 47.355 & 28.364 & 15.549 & 2.749 & 6.124 & 4.335 & \\
\hline $10 \mathrm{~A}$ & 47.355 & 28.364 & 8.055 & 2.749 & 6.124 & 4.335 & 4 \\
\hline 11 & 50.304 & 4.232 & 13.181 & 3.613 & 0.139 & 6.683 & \\
\hline $11 \mathrm{~A}$ & 50.304 & 4.232 & 8.055 & 3.613 & 0.139 & 6.683 & 5 \\
\hline 12 & 23.588 & 1.808 & 2.835 & 11.584 & 0.204 & 24.830 & \\
\hline 13 & 29.004 & 22.553 & 3.583 & 0.444 & 19.924 & 12.523 & \\
\hline 14 & 4.630 & 1.174 & 3.460 & 0.900 & 30.179 & 23.568 & \\
\hline 15 & 34.023 & 27.782 & 5.828 & 11.777 & 2.375 & 1.163 & \\
\hline 16 & 34.023 & 27.782 & 5.828 & 11.777 & 2.375 & 1.163 & \\
\hline 17 & 18.157 & 1.876 & 15.049 & 10.240 & 0.850 & 5.480 & \\
\hline 18 & 9.035 & 2.521 & 5.828 & 11.777 & 2.250 & 0.762 & \\
\hline 19 & 5.238 & 0.251 & 14.054 & 5.534 & 4.207 & 2.880 & \\
\hline 20 & 21.810 & 0.923 & 2.713 & 0.156 & 0.727 & 1.003 & \\
\hline
\end{tabular}

(1) $\mathrm{SO}_{4}{ }^{2-}$ was reduced from $0.001 \mathrm{M}$ to $0 \mathrm{M}$

(2) $\mathrm{CO}_{3}^{2-}$ was reduced from $0.9109 \mathrm{M}$ to $0.60 \mathrm{M}$

(3) $\mathrm{CO}_{3}{ }^{2-}$ was reduced from $0.4540 \mathrm{M}$ to $0.25 \mathrm{M}$

(4) $\mathrm{SO}_{4}{ }^{2-}$ was reduced from $0.4826 \mathrm{M}$ to $0.25 \mathrm{M}$

(5) $\mathrm{SO}_{4}{ }^{2-}$ was reduced from $0.4091 \mathrm{M}$ to $0.25 \mathrm{M}$

The actual mass of each starting material used to prepare the salt solutions is shown in Table B.2. 
Table B.2 Actual Mass of Starting Materials

\begin{tabular}{cccccccc}
\hline \hline Solution & $\begin{array}{c}\mathrm{NaOH} \\
50 \mathrm{wt} \% \\
(\mathrm{~g})\end{array}$ & $\begin{array}{c}\mathrm{Al}\left(\mathrm{NO}_{3}\right)_{3} \\
(\mathrm{~g})\end{array}$ & $\begin{array}{c}\mathrm{Na}_{2} \mathrm{SO}_{4} \\
\cdot 10 \mathrm{H}_{2} \mathrm{O} \\
(\mathrm{g})\end{array}$ & $\begin{array}{c}\mathrm{Na}_{2} \mathrm{CO}_{3} \\
\bullet \mathrm{H}_{2} \mathrm{O} \\
(\mathrm{g})\end{array}$ & $\begin{array}{c}\mathrm{NaNO}_{3} \\
(\mathrm{~g})\end{array}$ & $\begin{array}{c}\mathrm{NaNO}_{2} \\
(\mathrm{~g})\end{array}$ & Notes \\
\hline $1 \mathrm{~A}$ & 120.0200 & 0.0389 & 0 & 0.0118 & 0.8247 & 0.6900 & \\
$2 \mathrm{~A}$ & 120.0200 & 0.0393 & 0 & 0.0122 & 0.8242 & 0.6902 & \\
$3 \mathrm{~A}$ & 44.6297 & 0.6264 & 0.5112 & 7.4419 & 5.9688 & 5.6262 & \\
4 & 11.2167 & 4.9631 & 0.3385 & 11.0091 & 38.1005 & 8.7380 & \\
5 & 11.2116 & 4.9632 & 0.3366 & 11.0081 & 38.1001 & 8.7370 & \\
6 & 39.3582 & 24.8751 & 6.6552 & 0.7334 & 4.1005 & 20.6211 & \\
7 & 17.8643 & 4.2510 & 3.8953 & 4.5008 & 2.4328 & 37.4536 & \\
8 & 26.3388 & 15.4930 & 11.1485 & 2.9622 & 2.9534 & 28.3016 & 1 \\
$9 \mathrm{~A}$ & 46.5500 & 22.8423 & 6.9500 & 3.1009 & 6.2468 & 6.0419 & 2 \\
$10 \mathrm{~A}$ & 47.3553 & 28.3642 & 8.0552 & 2.7494 & 6.1251 & 4.3358 & \\
$11 \mathrm{~A}$ & 50.3000 & 4.2324 & 8.0556 & 3.6141 & 0.1398 & 6.6838 & 3 \\
12 & 23.5943 & 1.8086 & 2.8352 & 11.5847 & 0.2044 & 24.8309 & 4 \\
13 & 29.0065 & 22.5527 & 3.5850 & 0.4442 & 19.9242 & 12.5239 & \\
14 & 4.6312 & 1.1742 & 3.4643 & 0.9007 & 30.1795 & 23.5685 & \\
15 & 34.0226 & 27.7822 & 5.8287 & 11.7775 & 2.3764 & 1.1639 & \\
16 & 34.0248 & 27.7829 & 5.8290 & 11.7779 & 2.3759 & 1.1638 & \\
17 & 18.1584 & 1.8784 & 15.0494 & 10.2415 & 0.8509 & 5.4810 & \\
18 & 9.0392 & 2.5214 & 5.8302 & 11.7777 & 2.2511 & 0.7629 & \\
19 & 5.2395 & 0.2519 & 14.0541 & 5.5344 & 4.2072 & 2.8812 & \\
20 & 21.8108 & 0.9234 & 2.7154 & 0.1561 & 0.7287 & 1.0039 & \\
\hline
\end{tabular}

(1) Final volume was $111.0 \mathrm{~mL}$

(2) Final volume was $101.0 \mathrm{~mL}$

(3) Final volume was $103.5 \mathrm{~mL}$

(4) Final volume was $105.5 \mathrm{~mL}$ 


\section{Appendix C Pu and Am Solubilities in Simulated Salt Solutions}

The $\mathrm{Pu}$ and Am solubilities measured in the salt solutions as a function of the equilibration time are given in Table C.1 - C.3. The Pu and Am concentrations measured in the blank and standard solutions are also included for each data set. For convenience, the solubilities are given in both $\mu \mathrm{g} / \mathrm{mL}$ and moles/L.

Table C.1 Pu and Am Solubility in Salt Solutions - Sample 1

\begin{tabular}{cccccc}
\hline \hline Solution & $\begin{array}{c}\text { Equilibration } \\
\text { Time } \\
(\text { days })\end{array}$ & $\begin{array}{c}\text { Pu } \\
\text { Solubility } \\
(\mu \mathrm{g} / \mathrm{mL})\end{array}$ & $\begin{array}{c}\text { Pu } \\
\text { Solubility } \\
(\mathrm{moles} / \mathrm{L})\end{array}$ & $\begin{array}{c}\text { Am } \\
\text { Solubility } \\
(\mu \mathrm{g} / \mathrm{mL})\end{array}$ & $\begin{array}{c}\text { Am } \\
\text { Solubility } \\
(\mathrm{moles} / \mathrm{L})\end{array}$ \\
\hline $1 \mathrm{~A}$ & 40 & 3.5 & $1.5 \mathrm{E}-05$ & 1.7 & $7.2 \mathrm{E}-06$ \\
$2 \mathrm{~A}$ & 41 & 4.8 & $2.0 \mathrm{E}-05$ & 1.5 & $6.2 \mathrm{E}-06$ \\
$3 \mathrm{~A}$ & 41 & 3.3 & $1.4 \mathrm{E}-05$ & 0.19 & $7.7 \mathrm{E}-07$ \\
4 & 40 & 1.3 & $5.4 \mathrm{E}-06$ & 0.19 & $7.8 \mathrm{E}-07$ \\
5 & 41 & 1.0 & $4.3 \mathrm{E}-06$ & 0.27 & $1.1 \mathrm{E}-06$ \\
6 & 41 & 0.66 & $2.8 \mathrm{E}-06$ & 0.27 & $1.1 \mathrm{E}-06$ \\
7 & 41 & 0.63 & $2.6 \mathrm{E}-06$ & 0.34 & $1.4 \mathrm{E}-06$ \\
8 & 40 & 0.86 & $3.6 \mathrm{E}-06$ & 0.19 & $7.8 \mathrm{E}-07$ \\
$9 \mathrm{~A}$ & 40 & 1.6 & $6.6 \mathrm{E}-06$ & 0.21 & $8.8 \mathrm{E}-07$ \\
$10 \mathrm{~A}$ & 41 & 0.68 & $2.8 \mathrm{E}-06$ & 0.36 & $1.5 \mathrm{E}-06$ \\
$11 \mathrm{~A}$ & 41 & 2.6 & $1.1 \mathrm{E}-05$ & 0.05 & $2.1 \mathrm{E}-07$ \\
12 & 40 & 2.4 & $1.0 \mathrm{E}-05$ & 0.78 & $3.2 \mathrm{E}-06$ \\
13 & 40 & 0.68 & $2.9 \mathrm{E}-06$ & 0.41 & $1.7 \mathrm{E}-06$ \\
14 & 40 & 0.35 & $1.5 \mathrm{E}-06$ & 0.18 & $7.4 \mathrm{E}-07$ \\
15 & 40 & 1.6 & $6.5 \mathrm{E}-06$ & 0.48 & $2.0 \mathrm{E}-06$ \\
16 & 41 & 0.78 & $3.3 \mathrm{E}-06$ & 0.21 & $8.8 \mathrm{E}-07$ \\
17 & 40 & 1.8 & $7.7 \mathrm{E}-06$ & 0.85 & $3.5 \mathrm{E}-06$ \\
18 & 41 & 0.20 & $8.6 \mathrm{E}-07$ & 0.04 & $1.5 \mathrm{E}-07$ \\
19 & 41 & 0.13 & $5.3 \mathrm{E}-07$ & 0.05 & $2.2 \mathrm{E}-07$ \\
20 & 41 & 0.32 & $1.3 \mathrm{E}-06$ & 0.25 & $1.0 \mathrm{E}-06$ \\
Blank & $\mathrm{NA}$ & & & & \\
Standard & $\mathrm{NA}$ & 0.53 & $2.2 \mathrm{E}-06$ & 0.58 & $2.4 \mathrm{E}-06$ \\
\hline
\end{tabular}


Table C.2 Pu and Am Solubility in Salt Solutions - Sample 2

\begin{tabular}{cccccc}
\hline \hline Solution & $\begin{array}{c}\text { Equilibration } \\
\text { Time } \\
(\text { days })\end{array}$ & $\begin{array}{c}\mathrm{Pu} \\
\text { Solubility } \\
(\mu \mathrm{g} / \mathrm{mL})\end{array}$ & $\begin{array}{c}\mathrm{Pu} \\
\text { Solubility } \\
(\mathrm{moles} / \mathrm{L})\end{array}$ & $\begin{array}{c}\text { Am } \\
\text { Solubility } \\
(\mu \mathrm{g} / \mathrm{mL})\end{array}$ & $\begin{array}{c}\text { Am } \\
\text { Solubility } \\
(\mathrm{moles} / \mathrm{L})\end{array}$ \\
\hline $1 \mathrm{~A}$ & 68 & 3.1 & $1.3 \mathrm{E}-05$ & 0.73 & $3.0 \mathrm{E}-06$ \\
$2 \mathrm{~A}$ & 69 & 4.5 & $1.9 \mathrm{E}-05$ & 1.2 & $4.8 \mathrm{E}-06$ \\
$3 \mathrm{~A}$ & 69 & 3.2 & $1.3 \mathrm{E}-05$ & 0.85 & $3.5 \mathrm{E}-06$ \\
4 & 68 & 1.9 & $7.8 \mathrm{E}-06$ & 0.90 & $3.7 \mathrm{E}-06$ \\
5 & 69 & 0.43 & $1.8 \mathrm{E}-06$ & 0.13 & $5.4 \mathrm{E}-07$ \\
6 & 69 & 0.55 & $2.3 \mathrm{E}-06$ & 0.32 & $1.3 \mathrm{E}-06$ \\
7 & 69 & 0.25 & $1.0 \mathrm{E}-06$ & 0.13 & $5.4 \mathrm{E}-07$ \\
8 & 68 & 1.6 & $6.5 \mathrm{E}-06$ & 1.17 & $4.8 \mathrm{E}-06$ \\
$9 \mathrm{~A}$ & 68 & 1.7 & $7.0 \mathrm{E}-06$ & 0.65 & $2.7 \mathrm{E}-06$ \\
$10 \mathrm{~A}$ & 69 & 0.81 & $3.4 \mathrm{E}-06$ & 0.55 & $2.3 \mathrm{E}-06$ \\
$11 \mathrm{~A}$ & 69 & 2.6 & $1.1 \mathrm{E}-05$ & 0.14 & $5.9 \mathrm{E}-07$ \\
12 & 68 & 2.6 & $1.1 \mathrm{E}-05$ & 1.0 & $4.3 \mathrm{E}-06$ \\
13 & 68 & 0.80 & $3.3 \mathrm{E}-06$ & 0.62 & $2.6 \mathrm{E}-06$ \\
14 & 68 & 0.08 & $3.4 \mathrm{E}-07$ & 0.0044 & $1.8 \mathrm{E}-08$ \\
15 & 68 & 1.8 & $7.4 \mathrm{E}-06$ & 1.0 & $4.2 \mathrm{E}-06$ \\
16 & 69 & 0.66 & $2.8 \mathrm{E}-06$ & 0.34 & $1.4 \mathrm{E}-06$ \\
17 & 68 & 1.6 & $6.5 \mathrm{E}-06$ & 0.79 & $3.3 \mathrm{E}-06$ \\
18 & 69 & 0.21 & $8.8 \mathrm{E}-07$ & 0.048 & $2.0 \mathrm{E}-07$ \\
19 & 69 & 0.11 & $4.5 \mathrm{E}-07$ & 0.058 & $2.4 \mathrm{E}-07$ \\
20 & 69 & 0.20 & $8.2 \mathrm{E}-07$ & 0.15 & $6.2 \mathrm{E}-07$ \\
Blank & & & & & \\
Standard & $\mathrm{NA}$ & negligible & negligible & negligible & negligible \\
& $\mathrm{NA}$ & 0.51 & $2.1 \mathrm{E}-06$ & 0.57 & $2.4 \mathrm{E}-06$ \\
\hline
\end{tabular}


Table C.3 Pu and Am Solubility in Salt Solutions - Sample 3

\begin{tabular}{cccccc}
\hline \hline Solution & $\begin{array}{c}\text { Equilibration } \\
\text { Time } \\
(\text { days })\end{array}$ & $\begin{array}{c}\mathrm{Pu} \\
\text { Solubility } \\
(\mu \mathrm{g} / \mathrm{mL})\end{array}$ & $\begin{array}{c}\text { Pu } \\
\text { Solubility } \\
(\text { moles/L) }\end{array}$ & $\begin{array}{c}\mathrm{Am} \\
\text { Solubility } \\
(\mu \mathrm{g} / \mathrm{mL})\end{array}$ & $\begin{array}{c}\text { Am } \\
\text { Solubility } \\
(\text { moles/L) }\end{array}$ \\
\hline $1 \mathrm{~A}$ & 96 & 2.8 & $1.2 \mathrm{E}-05$ & 1.1 & $4.6 \mathrm{E}-06$ \\
$2 \mathrm{~A}$ & 97 & 3.9 & $1.6 \mathrm{E}-05$ & 1.3 & $5.6 \mathrm{E}-06$ \\
$3 \mathrm{~A}$ & 97 & 3.6 & $1.5 \mathrm{E}-05$ & 0.96 & $4.0 \mathrm{E}-06$ \\
4 & 96 & 1.7 & $7.2 \mathrm{E}-06$ & 1.3 & $5.4 \mathrm{E}-06$ \\
5 & 97 & 2.1 & $8.8 \mathrm{E}-06$ & 1.8 & $7.4 \mathrm{E}-06$ \\
6 & 97 & 0.40 & $1.7 \mathrm{E}-06$ & 0.19 & $7.8 \mathrm{E}-07$ \\
7 & 97 & 0.17 & $7.1 \mathrm{E}-07$ & 0.082 & $3.4 \mathrm{E}-07$ \\
8 & 96 & 0.94 & $3.9 \mathrm{E}-06$ & 0.41 & $1.7 \mathrm{E}-06$ \\
$9 \mathrm{~A}$ & 96 & 2.1 & $9.0 \mathrm{E}-06$ & 1.5 & $6.0 \mathrm{E}-06$ \\
$10 \mathrm{~A}$ & 97 & 0.77 & $3.2 \mathrm{E}-06$ & 0.57 & $2.4 \mathrm{E}-06$ \\
$11 \mathrm{~A}$ & 97 & 2.5 & $1.0 \mathrm{E}-05$ & 0.72 & $3.0 \mathrm{E}-06$ \\
12 & 96 & 2.0 & $8.6 \mathrm{E}-06$ & 0.79 & $3.3 \mathrm{E}-06$ \\
13 & 96 & 0.43 & $1.8 \mathrm{E}-06$ & 0.28 & $1.2 \mathrm{E}-06$ \\
14 & 96 & 0.26 & $1.1 \mathrm{E}-06$ & 0.23 & $9.4 \mathrm{E}-07$ \\
15 & 96 & 1.40 & $5.9 \mathrm{E}-06$ & 0.71 & $3.0 \mathrm{E}-06$ \\
16 & 97 & 0.54 & $2.3 \mathrm{E}-06$ & 0.27 & $1.1 \mathrm{E}-06$ \\
17 & 96 & 2.1 & $8.8 \mathrm{E}-06$ & 0.77 & $3.2 \mathrm{E}-06$ \\
18 & 97 & 0.15 & $6.3 \mathrm{E}-07$ & 0.046 & $1.9 \mathrm{E}-07$ \\
19 & 97 & 0.13 & $5.5 \mathrm{E}-07$ & 0.12 & $4.8 \mathrm{E}-07$ \\
20 & 97 & 0.24 & $9.9 \mathrm{E}-07$ & 0.18 & $7.6 \mathrm{E}-07$ \\
& & & & & \\
Blank & NA & negligible & negligible & negligible & negligible \\
Standard & NA & 0.48 & $2.0 \mathrm{E}-06$ & 0.55 & $2.3 \mathrm{E}-06$ \\
\hline
\end{tabular}

The blank solutions analyzed with each sample set showed negligible amounts of both $\mathrm{Pu}$ and Am. The analysis of the standard Pu and Am solutions are compared with the known concentration in Table C.4.

Table C.4 Comparison of Analyzed Pu and Am Concentrations with Prepared Values

\begin{tabular}{ccccccc}
\hline \hline $\begin{array}{c}\text { Data } \\
\text { Set }\end{array}$ & $\begin{array}{c}\text { Pu } \\
\text { Prepared } \\
\text { Conc }\end{array}$ & $\begin{array}{c}\text { Pu } \\
\text { Measured } \\
\text { Conc }\end{array}$ & $\begin{array}{c}\text { Percent } \\
\text { Difference }\end{array}$ & $\begin{array}{c}\text { Am } \\
\text { Prepared } \\
\text { Conc }\end{array}$ & $\begin{array}{c}\text { Am } \\
\text { Measured } \\
\text { Conc }\end{array}$ & $\begin{array}{c}\text { Percent } \\
\text { Difference }\end{array}$ \\
\hline & $(\mu / \mathrm{g} / \mathrm{mL})$ & $(\mu / \mathrm{g} / \mathrm{mL})$ & $(\%)$ & $(\mu / \mathrm{g} / \mathrm{mL})$ & $(\mu / \mathrm{g} / \mathrm{mL})$ & $(\%)$ \\
1 & 0.50 & 0.53 & 6.0 & 0.50 & 0.58 & 16 \\
2 & 0.50 & 0.51 & 2.0 & 0.50 & 0.57 & 14 \\
3 & 0.50 & 0.48 & -4.0 & 0.50 & 0.55 & 10 \\
\hline
\end{tabular}


The measured $\mathrm{Pu}$ concentrations are within nominally $\pm 5 \%$ of the prepared concentration which is typically the accuracy of the TTA/APHA method. The measured Am concentrations appear biased high based on the prepared concentration; although, they are reasonably consistent. The bias can likely be attributed to a concentration in the standard which was slightly higher than $1000 \mu \mathrm{g} / \mathrm{mL}$. This could be attributed to a higher than measured concentration in the purified Am solution used to prepare the standard or the multiple transfers of the purified Am solution with a variable volume pipette in a radioactive glovebox which were required to prepare the standard. 


\section{Appendix D Statistical Exhibits}

Exhibit D.1 Plots of Pu and Am Solubility Data by Sample Number

Trial ID=1A

Pu (M) By Sample
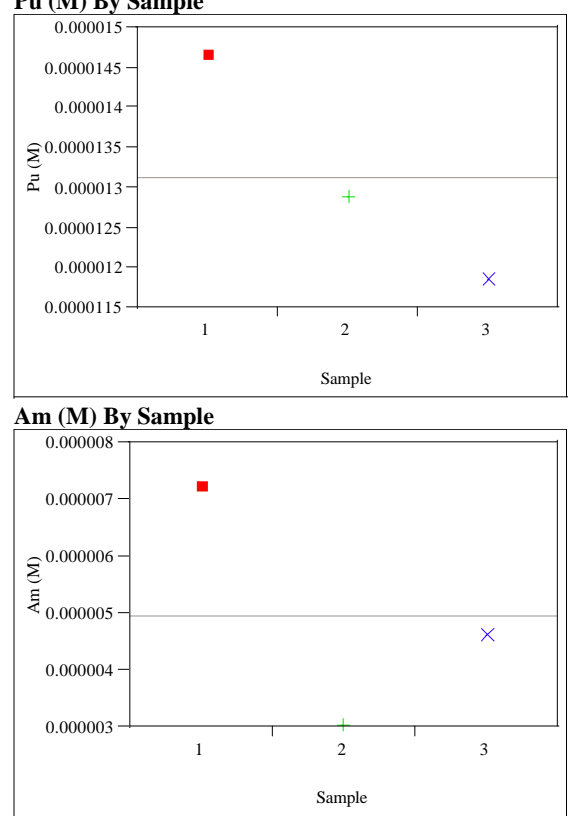

Sample

Trial ID=2A

Pu (M) By Sample

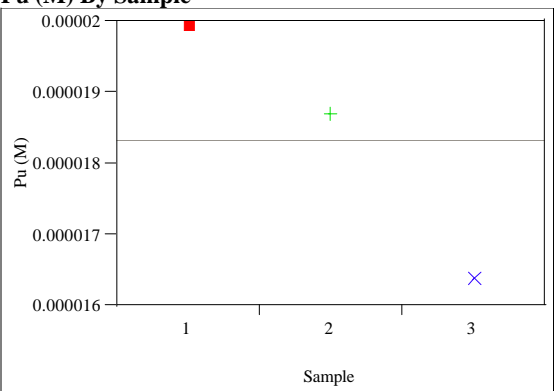

Am (M) By Sample

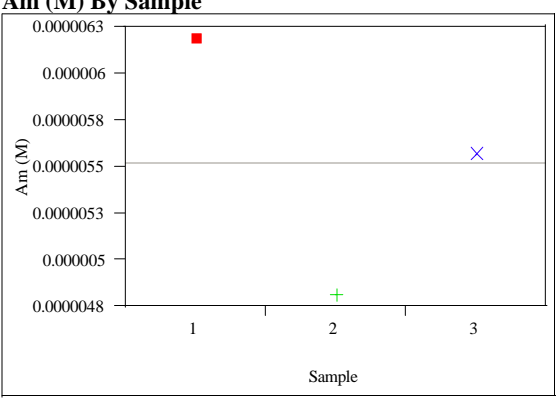

Trial ID=3A

Pu (M) By Sample
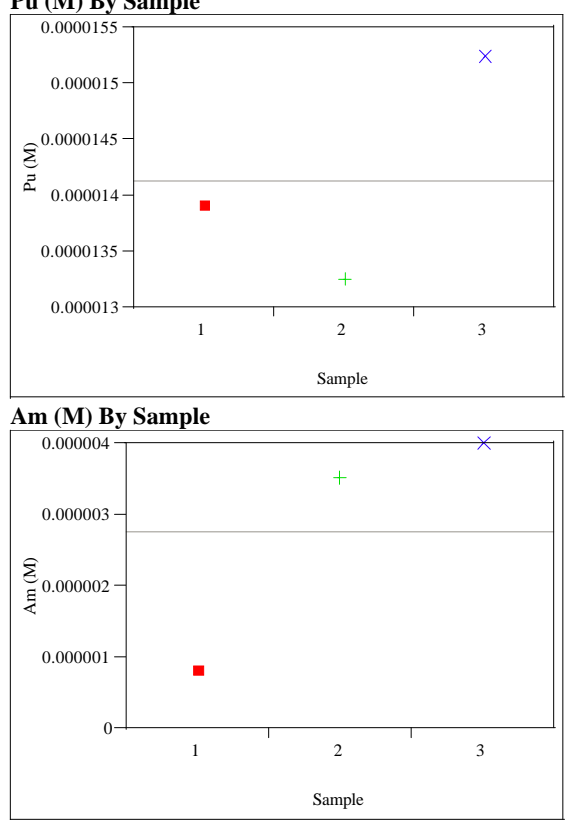

Trial ID $=4$

Pu (M) By Sample

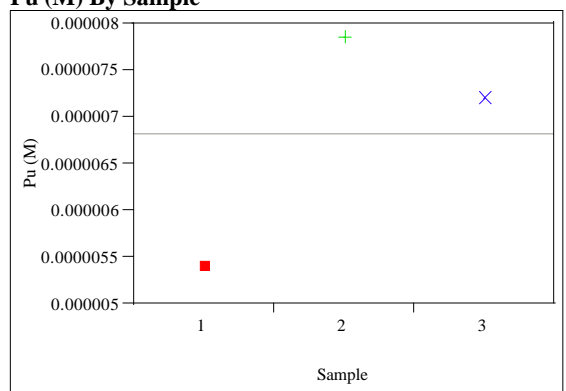

Am (M) By Sample

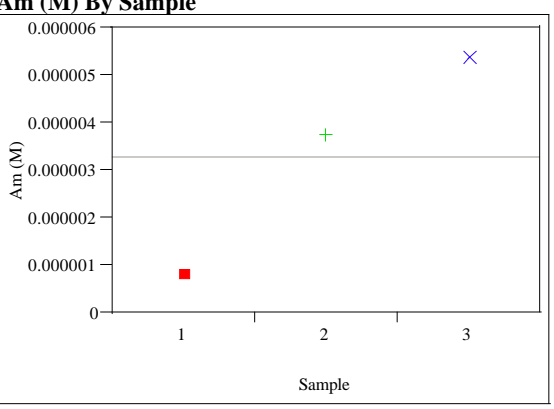

Trial ID=5

Pu (M) By Sample

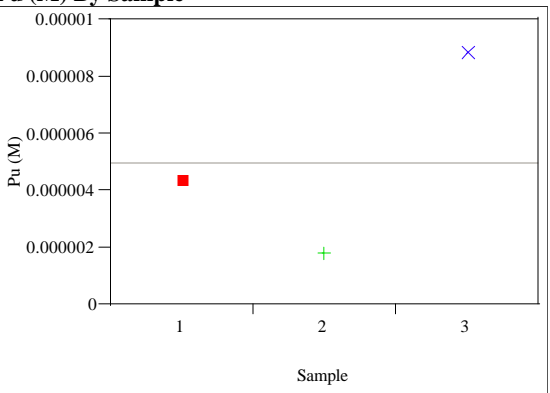

Am (M) By Sample

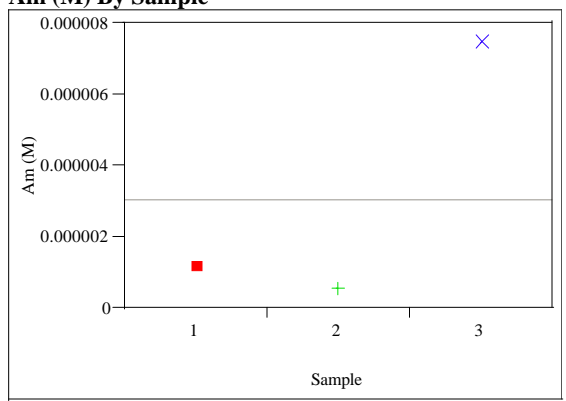

Trial ID=6

Pu (M) By Sample

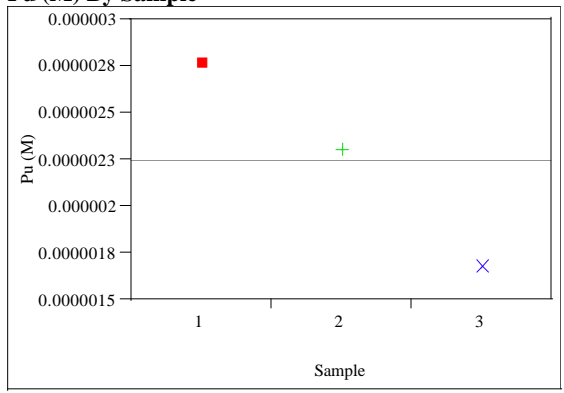

Am (M) By Sample

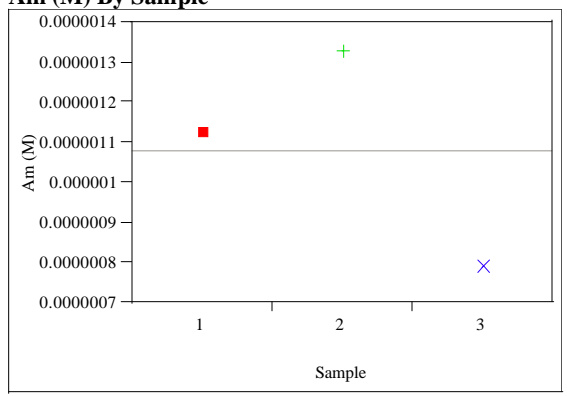


WSRC-TR-2004-00349

Revision 0

Exhibit D.1 Plots of Pu and Am Solubility Data by Sample Number (continued)

Trial ID=7

Pu (M) By Sample

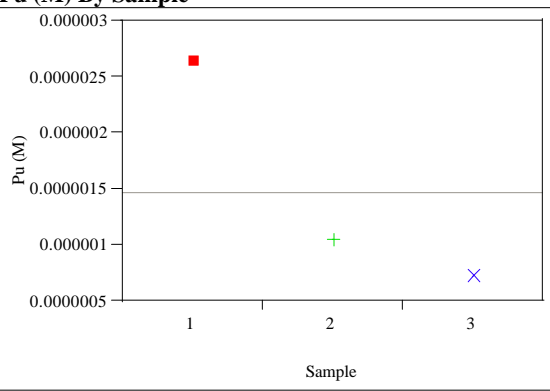

Am (M) By Sample

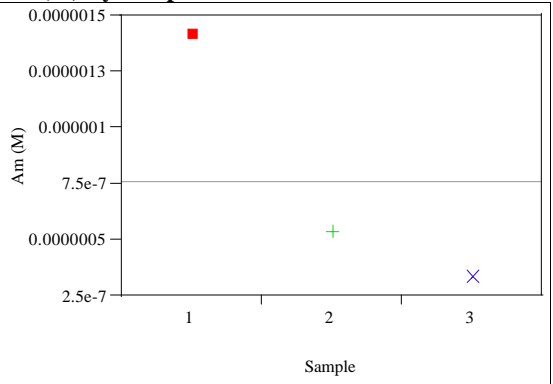

Trial ID $=8$

Pu (M) By Sample

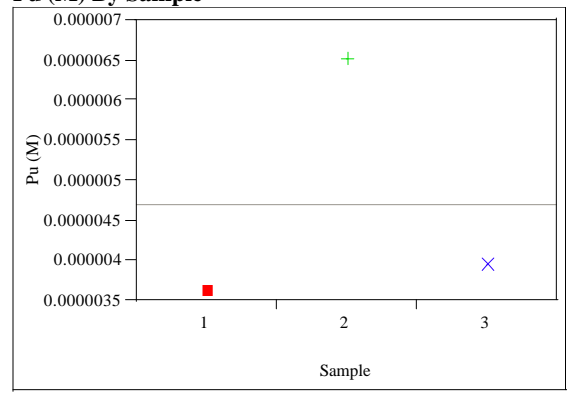

Am (M) By Sample

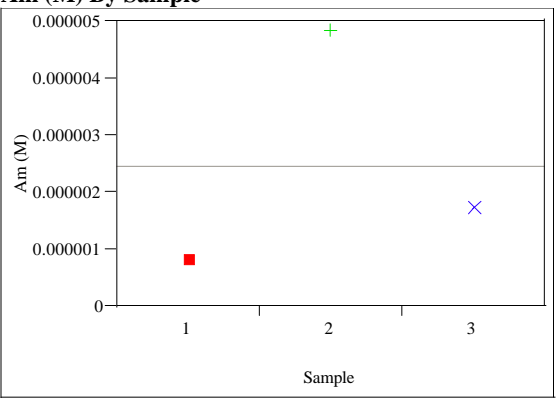

Trial ID=9A

Pu (M) By Sample
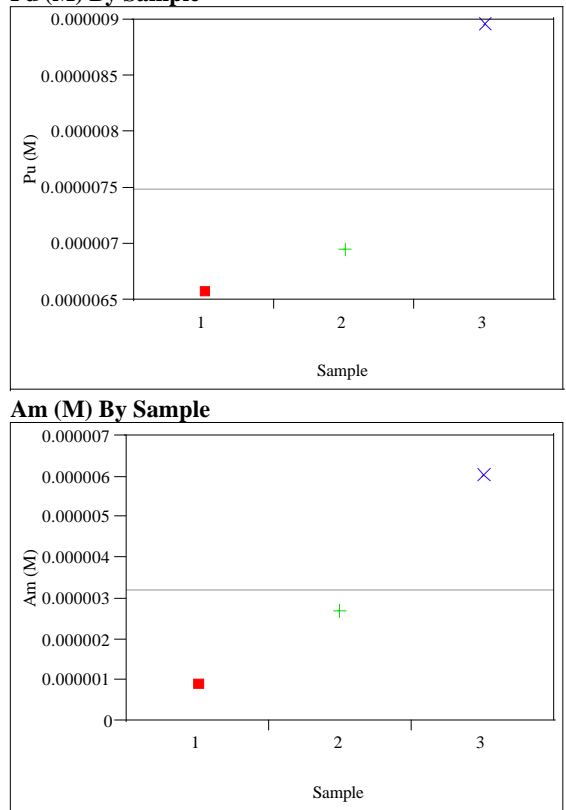

Trial ID=10A

Pu (M) By Sample

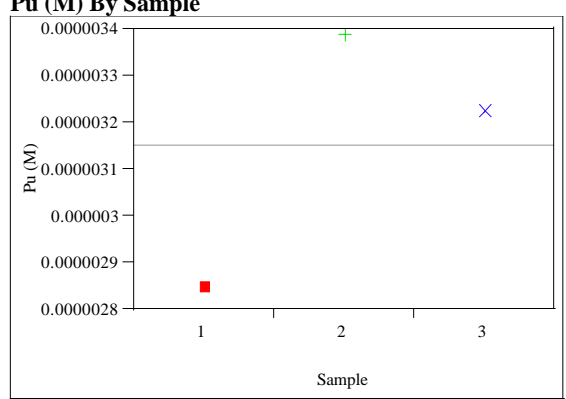

Am (M) By Sample

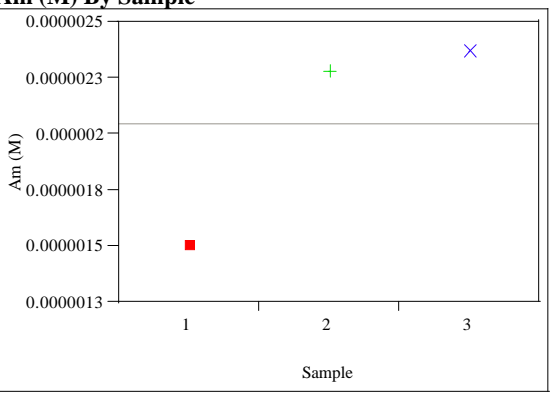

Trial ID=11A

Pu (M) By Sample

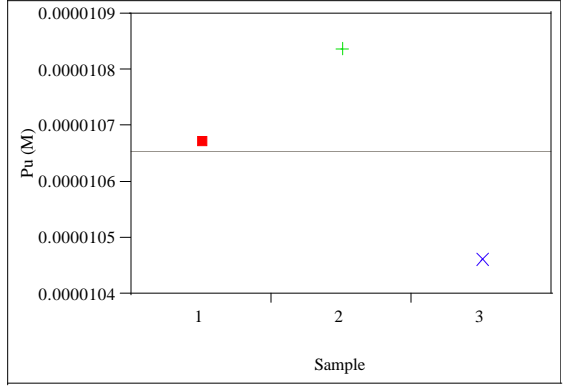

Am (M) By Sample

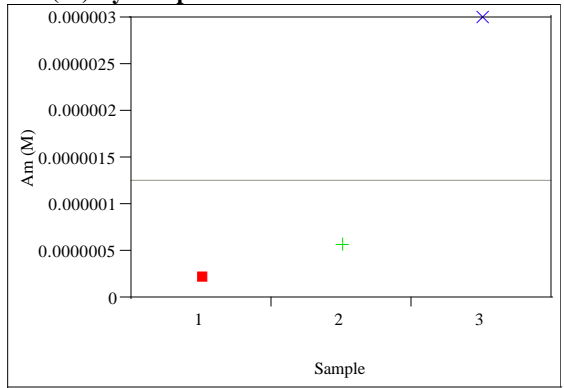

Trial ID=12

Pu (M) By Sample

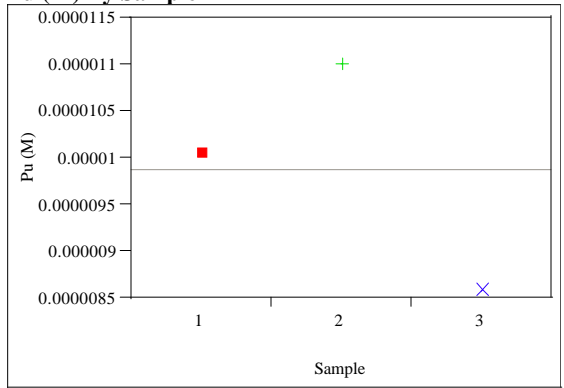

Am (M) By Sample

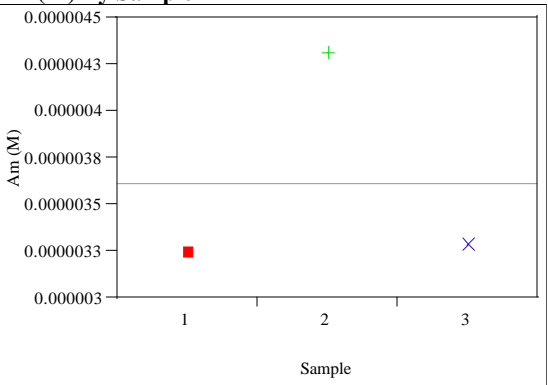


WSRC-TR-2004-00349

Revision 0

Exhibit D.1 Plots of Pu and Am Solubility Data by Sample Number (continued)

Trial ID=13

Pu (M) By Sample

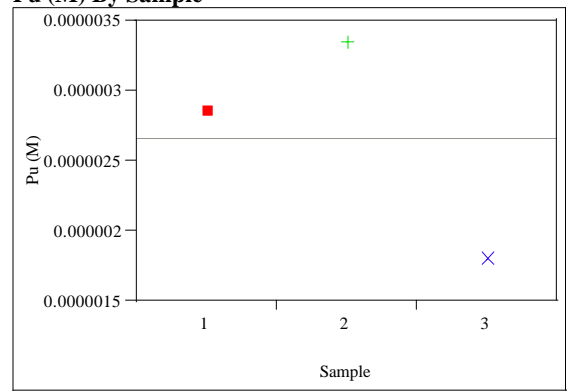

Am (M) By Sample

Trial ID $=15$

Pu (M) By Sample
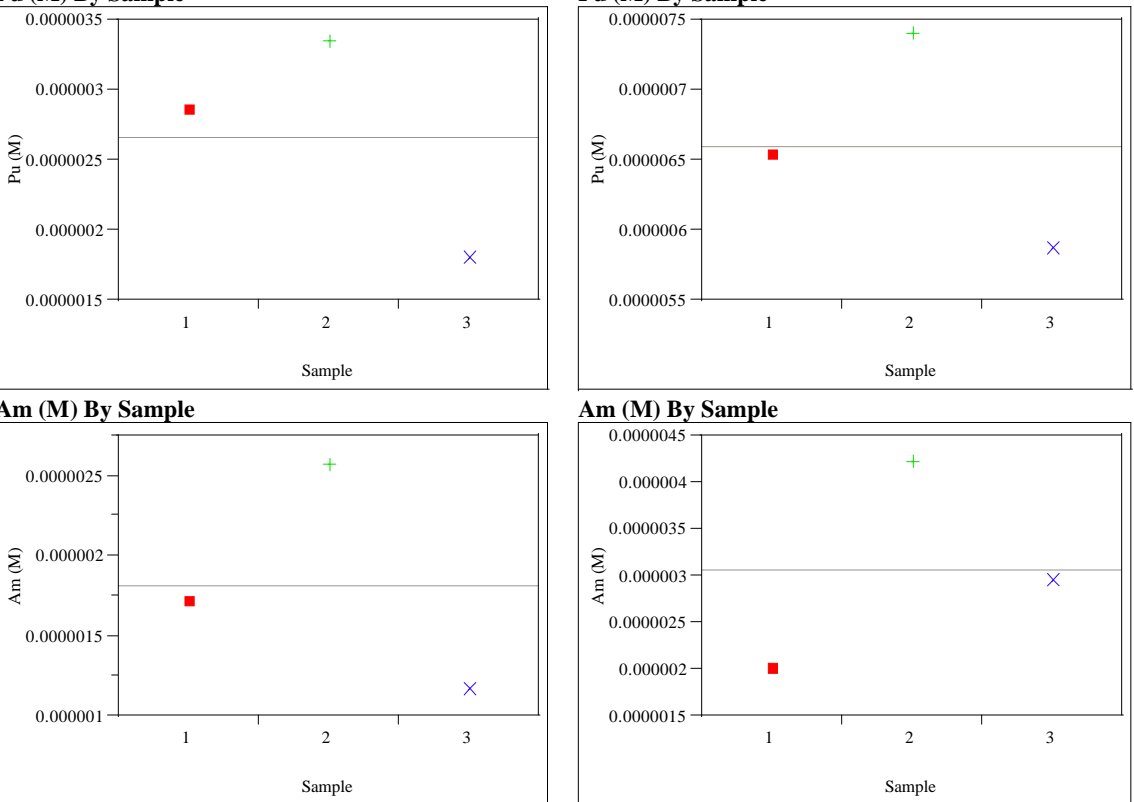

Am (M) By Sample

Trial ID=17

Pu (M) By Sample
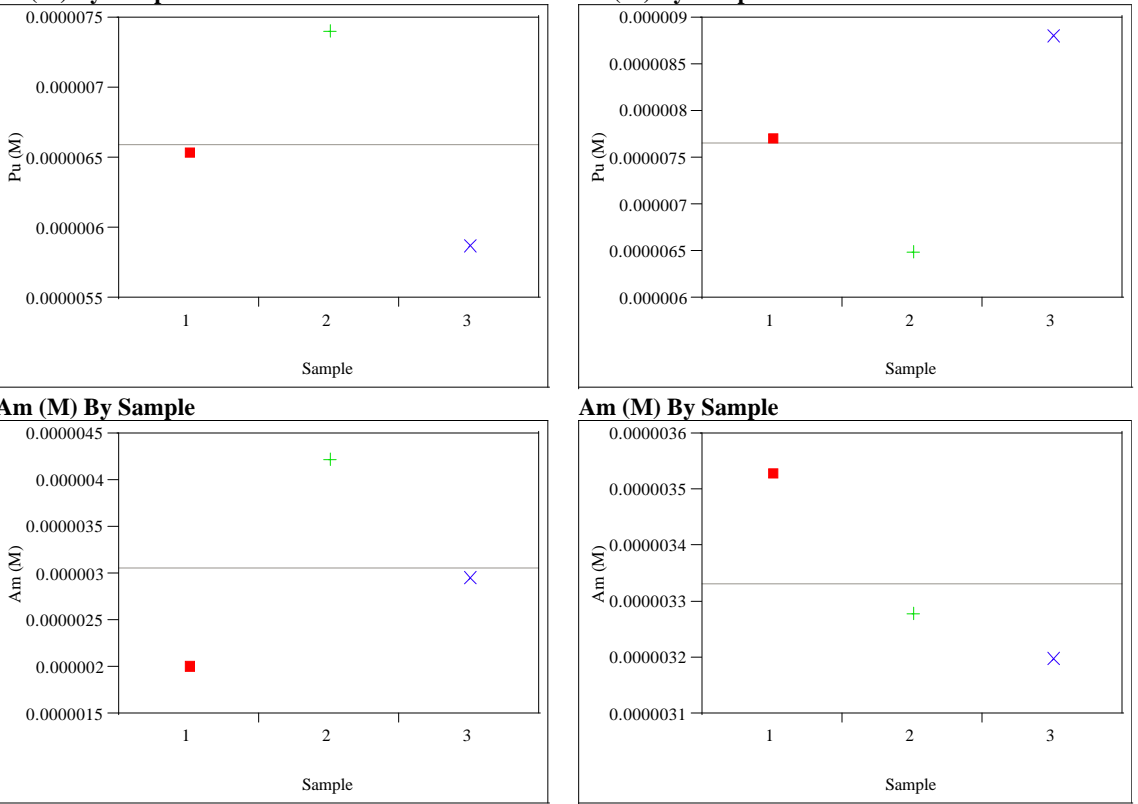

Am (M) By Sample

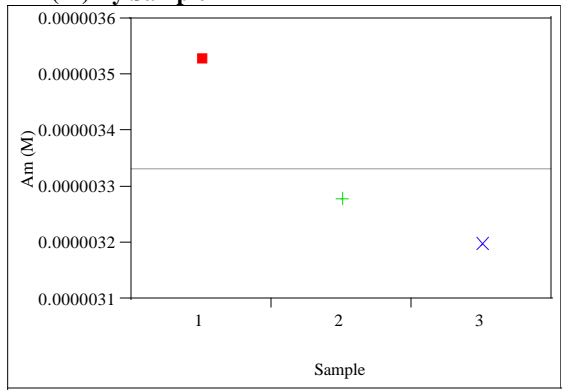

Trial ID=14

Pu (M) By Sample

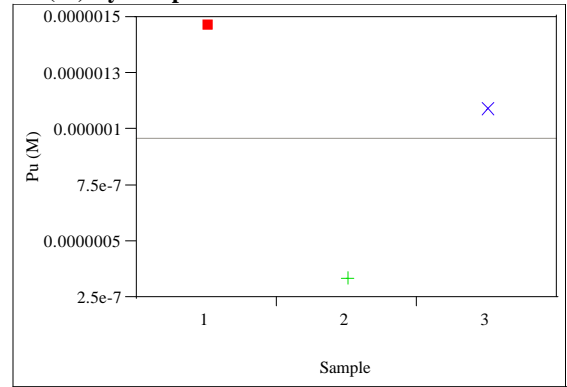

Am (M) By Sample

Pu (M) By Sample
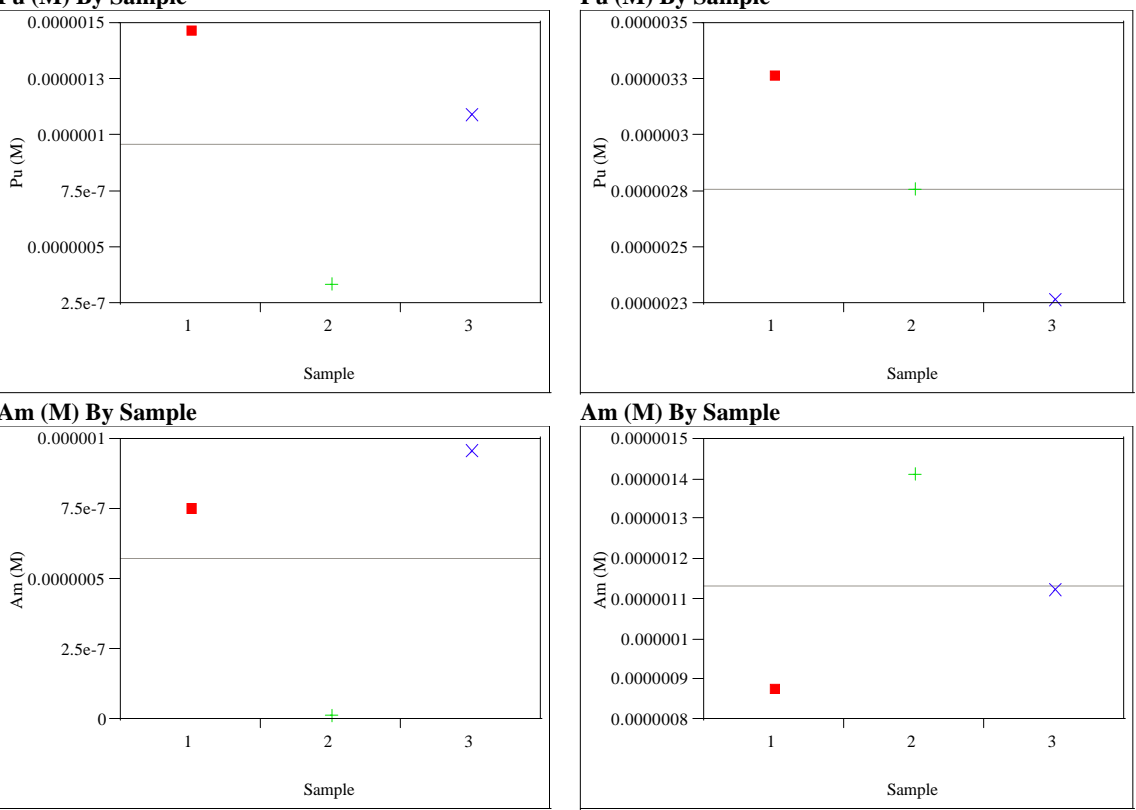

Am (M) By Sample
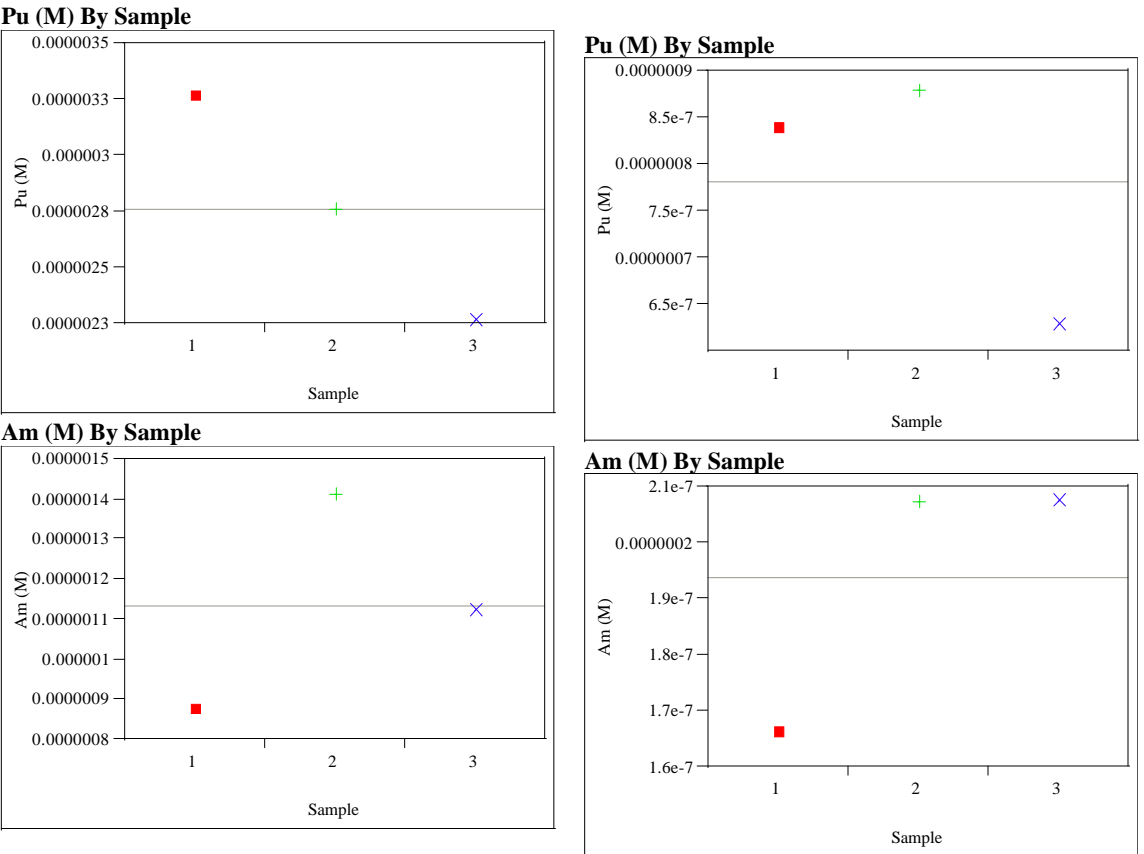
Exhibit D.1 Plots of Pu and Am Solubility Data by Sample Number (continued)

Trial ID=19

Pu (M) By Sample

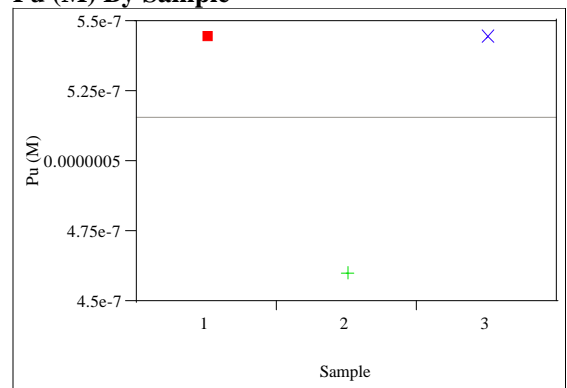

Am (M) By Sample

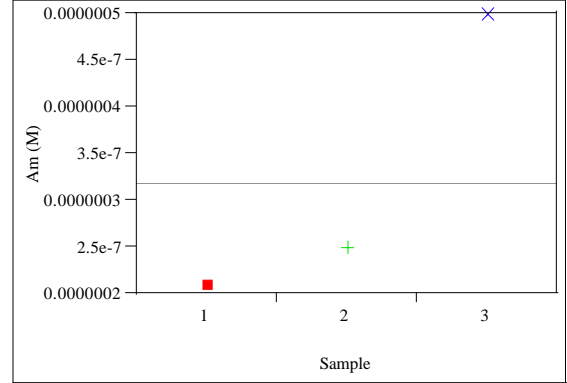

Trial ID $=20$

Pu (M) By Sample

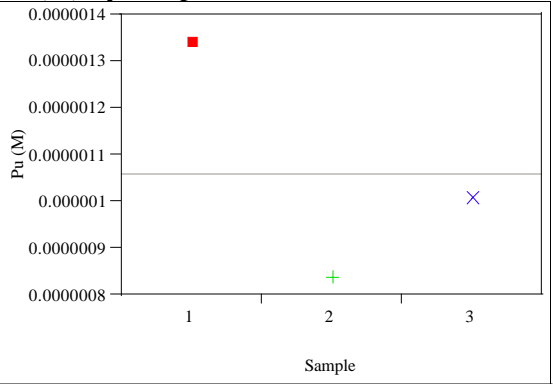

Am (M) By Sample

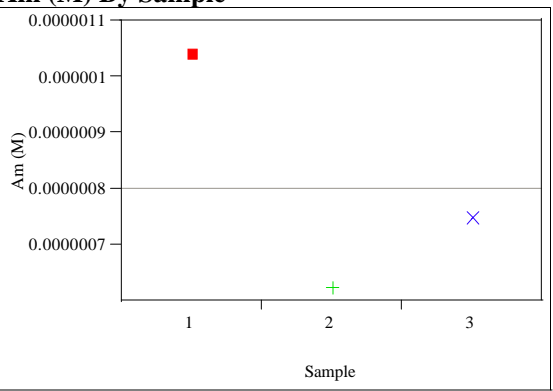


Exhibit D.2 Plots of Pu and Am Solubility Data (Each Sample and Average) by Each Factor
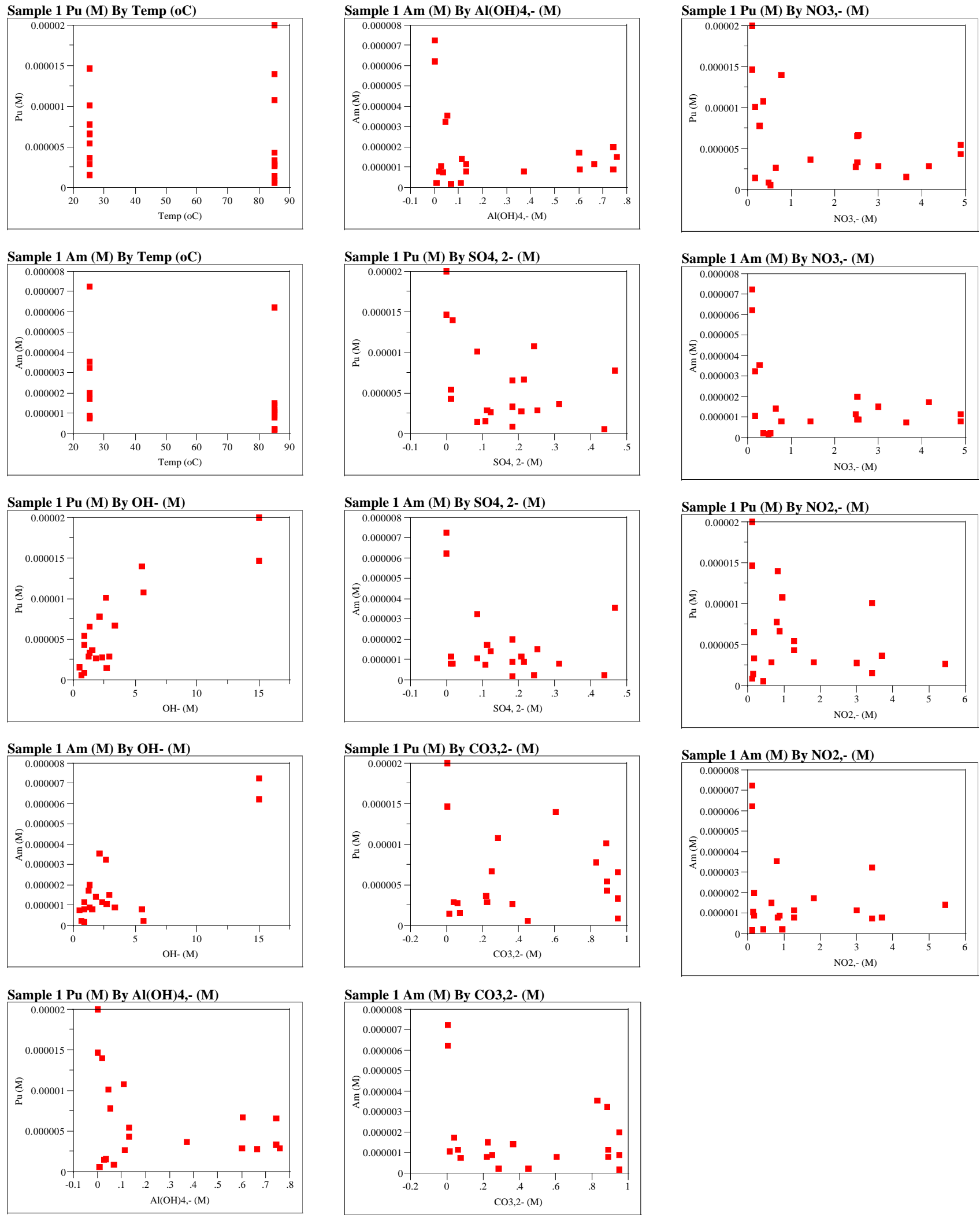
WSRC-TR-2004-00349

Revision 0

Exhibit D.2 Plots of Pu and Am Solubility Data (Each Sample and Average) by Each Factor (continued)

Sample 2 Pu (M) By Temp (oC)

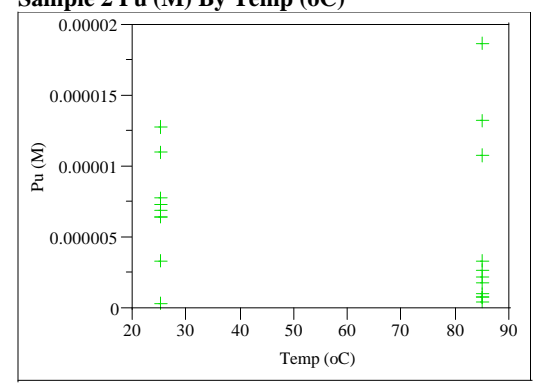

Sample 2 Am (M) By Temp (oC)

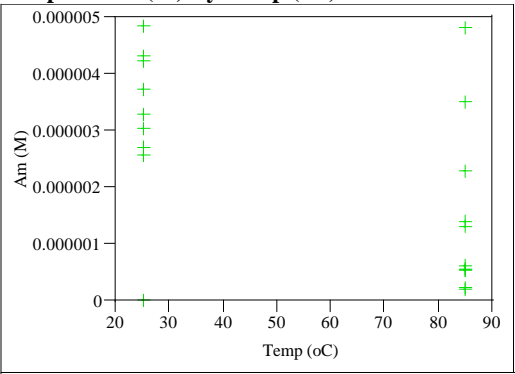

Sample 2 Pu (M) By OH- (M)

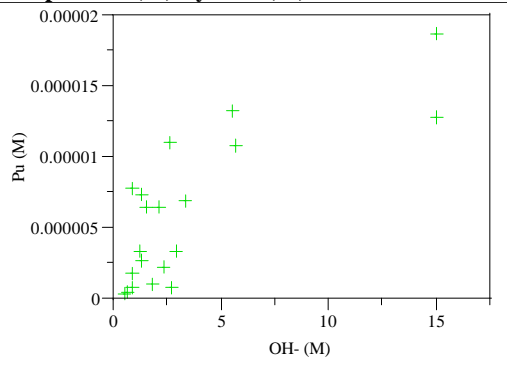

Sample 2 Am (M) By OH- (M)

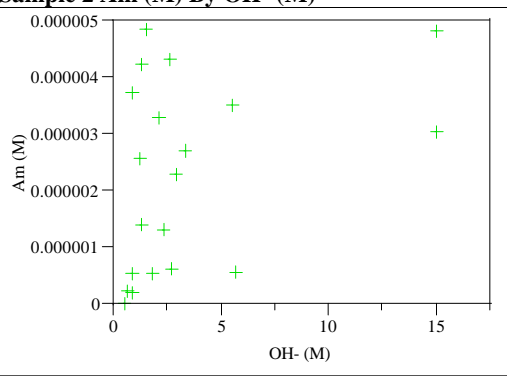

Sample 2 Pu (M) By Al(OH)4,- (M)

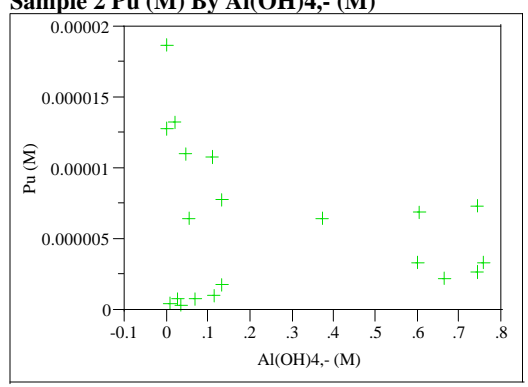

Sample 2 Am (M) By Al(OH)4,- (M)

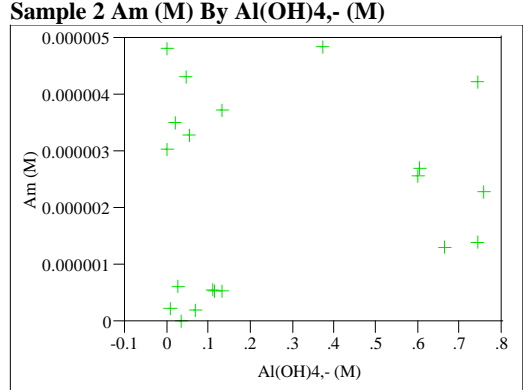

Sample 2 Pu (M) By SO4, 2- (M)

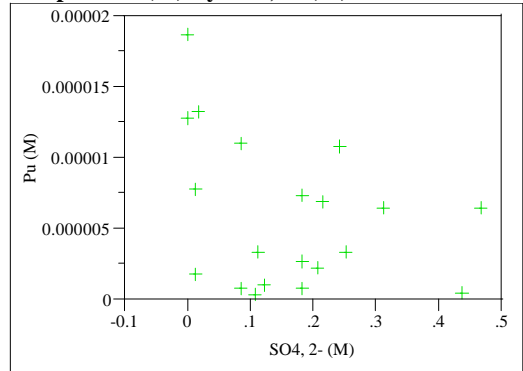

Sample 2 Am (M) By SO4, 2- (M)

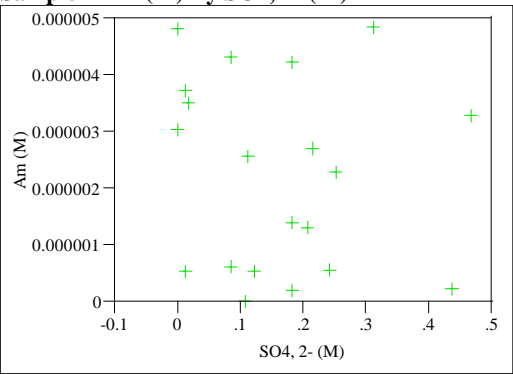

Sample 2 Pu (M) By CO3,2- (M)

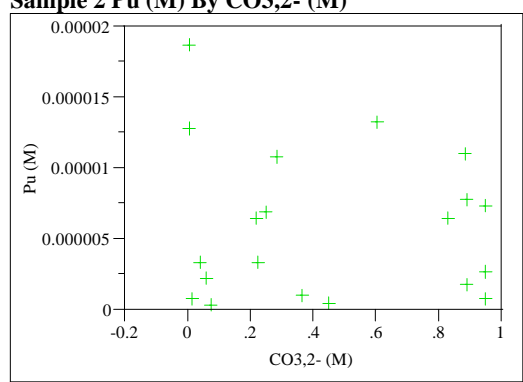

Sample 2 Am (M) By CO3,2- (M)

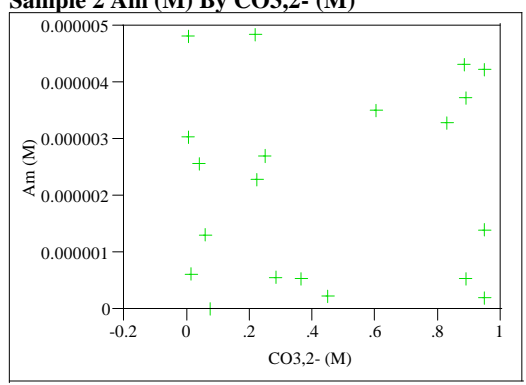

Sample 2 Pu (M) By NO3,- (M)

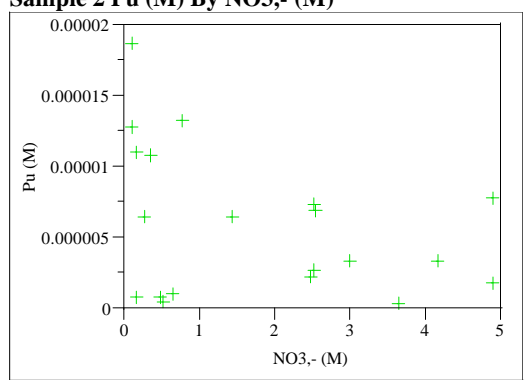

Sample 2 Am (M) By NO3,- (M)

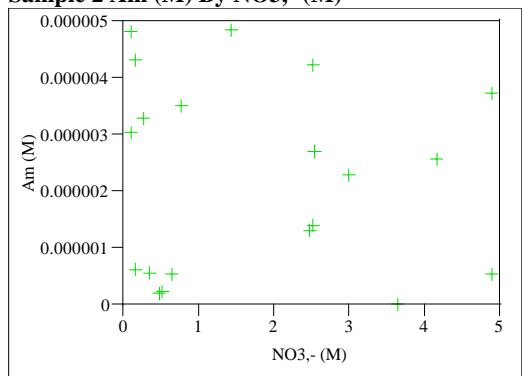

Sample 2 Pu (M) By NO2,- (M)
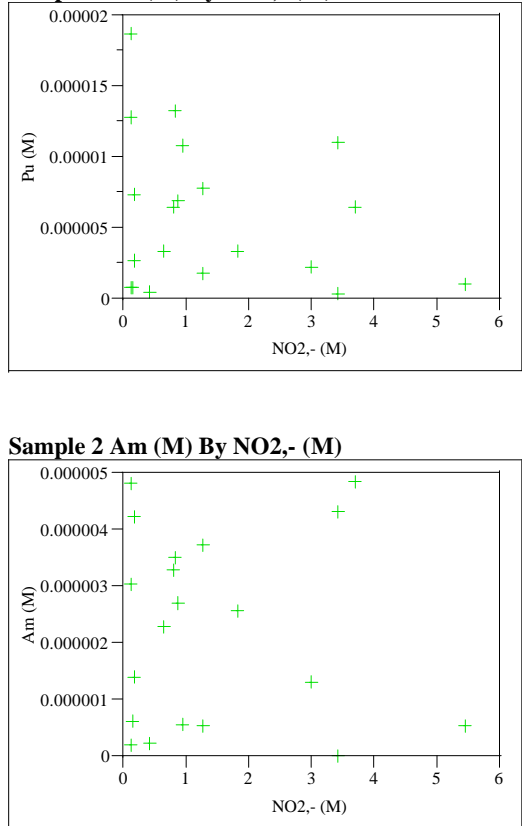
WSRC-TR-2004-00349

Revision 0

Exhibit D.2 Plots of Pu and Am Solubility Data (Each Sample and Average) by Each Factor (continued)

Sample 3 Pu (M) By Temp (oC)

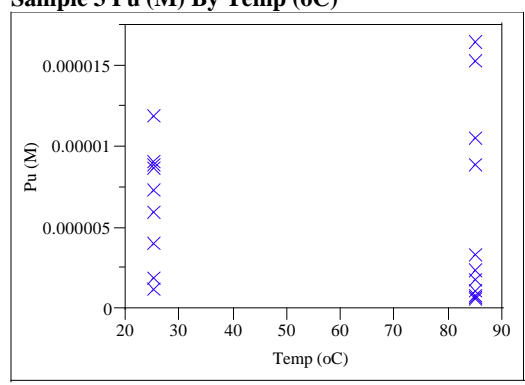

Sample 3 Am (M) By Temp (oC)

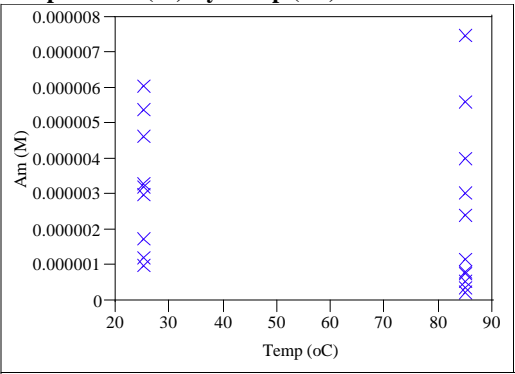

Sample 3 Pu (M) By OH- (M)
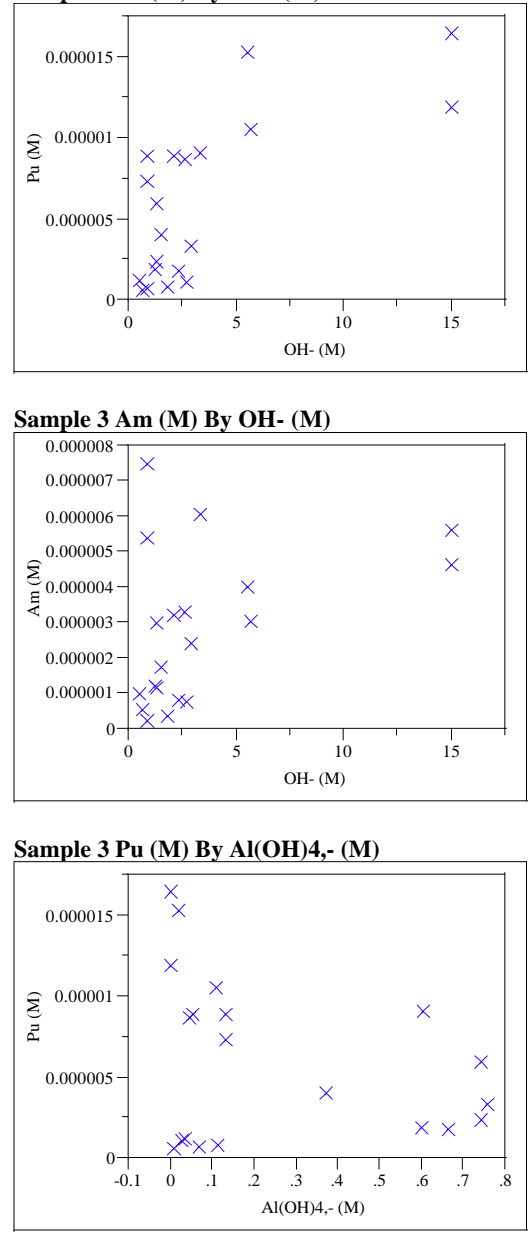

Sample $3 \mathrm{Am}(\mathrm{M})$ By $\mathrm{Al}(\mathrm{OH}) 4,-(\mathrm{M})$
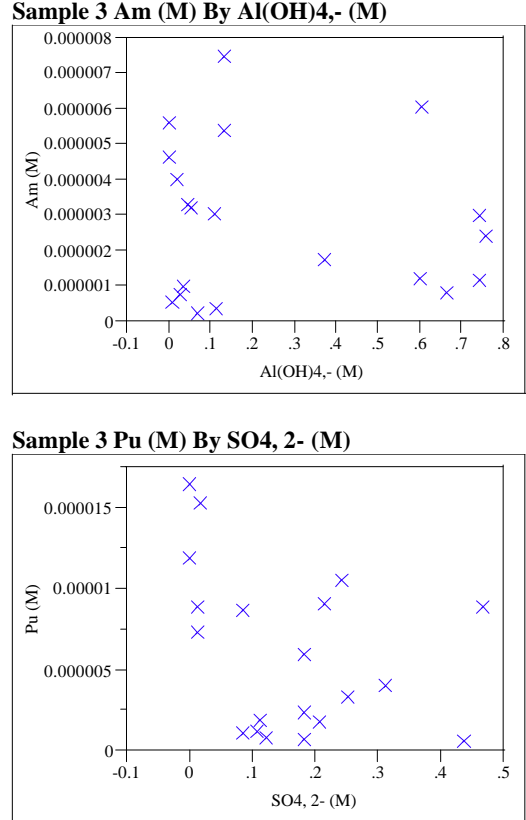

Sample 3 Am (M) By SO4, 2- (M)

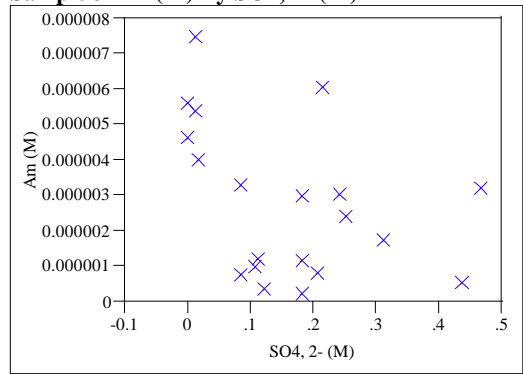

Sample 3 Pu (M) By CO3,2- (M)

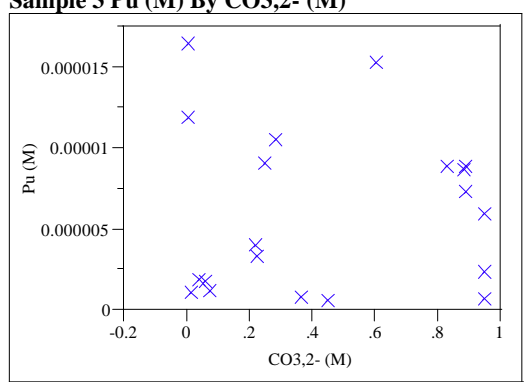

Sample 3 Am (M) By CO3,2- (M)

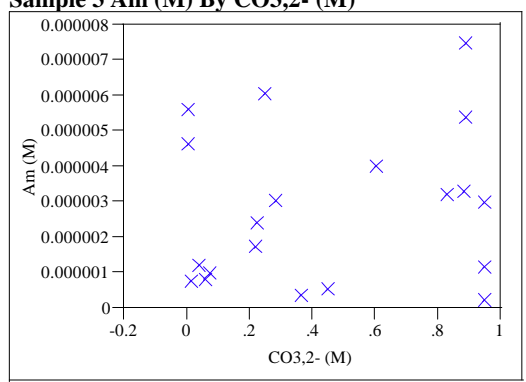

Sample 3 Pu (M) By NO3,- (M)

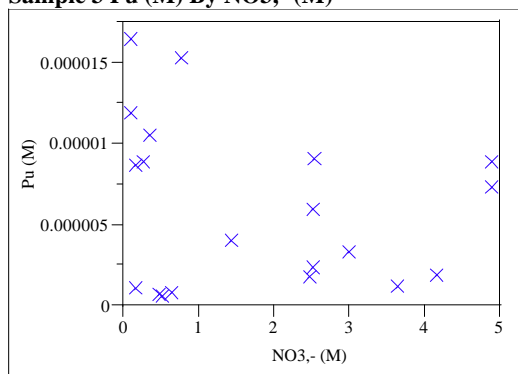

Sample 3 Am (M) By NO3,- (M)

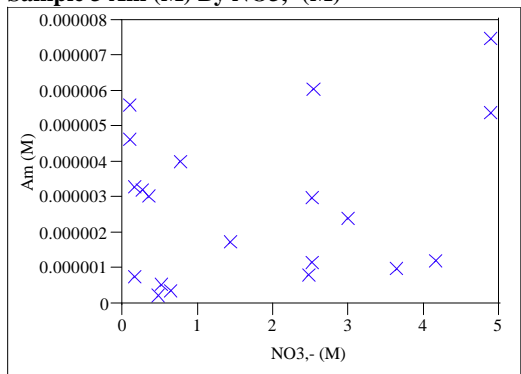

Sample 3 Pu (M) By NO2,- (M)
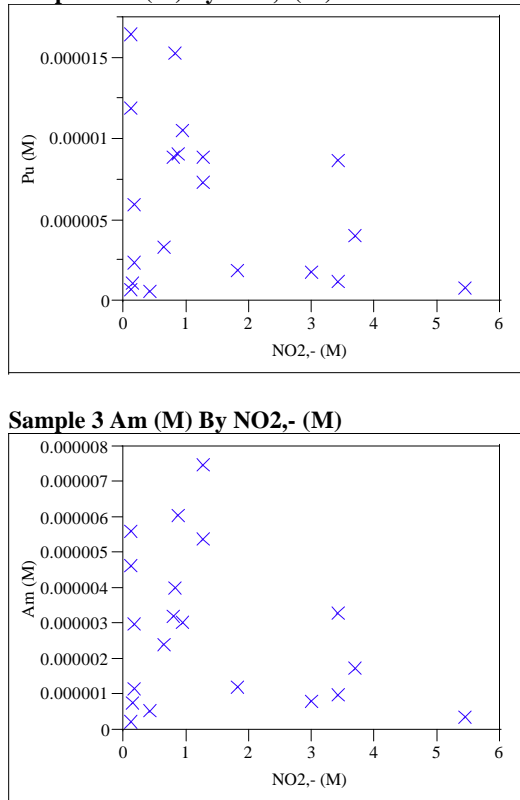
WSRC-TR-2004-00349

Revision 0

Exhibit D.2 Plots of Pu and Am Solubility Data (Each Sample and Average) by Each Factor (continued)

Sample Average Pu (M) By Temp (oC)

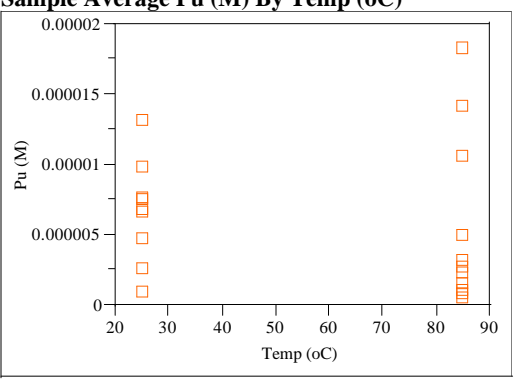

Sample Average Am (M) By Temp (oC)

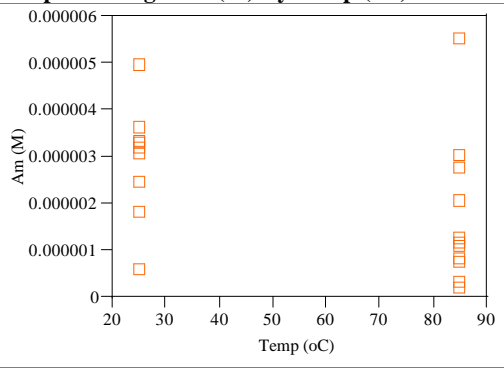

Sample Average Pu (M) By OH- (M)

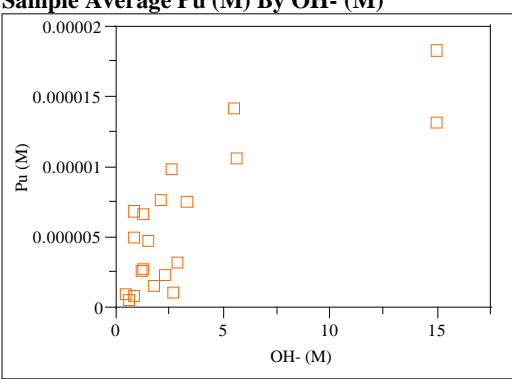

Sample Average Am (M) By OH- (M)

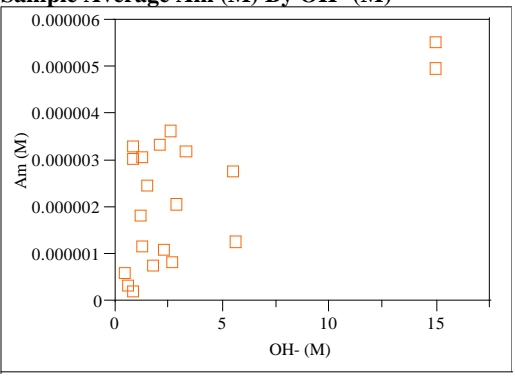

Sample Average Pu (M) By Al(OH)4,- (M)

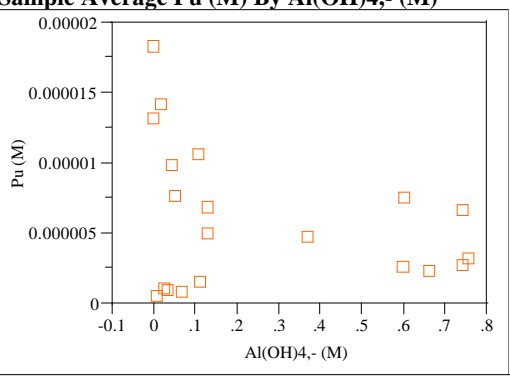

Sample Average Am (M) By Al(OH)4,- (M)

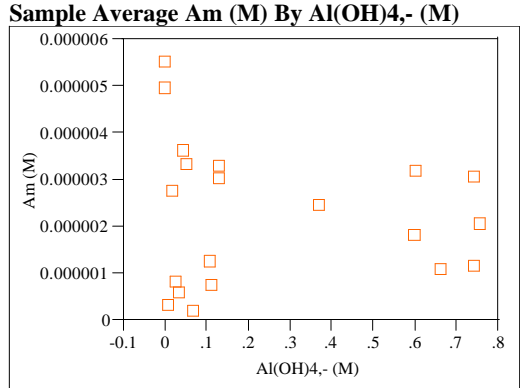

Sample Average Pu (M) By SO4, 2- (M)

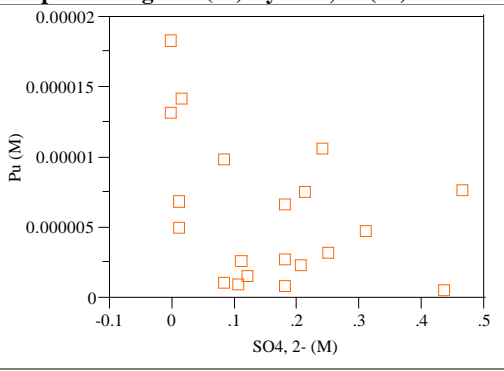

Sample Average Am (M) By SO4, 2- (M)

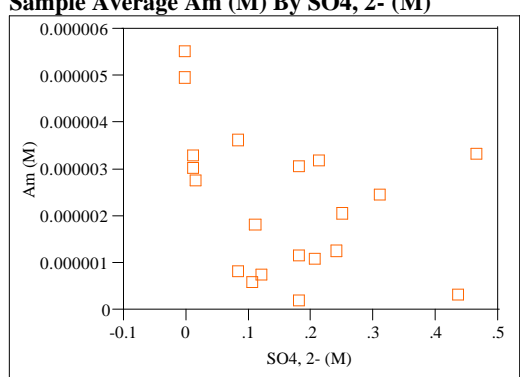

Sample Average Pu (M) By CO3,2- (M)

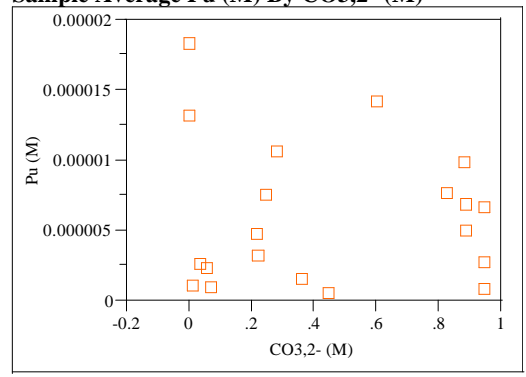

Sample Average Am (M) By CO3,2- (M)

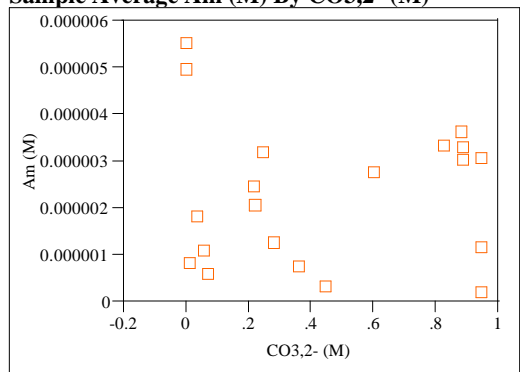

Sample Average Pu (M) By NO3,- (M)

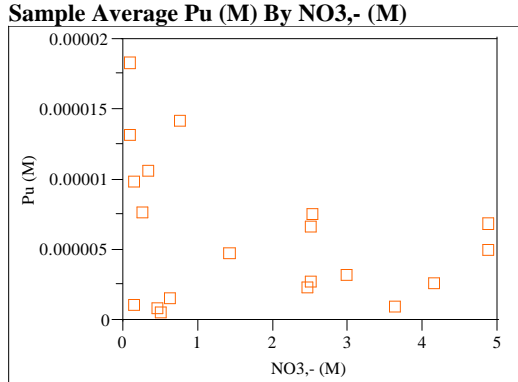

Sample Average Am (M) By NO3,- (M)

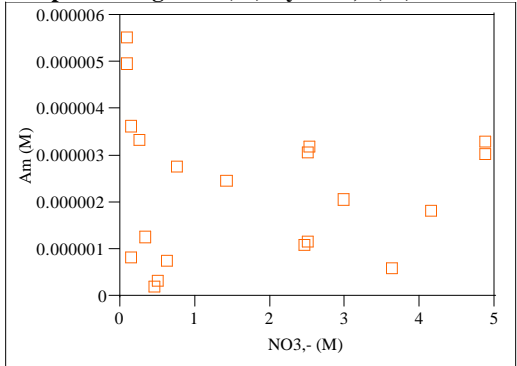

Sample Average Pu (M) By NO2,- (M)

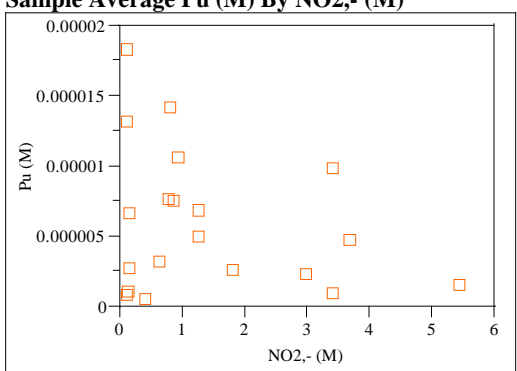

Sample Average Am (M) By NO2,- (M)

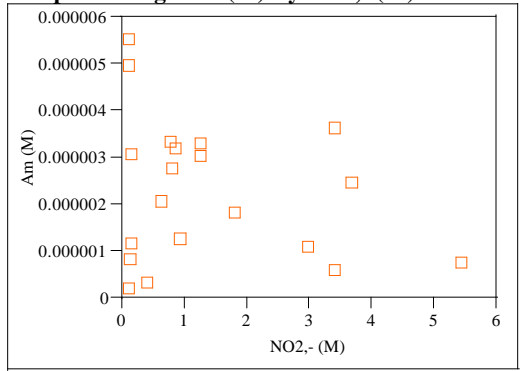


Exhibit D.3 First-Order Fits of the Am and Pu Solubility Data for Each Sample and the Average

Response Sample 1 Pu (M)

Actual by Predicted Plot

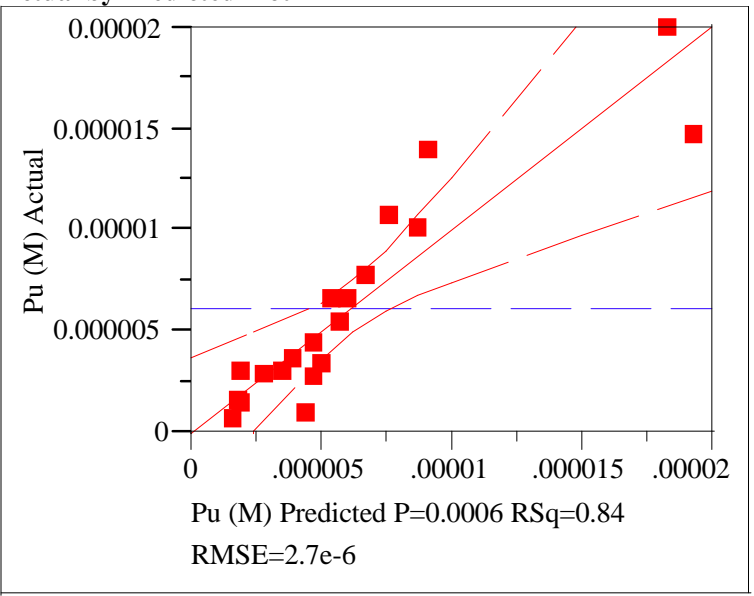

Summary of Fit

\begin{tabular}{|c|c|c|c|c|c|}
\hline \multicolumn{3}{|l|}{ RSquare } & \multicolumn{3}{|l|}{0.84023} \\
\hline \multicolumn{3}{|c|}{ RSquare Adj } & \multicolumn{3}{|c|}{0.747031} \\
\hline \multicolumn{3}{|c|}{ Root Mean Square Error } & \multicolumn{3}{|c|}{0.000003} \\
\hline \multicolumn{3}{|c|}{ Mean of Response } & \multicolumn{3}{|c|}{0.000006} \\
\hline \multicolumn{3}{|c|}{ Observations (or Sum Wgts) } & \multicolumn{3}{|l|}{20} \\
\hline \multicolumn{6}{|c|}{ Analysis of Variance } \\
\hline Source & $\mathrm{DF}$ & Sum of Squares & Mean Square & \multicolumn{2}{|c|}{ F Ratio } \\
\hline Model & 7 & $4.4451 \mathrm{e}-10$ & $6.35 \mathrm{e}-11$ & \multicolumn{2}{|c|}{9.0154} \\
\hline Error & 12 & $8.4524 \mathrm{e}-11$ & $7.044 \mathrm{e}-12$ & \multicolumn{2}{|c|}{ Prob $>\mathrm{F}$} \\
\hline C. Total & 19 & $5.2904 \mathrm{e}-10$ & & 0.0 & 06 \\
\hline \multicolumn{6}{|c|}{ Parameter Estimates } \\
\hline \multicolumn{3}{|c|}{ Term } & Std Error & t Ratio & $\operatorname{Prob}>|t|$ \\
\hline \multicolumn{2}{|l|}{ Intercept } & $-3.793 e-$ & 0.000004 & -0.09 & 0.9276 \\
\hline \multicolumn{2}{|c|}{ Temp (oC) } & $-1.676 \mathrm{e}-$ & $2.167 \mathrm{e}-8$ & -0.77 & 0.4542 \\
\hline \multicolumn{2}{|c|}{$\mathrm{OH}-(\mathrm{M})$} & 0.000001 & $2.713 \mathrm{e}-7$ & 4.90 & 0.0004 \\
\hline \multicolumn{2}{|c|}{$\mathrm{Al}(\mathrm{OH}) 4,-(\mathrm{M})$} & $-1.743 \mathrm{e}-$ & 0.000003 & -0.07 & 0.9466 \\
\hline \multicolumn{2}{|c|}{$\mathrm{SO} 4,2-(\mathrm{M})$} & $1.2052 \mathrm{e}-$ & 0.000007 & 0.02 & 0.9857 \\
\hline \multicolumn{2}{|c|}{$\mathrm{CO} 3,2-(\mathrm{M})$} & 0.000005 & 0.000002 & 2.52 & 0.0267 \\
\hline \multicolumn{2}{|c|}{ NO3,- (M) } & $4.2463 \mathrm{e}-$ & $6.002 \mathrm{e}-7$ & 0.07 & 0.9448 \\
\hline \multicolumn{2}{|c|}{$\mathrm{NO} 2,-(\mathrm{M})$} & $4.078 \mathrm{e}-$ & $4.968 \mathrm{e}-7$ & 0.82 & 0.4277 \\
\hline
\end{tabular}

Residual by Predicted Plot

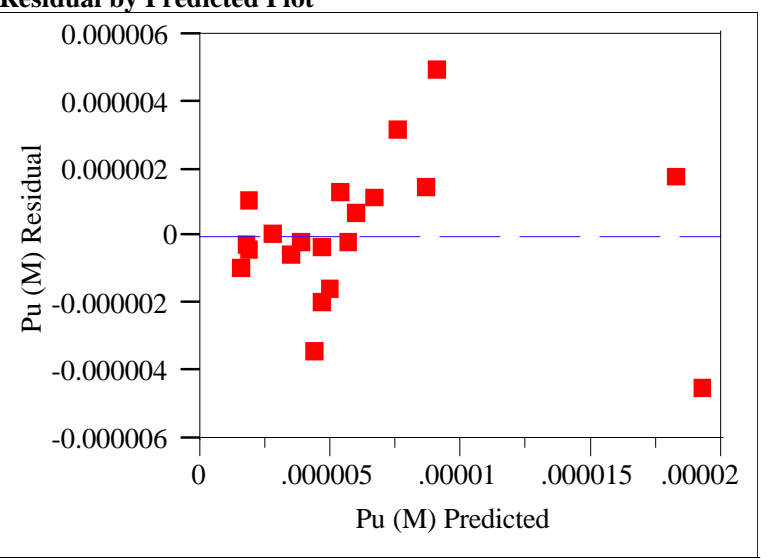

Response Sample 1Am (M)

Actual by Predicted Plot

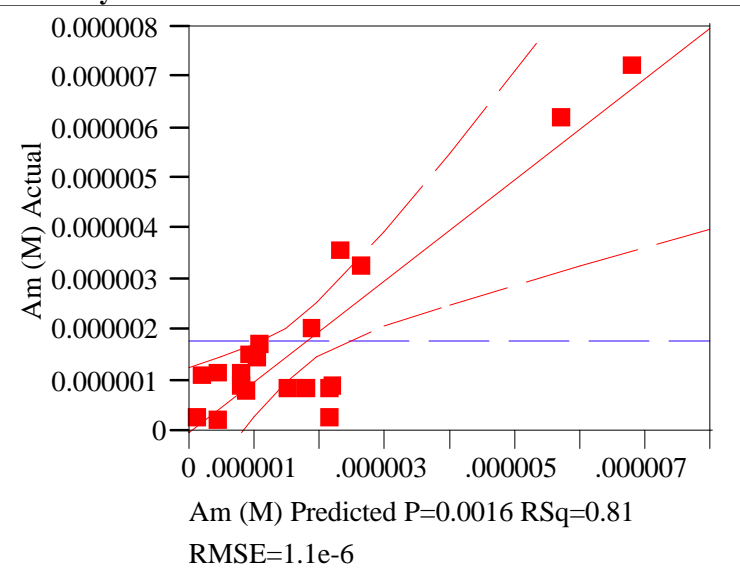

Summary of Fit

\begin{tabular}{|c|c|c|c|c|c|}
\hline \multicolumn{3}{|l|}{ RSquare } & \multicolumn{3}{|c|}{.807219} \\
\hline \multicolumn{3}{|c|}{ RSquare Adj } & \multicolumn{3}{|c|}{0.694764} \\
\hline \multicolumn{3}{|c|}{ Root Mean Square Error } & \multicolumn{3}{|c|}{0.000001} \\
\hline \multicolumn{3}{|c|}{ Mean of Response } & \multicolumn{3}{|c|}{0.000002} \\
\hline \multicolumn{3}{|c|}{ Observations (or Sum Wgts) } & \multicolumn{3}{|l|}{20} \\
\hline \multicolumn{6}{|c|}{ Analysis of Variance } \\
\hline Source & DF & Sum of Squares & Mean Square & \multicolumn{2}{|c|}{ F Ratio } \\
\hline Model & 7 & $5.5745 \mathrm{e}-11$ & $7.964 \mathrm{e}-12$ & \multicolumn{2}{|c|}{7.1781} \\
\hline Error & 12 & \multirow{2}{*}{$\begin{array}{l}1.3313 \mathrm{e}-11 \\
6.9058 \mathrm{e}-11\end{array}$} & \multirow[t]{2}{*}{$1.109 \mathrm{e}-12$} & \multicolumn{2}{|c|}{ Prob $>F$} \\
\hline C. Total & 19 & & & \multicolumn{2}{|c|}{0.0016} \\
\hline \multicolumn{6}{|c|}{ Parameter Estimates } \\
\hline \multicolumn{2}{|c|}{ Term } & Estimate & Std Error & t Ratio & Prob $>|t|$ \\
\hline \multicolumn{2}{|l|}{ Intercept } & $3.6472 \mathrm{e}-7$ & 0.000002 & 0.22 & 0.8260 \\
\hline \multicolumn{2}{|c|}{ Temp (oC) } & $-1.764 \mathrm{e}-8$ & $8.599 \mathrm{e}-9$ & -2.05 & 0.0627 \\
\hline \multicolumn{2}{|c|}{$\mathrm{OH}-(\mathrm{M})$} & $4.5572 \mathrm{e}-7$ & $1.077 \mathrm{e}-7$ & 4.23 & 0.0012 \\
\hline \multicolumn{2}{|c|}{$\mathrm{Al}(\mathrm{OH}) 4,-(\mathrm{M})$} & $2.0305 \mathrm{e}-7$ & 0.000001 & 0.20 & 0.8442 \\
\hline \multicolumn{2}{|c|}{$\mathrm{SO} 4,2-(\mathrm{M})$} & $9.5676 \mathrm{e}-7$ & 0.000003 & 0.37 & 0.7214 \\
\hline $\mathrm{CO} 3,2-(1$ & & 0.000001 & $8.144 \mathrm{e}-7$ & 1.26 & 0.2319 \\
\hline NO3,- (M & & $3.5722 \mathrm{e}-9$ & $2.382 \mathrm{e}-7$ & 0.01 & 0.9883 \\
\hline $\mathrm{NO} 2,-(\mathrm{M}$ & & $1.5456 \mathrm{e}-7$ & $1.972 \mathrm{e}-7$ & 0.78 & 0.4483 \\
\hline
\end{tabular}

Residual by Predicted Plot

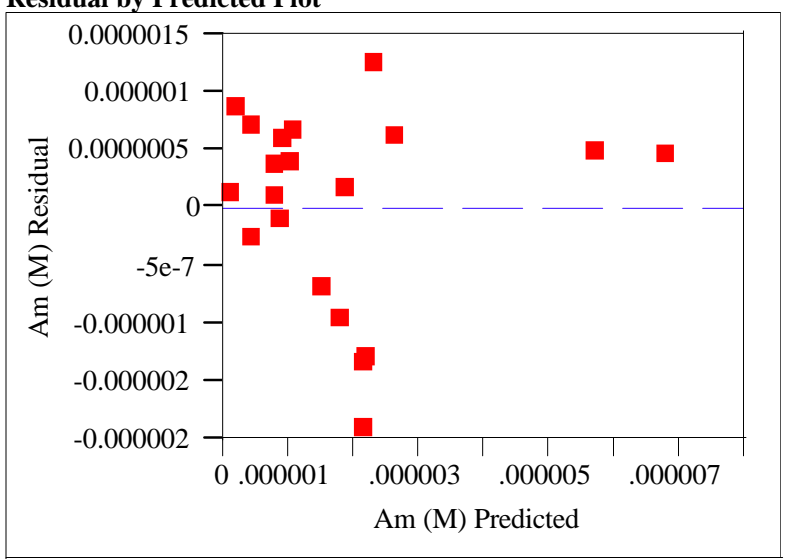


Exhibit D.3 First-Order Fits of the Am and Pu Solubility Data for Each Sample and the Average (continued)

Response Sample 2 Pu (M)

Actual by Predicted Plot

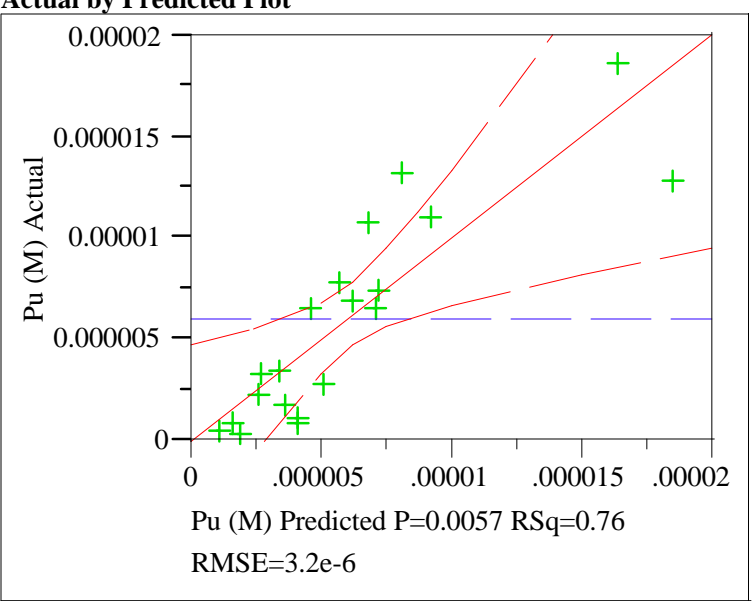

Summary of Fit

\begin{tabular}{|c|c|c|c|c|c|}
\hline \multicolumn{3}{|l|}{ RSquare } & \multicolumn{3}{|c|}{0.75719} \\
\hline \multicolumn{3}{|c|}{ RSquare Adj } & \multicolumn{3}{|c|}{0.615551} \\
\hline \multicolumn{3}{|c|}{ Root Mean Square Error } & \multicolumn{3}{|c|}{0.000003} \\
\hline \multicolumn{3}{|c|}{ Mean of Response } & \multicolumn{3}{|c|}{0.000006} \\
\hline \multicolumn{3}{|c|}{ Observations (or Sum Wgts) } & \multicolumn{3}{|l|}{20} \\
\hline \multicolumn{6}{|c|}{ Analysis of Variance } \\
\hline Source & $\mathrm{DF}$ & Sum of Squares & Mean Square & \multicolumn{2}{|c|}{ F Ratio } \\
\hline Model & 7 & $3.8821 \mathrm{e}-10$ & $5.546 \mathrm{e}-11$ & \multicolumn{2}{|c|}{5.3459} \\
\hline Error & 12 & $1.2449 \mathrm{e}-10$ & $1.037 \mathrm{e}-11$ & \multicolumn{2}{|c|}{ Prob $>$ F } \\
\hline C. Total & 19 & $5.127 \mathrm{e}-10$ & & \multicolumn{2}{|c|}{0.0057} \\
\hline \multicolumn{6}{|c|}{ Parameter Estimates } \\
\hline \multicolumn{3}{|c|}{ Term } & Std Error & t Ratio & $\operatorname{Prob}>|t|$ \\
\hline \multicolumn{2}{|l|}{ Intercept } & 0.0000014 & 0.000005 & 0.28 & 0.7867 \\
\hline \multicolumn{2}{|c|}{ Temp (oC) } & $-3.591 e-8$ & $2.629 \mathrm{e}-8$ & -1.37 & 0.1971 \\
\hline \multicolumn{2}{|c|}{$\mathrm{OH}-(\mathrm{M})$} & 0.0000012 & $3.293 \mathrm{e}-7$ & 3.64 & 0.0034 \\
\hline \multicolumn{2}{|c|}{$\mathrm{Al}(\mathrm{OH}) 4,-(\mathrm{M})$} & 0.0000012 & 0.000003 & 0.40 & 0.6993 \\
\hline \multicolumn{2}{|c|}{$\mathrm{SO} 4,2-(\mathrm{M})$} & $-7.226 \mathrm{e}-7$ & 0.000008 & -0.09 & 0.9296 \\
\hline \multicolumn{2}{|c|}{$\mathrm{CO} 3,2-(\mathrm{M})$} & 0.000005 & 0.000002 & 2.02 & 0.0664 \\
\hline \multicolumn{2}{|c|}{ NO3,- (M) } & $-1.785 \mathrm{e}-7$ & $7.284 \mathrm{e}-7$ & -0.24 & 0.8106 \\
\hline \multicolumn{2}{|c|}{ NO2,- (M) } & $3.3814 \mathrm{e}-7$ & $6.029 \mathrm{e}-7$ & 0.56 & 0.5852 \\
\hline
\end{tabular}

Residual by Predicted Plot

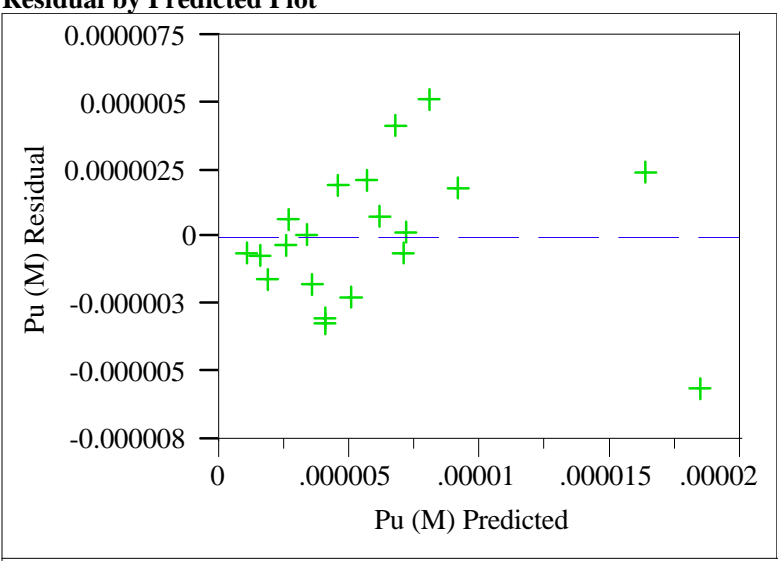

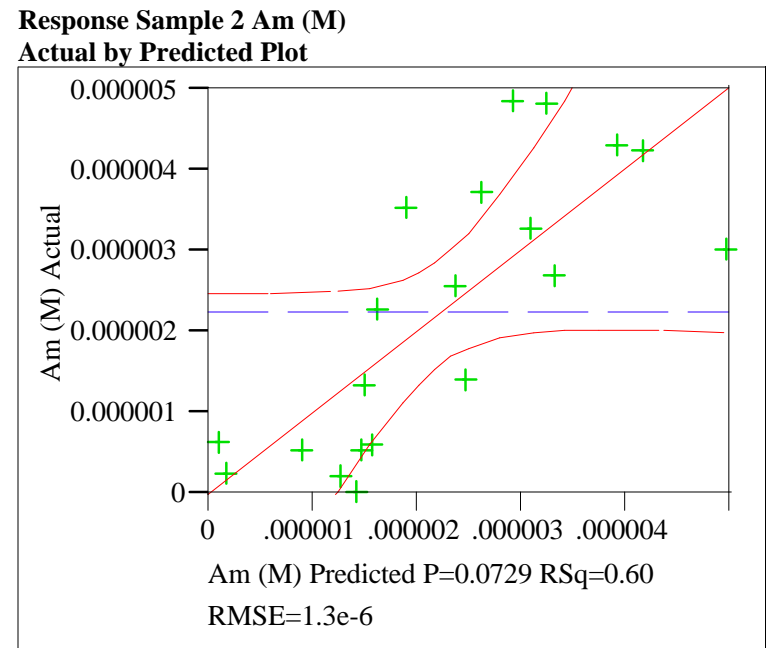

\section{Summary of Fit}

RSquare

RSquare Adj

0.599278

Root Mean Squa

Mean of Response

Observations (or Sum Wgts)

Analysis of Variance

Source DF Sum of Squares Mean Square F Ratio

Model $\quad 7 \quad 3.1976 \mathrm{e}-11 \quad 4.568 \mathrm{e}-12 \quad 2.5637$

Error $\quad 12 \quad 2.1382 \mathrm{e}-11 \quad 1.782 \mathrm{e}-12 \quad$ Prob $>$ F

$\begin{array}{lllr}\text { C. Total } 19 & 5.3358 \mathrm{e}-11 & 0.0729\end{array}$

Parameter Estimates

Term

Intercept

Temp (oC)

$\mathrm{OH}-(\mathrm{M})$

$\mathrm{Al}(\mathrm{OH}) 4,-(\mathrm{M})$

SO4, 2- (M)

CO3,2- (M)

$\mathrm{NO} 3,-(\mathrm{M})$

NO2,- (M)

0.365523

0.000001
0.000002

$$
20
$$

Residual by Predicted Plo

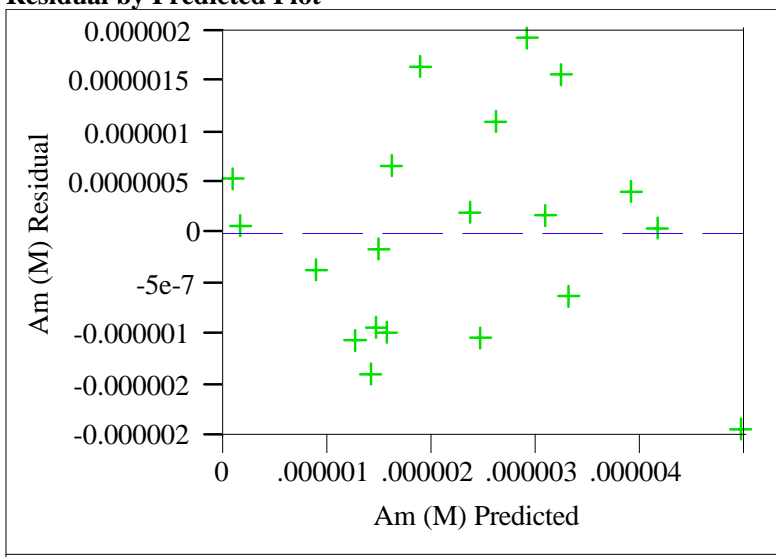


Exhibit D.3 First-Order Fits of the Am and Pu Solubility Data for Each Sample and the Average (continued)

Response Sample 3 Pu (M)

Actual by Predicted Plot

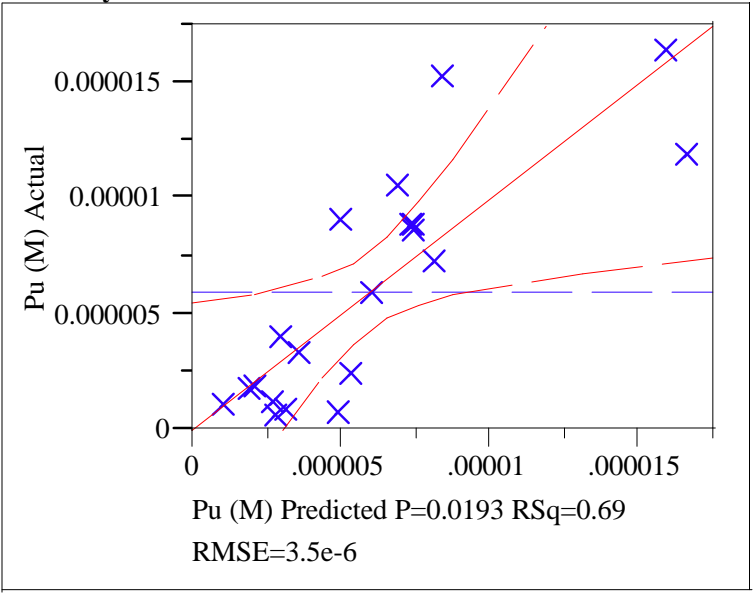

Summary of Fit

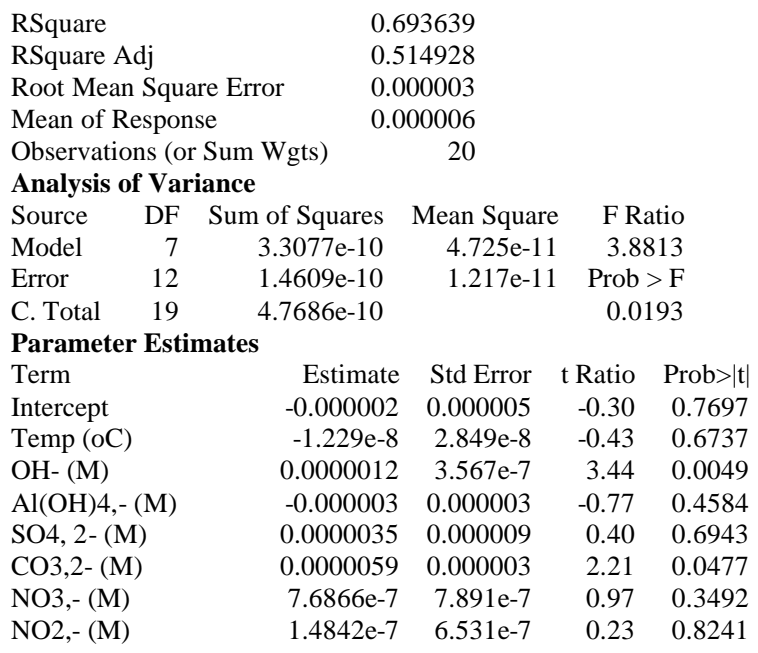

Residual by Predicted Plot

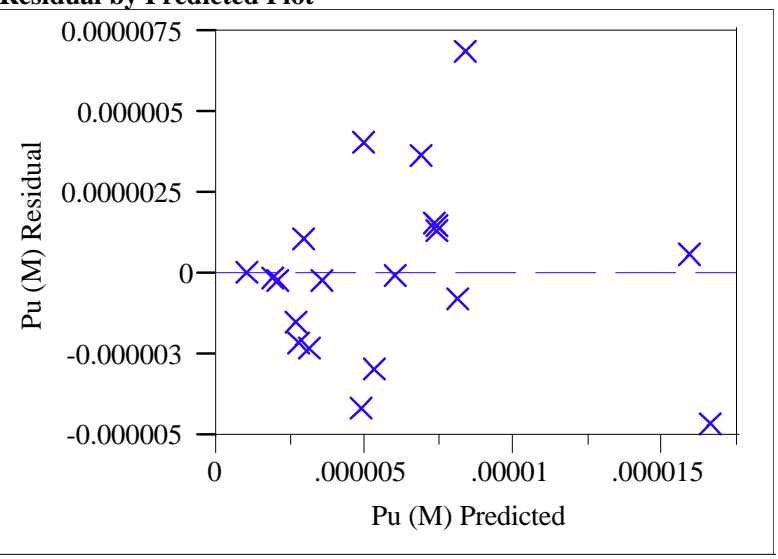

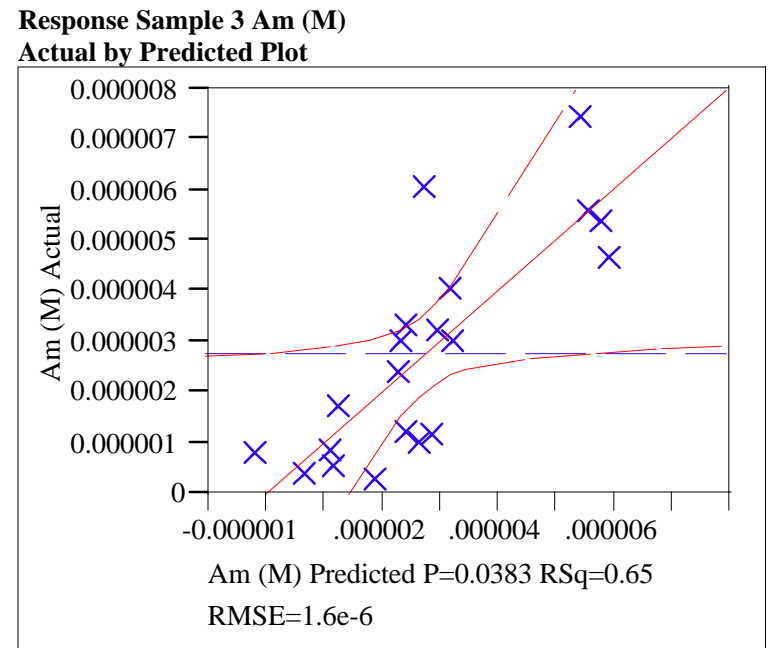

\section{Summary of Fit}

RSquare

RSquare Adj

0.649203

Root Mean S

Mean of Response

Observations (or Sum Wgts)

Analysis of Variance

Source DF Sum of Squares Mean Square F Ratio

$\begin{array}{lllll}\text { Model } & 7 & 5.6901 \mathrm{e}-11 & 8.129 \mathrm{e}-12 & 3.1725\end{array}$

$\begin{array}{lllll}\text { Error } & 12 & 3.0747 \mathrm{e}-11 & 2.562 \mathrm{e}-12 & \text { Prob }>\text { F }\end{array}$

$\begin{array}{llll}\text { C. Total } 19 & 8.7648 \mathrm{e}-11 & 0.0383\end{array}$

Parameter Estimates

Term

Intercept

Temp (oC)

$\mathrm{OH}-(\mathrm{M})$

$\mathrm{Al}(\mathrm{OH}) 4,-(\mathrm{M})$

$\mathrm{SO} 4,2-(\mathrm{M})$

$\mathrm{CO} 3,2-(\mathrm{M})$

$\mathrm{NO} 3,-(\mathrm{M})$

$\mathrm{NO} 2,-(\mathrm{M})$

Residual by Predicted Plo
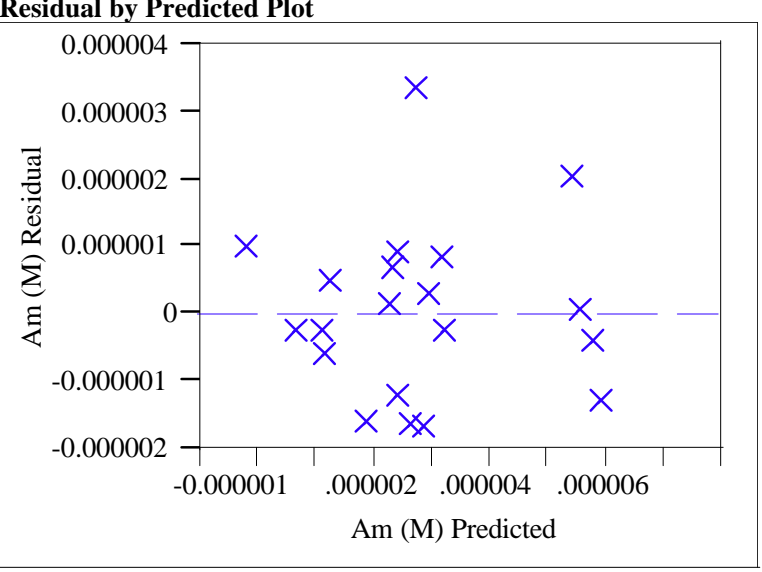
Exhibit D.3 First-Order Fits of the Am and Pu Solubility Data for Each Sample and the Average (continued)

Response Average Pu (M)

Actual by Predicted Plot

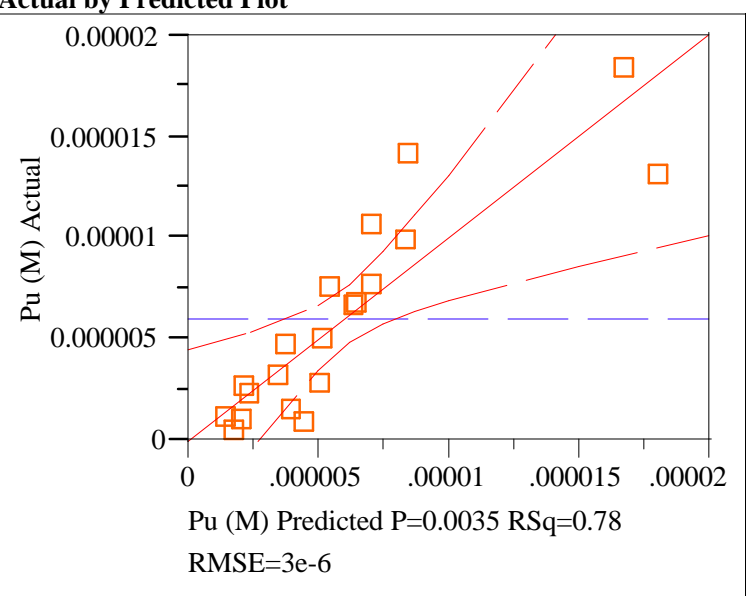

Summary of Fit

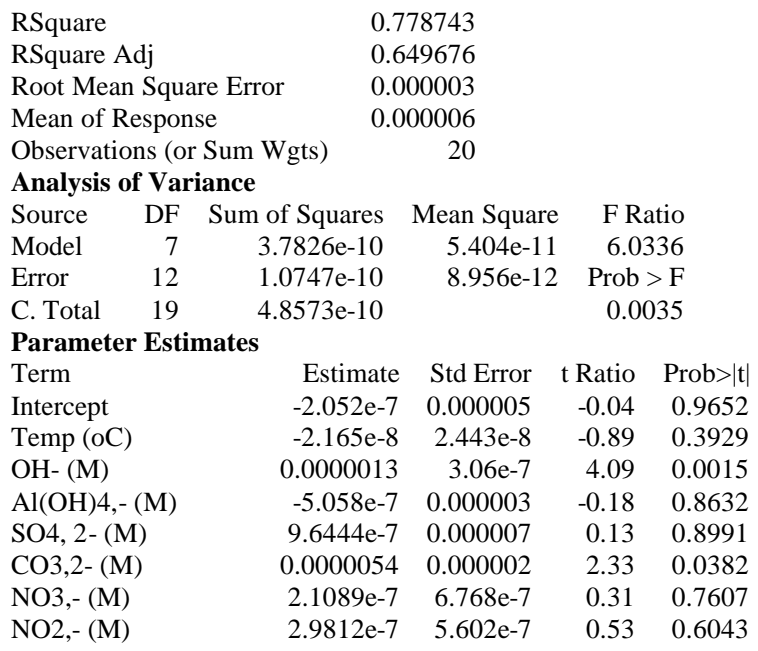

Residual by Predicted Plot

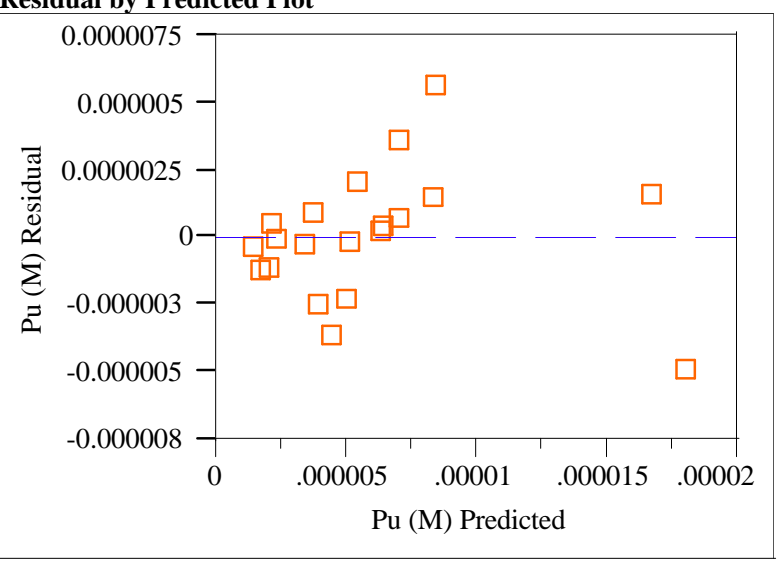

Response Average Am (M)

Actual by Predicted Plot

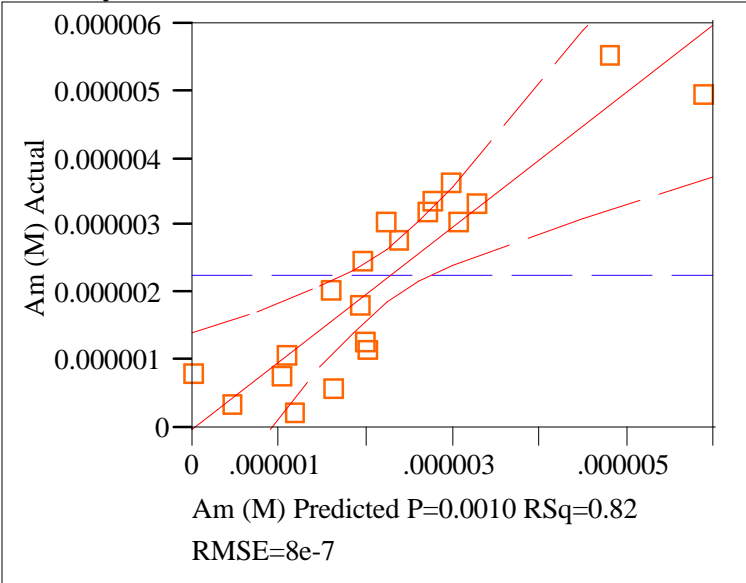

Summary of Fit

RSquare

0.824889

RSquare Adj

0.722741

Root Mean Square Error

7.964e-7

Mean of Response

Observations (or Sum Wgts)

Analysis of Variance

Source DF Sum of Squares Mean Square F Ratio

$\begin{array}{lllll}\text { Model } & 7 & 3.5856 \mathrm{e}-11 & 5.122 \mathrm{e}-12 & 8.0754\end{array}$

Error $\quad 12 \quad 7.6116 \mathrm{e}-12 \quad 6.343 \mathrm{e}-13 \quad$ Prob $>$ F

$\begin{array}{llll}\text { C. Total } 19 & 4.3467 \mathrm{e}-11 & 0.0010\end{array}$

Parameter Estimates

Term

Intercept

Temp (oC)

$\mathrm{OH}-(\mathrm{M})$

$\mathrm{Al}(\mathrm{OH}) 4,-(\mathrm{M})$

$\mathrm{SO} 4,2-(\mathrm{M})$

$\mathrm{CO} 3,2-(\mathrm{M})$

$\mathrm{NO} 3,-(\mathrm{M})$

NO2,- (M)

$\begin{array}{llll}1.0334 \mathrm{e}-7 & 1.491 \mathrm{e}-7 & 0.69 & 0.5014\end{array}$

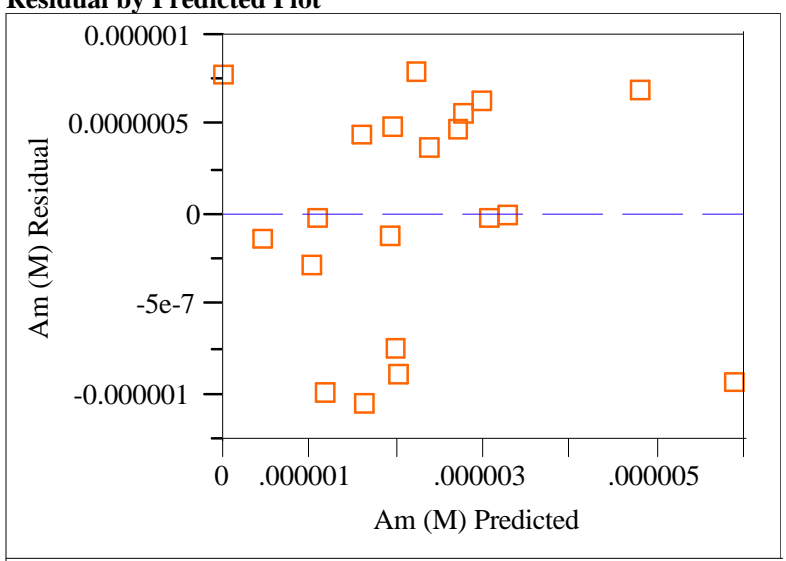


WSRC-TR-2004-00349

Revision 0

Exhibit D.4 Final First-Order Fit of the Am Solubility Data Using the Sample Averages

Response Average Am (M)

Actual by Predicted Plot

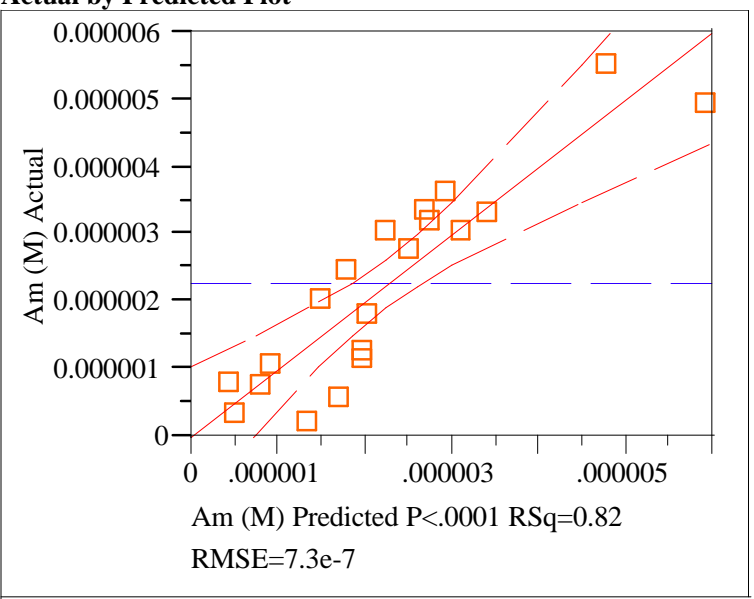

Summary of Fit

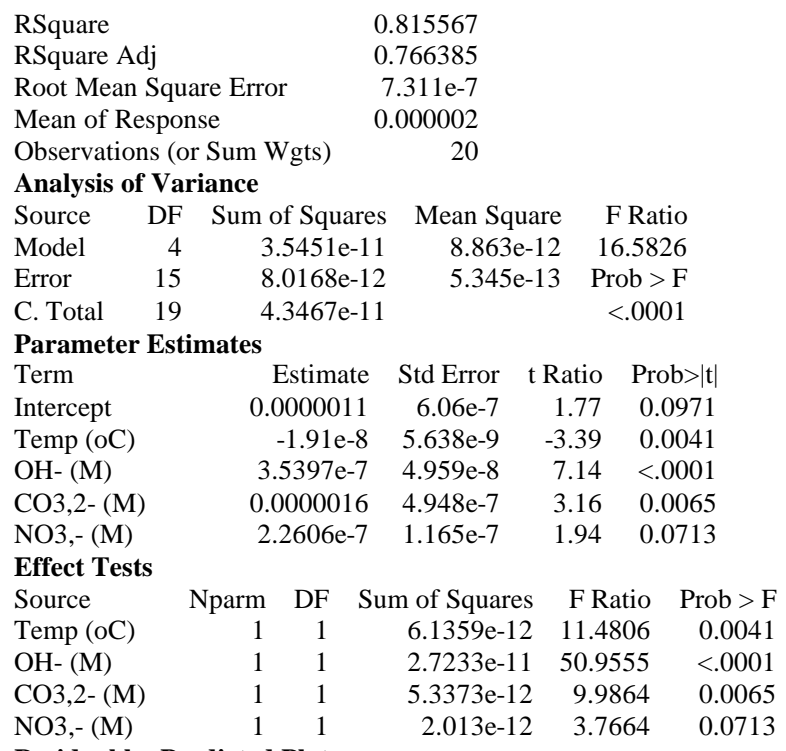

Residual by Predicted Plot

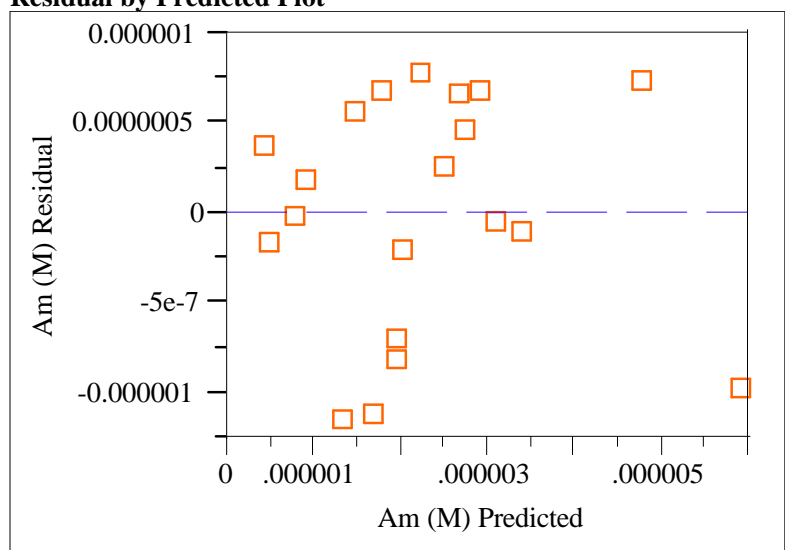


WSRC-TR-2004-00349

Revision 0

Exhibit D.5 Final First-Order Fit of the Pu Solubility Data Using the Sample Averages

Response Pu (M)

Whole Model

Actual by Predicted Plot

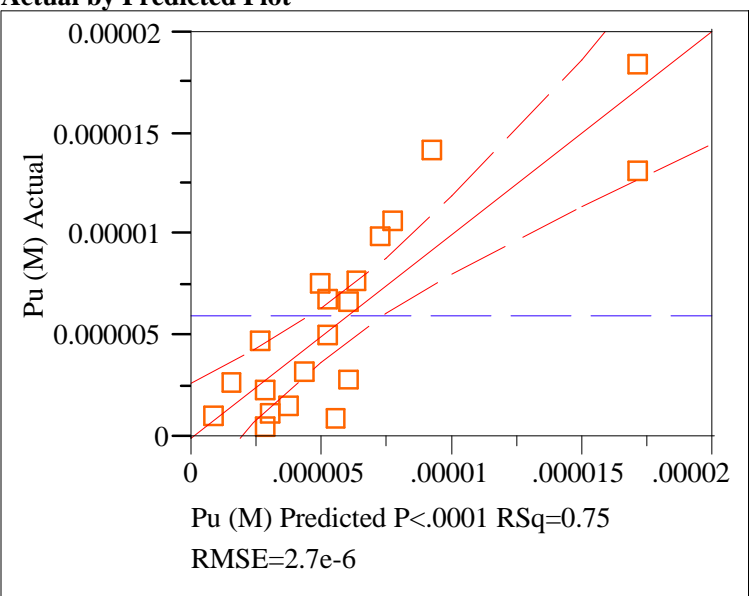

Summary of Fit

RSquare

0.74651

RSquare Adj

0.716688

Root Mean Square Error

0.000003

Mean of Response

Observations (or Sum Wgts)

Analysis of Variance

Source DF Sum of Squares Mean Square F Ratio

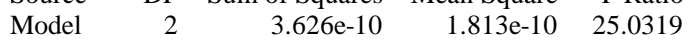

$\begin{array}{lllll}\text { Error } & 17 & 1.2313 \mathrm{e}-10 & 7.243 \mathrm{e}-12 & \text { Prob }>\mathrm{F}\end{array}$

$\begin{array}{llll}\text { C. Total } 19 & 4.8573 \mathrm{e}-10 & <.0001\end{array}$

Lack Of Fit

Source DF Sum of Squares Mean Square F Ratio

$\begin{array}{llll}\text { Lack Of Fit } \quad 15 & 1.0224 \mathrm{e}-10 & 6.816 \mathrm{e}-12 & 0.6527\end{array}$

$\begin{array}{llll}\text { Pure Error } 2.0887 \mathrm{e}-11 & 2 & 1.044 \mathrm{e}-11 \quad \text { Prob }>\text { F }\end{array}$

Total Error $17 \quad 1.2313 \mathrm{e}-10 \quad 0.7520$

$\operatorname{Max} \mathrm{RSq}$

0.9570

Parameter Estimates

Term Estimate Std Error t Ratio Prob $>|t|$

$\begin{array}{lllll}\text { Intercept } & -7.479 \mathrm{e}-8 & 0.000001 & -0.06 & 0.9550\end{array}$

$\begin{array}{lllll}\mathrm{OH}-(\mathrm{M}) & 0.0000012 & 1.629 \mathrm{e}-7 & 7.06 & <.0001\end{array}$

$\begin{array}{lllll}\mathrm{CO} 3,2-(\mathrm{M}) & 0.0000049 & 0.000002 & 2.70 & 0.0152\end{array}$

Effect Tests

Source Nparm DF Sum of Squares F Ratio Prob $>$ F

$\begin{array}{lrrrrr}\text { OH- (M) } & 1 & 1 & 3.6109 \mathrm{e}-10 & 49.8555 & <.0001\end{array}$

$\begin{array}{llllll}\mathrm{CO} 3,2-(\mathrm{M}) & 1 & 1 & 5.2766 \mathrm{e}-11 & 7.2853 & 0.0152\end{array}$

Residual by Predicted Plot

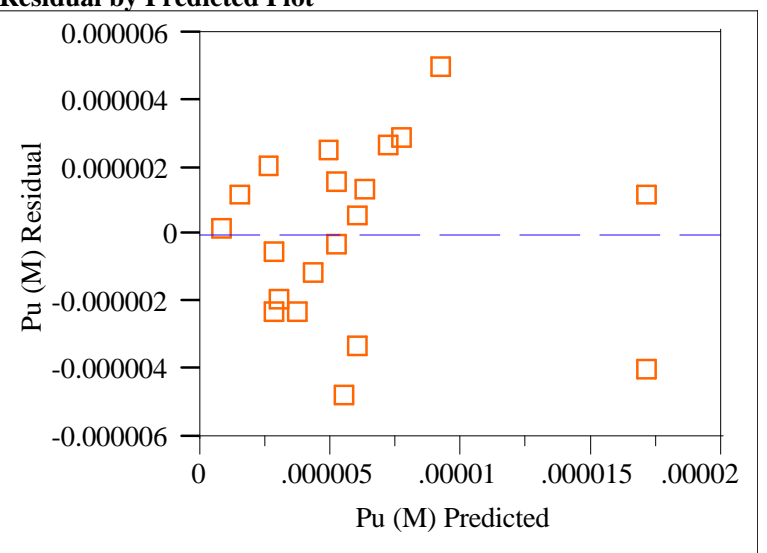


WSRC-TR-2004-00349

Revision 0

Exhibit D.6 Historical and Current Pu Solubility Data Versus the Factors of Interest
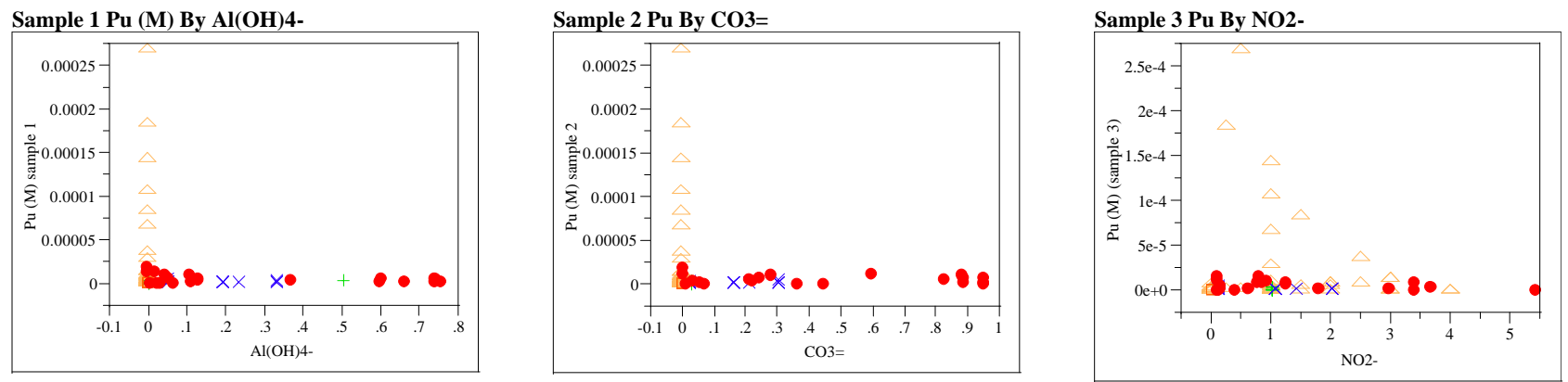

Sample 2 Pu (M) By Al(OH)4-
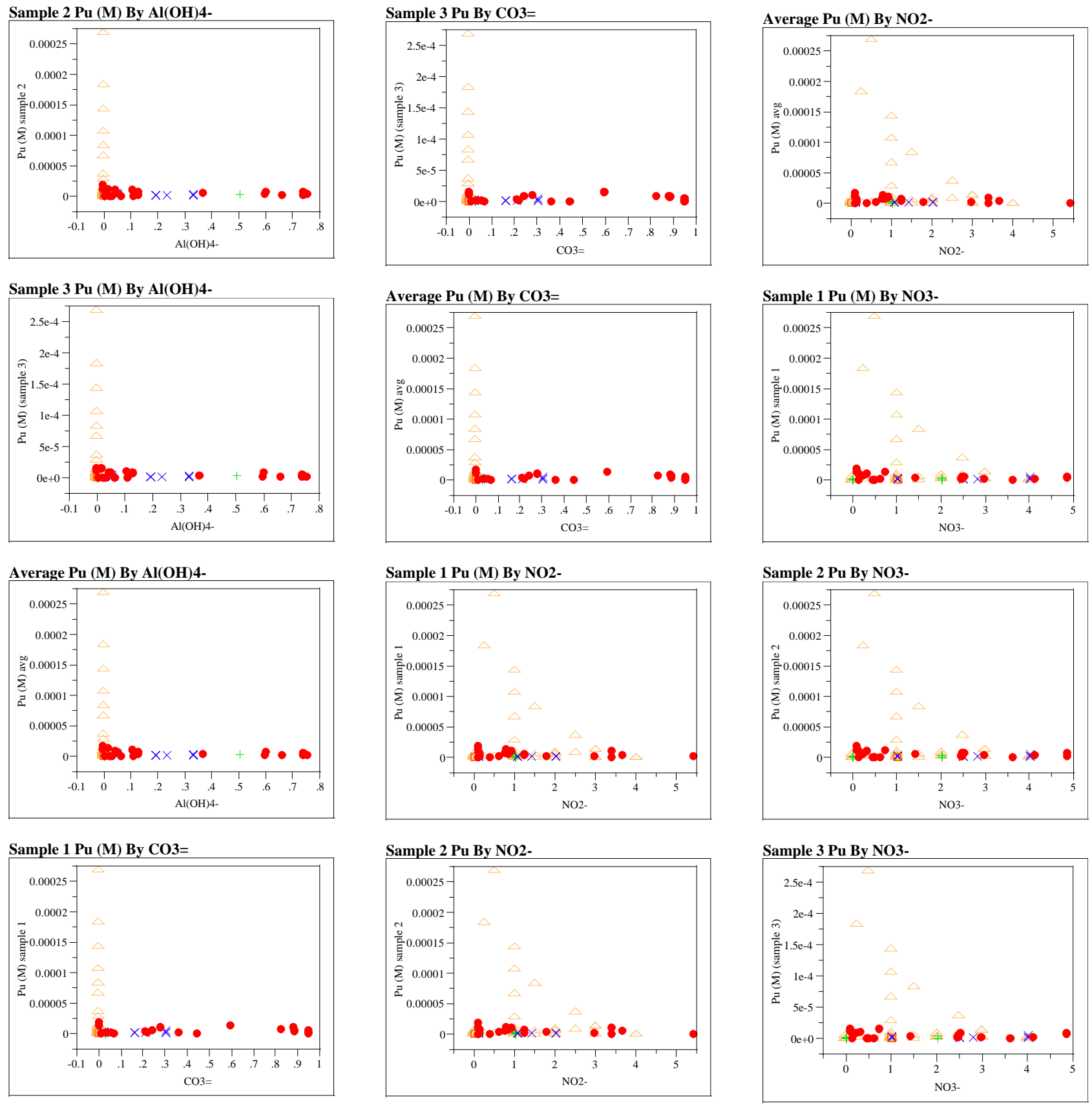
WSRC-TR-2004-00349

Revision 0

Exhibit D.6 Historical and Current Pu Solubility Data Versus the Factors of Interest continued

Average Pu (M) By NO3-

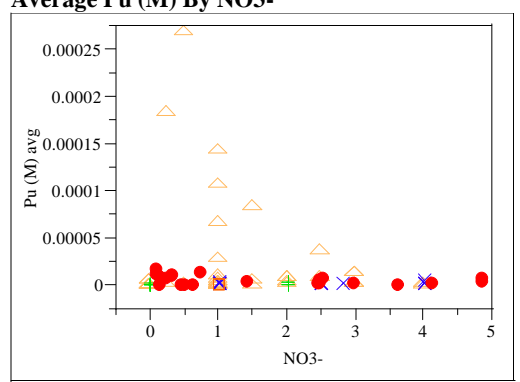

Sample 1 Pu (M) By SO4=

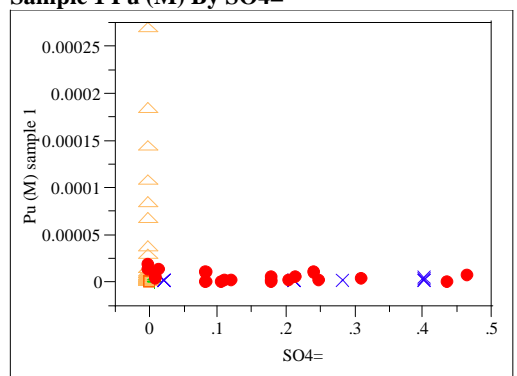

Sample 2 Pu By SO4=

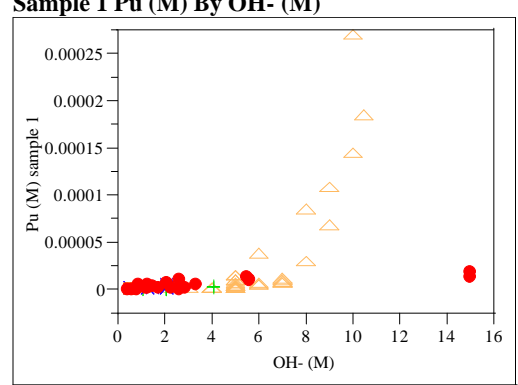

Sample 2 Pu By OH- (M)

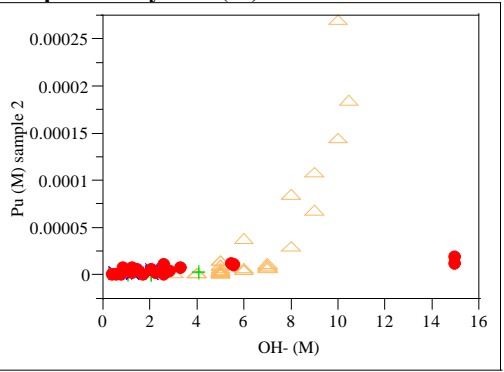

Sample 3 Pu By OH- (M)

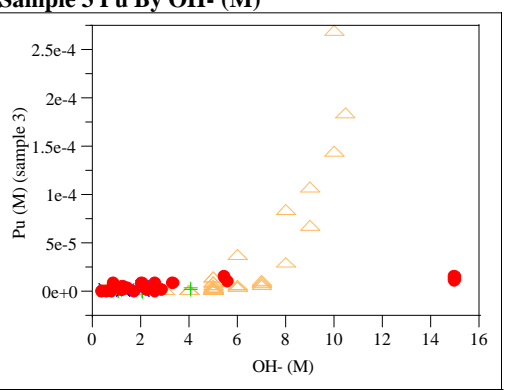

Average Pu (M) By OH- (M)

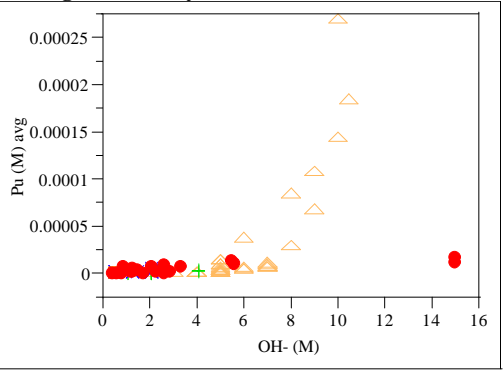

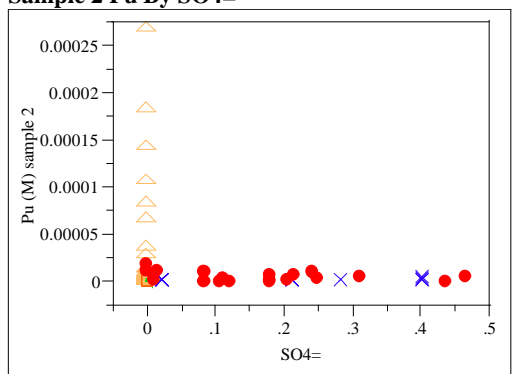

Sample 3 Pu By SO4=

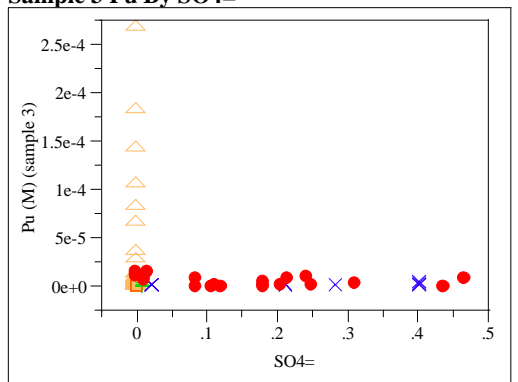

Average Pu (M) By SO4=

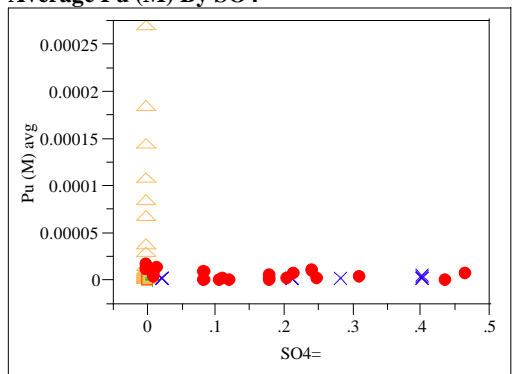

Sample 1 Pu (M) By Temperature

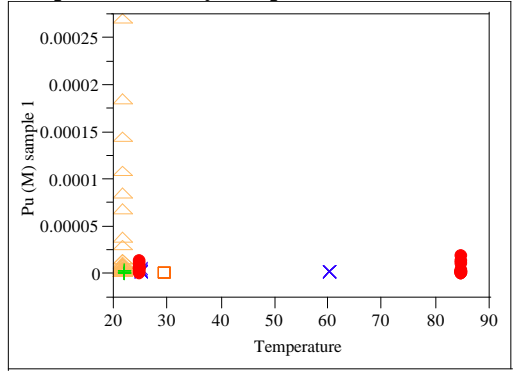

Sample 2 Pu By Temperature

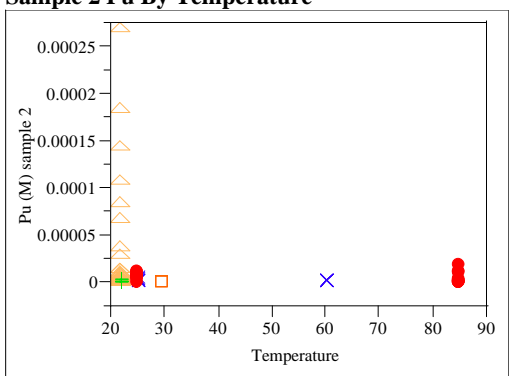

Sample 3 Pu By Temperature
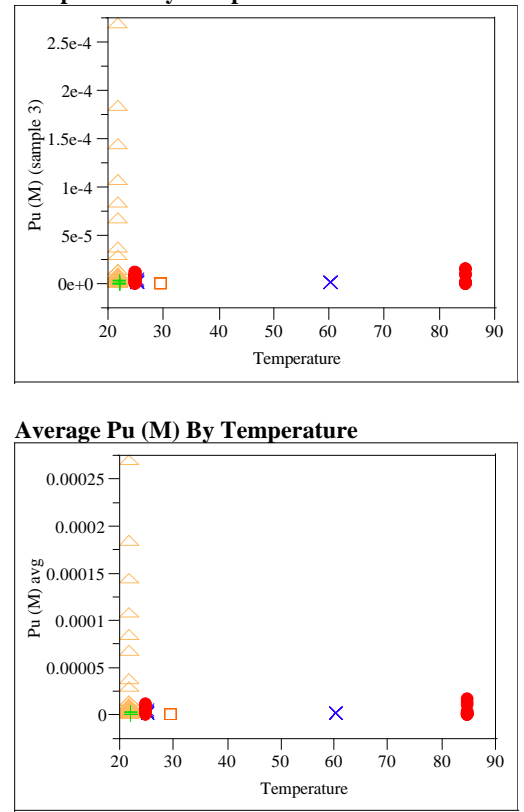

\section{Legend for Plots}

\begin{tabular}{|c|c|c|c|}
\hline & & Data Set & $\begin{array}{c}\text { Number of Data } \\
\text { Points }\end{array}$ \\
\hline$\triangle$ & 1 & 1 & 42 \\
\hline+ & 2 & 2 & 10 \\
\hline $\mathbf{x}$ & 3 & 3 & 14 \\
\hline 口 & 4 & 4 & 5 \\
\hline$\bullet$ & 5 & IRD Study & 20 \\
\hline
\end{tabular}


WSRC-TR-2004-00349

Revision 0

\section{Exhibit D.7 Modified Response Surface Model Fit to Historical and Current Pu Data}

Response Sample 1 Pu (M)

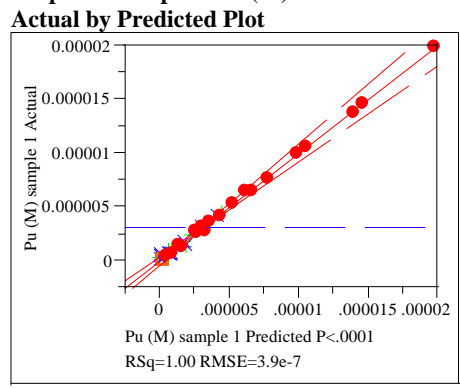

Summary of Fit

RSquare

0.997522

RSquare Adj

0.991504

$3.937 \mathrm{e}-7$

0.000003

Mean of Response

49

Analysis of Variance

$\begin{array}{lrrrr}\text { Source } & \text { DF } & \text { Sum of Squares } & \text { Mean Square } & \text { F Ratio } \\ \text { Model } & 34 & 8.7337 \mathrm{e}-10 & 2.569 \mathrm{e}-11 & 165.7560 \\ \text { Error } & 14 & 2.1696 \mathrm{e}-12 & 1.55 \mathrm{e}-13 & \text { Prob }>\text { F } \\ \text { C. Total } & 48 & 8.7554 \mathrm{e}-10 & & <.0001\end{array}$

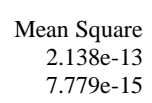

F Ratio

Source

Lack Of Fit

DF Sum of Squares

$2.1385 \mathrm{e}-12$

$3.1117 \mathrm{e}-14$

Total Error

14

$2.1696 \mathrm{e}-12$

27.4897

Prob > F

0.0030
Max RSq

1.0000

Parameter Estimates

Term

Intercept

$\mathrm{Al}(\mathrm{OH}) 4-$

$\mathrm{CO} 3=$

$\mathrm{NO} 2$

NO3-

$\mathrm{OH}-(\mathrm{M})$

$\mathrm{SO} 4=$

Temperature

$\mathrm{CO} 3=* \mathrm{Al}(\mathrm{OH}) 4$

$\mathrm{NO} 2-* \mathrm{Al}(\mathrm{OH}) 4$

$\mathrm{NO} 3-* \mathrm{Al}(\mathrm{OH}) 4$

$\mathrm{OH}-(\mathrm{M}) * \mathrm{Al}(\mathrm{OH}) 4-$

$\mathrm{SO} 4=* \mathrm{Al}(\mathrm{OH}) 4$

Temperature* $\mathrm{Al}(\mathrm{OH}) 4$

$\mathrm{NO} 2-* \mathrm{CO} 3=$

$\mathrm{NO} 3-* \mathrm{CO} 3=$

$\mathrm{OH}-(\mathrm{M}) * \mathrm{CO} 3=$

$\mathrm{SO} 4=* \mathrm{CO} 3=$

Temperature $* \mathrm{CO} 3=$

NO3-*NO2-

$\mathrm{OH}-(\mathrm{M}) * \mathrm{NO} 2-$

$\mathrm{SO} 4=* \mathrm{NO} 2$

Temperature*NO2-

$\mathrm{OH}-(\mathrm{M}) * \mathrm{NO} 3-$

$\mathrm{SO} 4=* \mathrm{NO} 3$

Temperature*NO3-

$\mathrm{SO} 4=* \mathrm{OH}-(\mathrm{M})$

Temperature* ${ }^{*} \mathrm{OH}-(\mathrm{M})$

Temperature*SO4=

$\mathrm{Al}(\mathrm{OH}) 4-* \mathrm{Al}(\mathrm{OH}) 4$

$\mathrm{CO} 3=* \mathrm{CO} 3=$

$\mathrm{NO} 2-* \mathrm{NO} 2-$

$\mathrm{OH}-(\mathrm{M}) * \mathrm{OH}-(\mathrm{M})$

$\mathrm{SO} 4=* \mathrm{SO} 4=$

NO3-*NO3-

$\begin{array}{rrrr}\text { Estimate } & \text { Std Error } & \mathrm{t} \text { Ratio } & \text { Prob }>|\mathrm{t}| \\ 0.0000011 & 9.89 \mathrm{e}-7 & 1.15 & 0.2693 \\ 0.0000078 & 0.000004 & 1.99 & 0.0665 \\ -0.000014 & 0.000002 & -6.11 & <.0001 \\ -8.822 \mathrm{e}-7 & 6.505 \mathrm{e}-7 & -1.36 & 0.1965 \\ -6.875 \mathrm{e}-7 & 5.34 \mathrm{e}-7 & -1.29 & 0.2188 \\ 2.9373 \mathrm{e}-7 & 9.607 \mathrm{e}-7 & 0.31 & 0.7643 \\ 0.0000011 & 0.000008 & 0.14 & 0.8924 \\ -3.429 \mathrm{e}-8 & 4.538 \mathrm{e}-8 & -0.76 & 0.4624 \\ -0.000003 & 0.000004 & -0.79 & 0.4419 \\ 3.7219 \mathrm{e}-7 & 0.000002 & 0.24 & 0.8109 \\ -0.000004 & 0.000001 & -3.51 & 0.0035 \\ -0.000002 & 7.821 \mathrm{e}-7 & -2.26 & 0.0401 \\ 0.0000055 & 0.000008 & 0.65 & 0.5232 \\ -1.036 \mathrm{e}-7 & 1.56 \mathrm{e}-8 & -6.64 & <.0001 \\ 0.0000021 & 0.000002 & 1.40 & 0.1833 \\ 5.8435 \mathrm{e}-7 & 7.248 \mathrm{e}-7 & 0.81 & 0.4336 \\ 0.0000036 & 3.71 \mathrm{e}-7 & 9.74 & <.0001 \\ 0.0000124 & 0.000006 & 2.23 & 0.0424 \\ 2.8242 \mathrm{e}-8 & 2.19 \mathrm{e}-8 & 1.29 & 0.2181 \\ 1.6237 \mathrm{e}-7 & 1.269 \mathrm{e}-7 & 1.28 & 0.2214 \\ 4.3513 \mathrm{e}-8 & 7.235 \mathrm{e}-7 & 0.06 & 0.9529 \\ 0.000001 & 0.000002 & 0.54 & 0.5982 \\ 3.3772 \mathrm{e}-9 & 1.184 \mathrm{e}-8 & 0.29 & 0.7796 \\ 2.6833 \mathrm{e}-7 & 9.912 \mathrm{e}-8 & 2.71 & 0.0170 \\ -0.000001 & 8.406 \mathrm{e}-7 & -1.59 & 0.1344 \\ -9.38 \mathrm{e}-10 & 4.792 \mathrm{e}-9 & -0.20 & 0.8477 \\ 7.1202 \mathrm{e}-7 & 8.321 \mathrm{e}-7 & 0.86 & 0.4066 \\ 7.9972 \mathrm{e}-9 & 3.002 \mathrm{e}-9 & 2.66 & 0.0185 \\ 8.7072 \mathrm{e}-8 & 8.101 \mathrm{e}-8 & 1.07 & 0.3006 \\ 0.0000168 & 0.000005 & 3.29 & 0.0053 \\ 0.0000077 & 0.000002 & 4.27 & 0.0008 \\ -7.286 \mathrm{e}-9 & 1.002 \mathrm{e}-7 & -0.07 & 0.9431 \\ 2.9692 \mathrm{e}-8 & 6.183 \mathrm{e}-8 & 0.48 & 0.6385 \\ -0.00001 & 0.000013 & -0.79 & 0.4447 \\ 2.9828 \mathrm{e}-7 & 1.434 \mathrm{e}-7 & 2.08 & 0.0564\end{array}$

Response Sample 2 Pu (M)

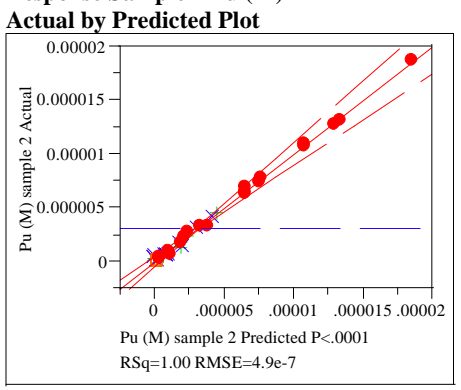

Summary of Fit

$\begin{array}{lr}\text { RSquare } & 0.995948 \\ \text { RSquare Adj } & 0.986109 \\ \text { Root Mean Square Error } & 4.94 \mathrm{e}-7 \\ \text { Mean of Response } & 0.000003 \\ \text { Observations (or Sum Wgts) } & 49\end{array}$

Analysis of Variance

$\begin{array}{lrrrr}\text { Source } & \text { DF } & \text { Sum of Squares } & \text { Mean Square } & \text { F Ratio } \\ \text { Model } & 34 & 8.3972 \mathrm{e}-10 & 2.47 \mathrm{e}-11 & 101.2204 \\ \text { Error } & 14 & 3.416 \mathrm{e}-12 & 2.44 \mathrm{e}-13 & \text { Prob }>\text { F } \\ \text { C. Total } & 48 & 8.4314 \mathrm{e}-10 & & <.0001\end{array}$

Lack Of Fit

DF Sum of Squares

$3.3849 \mathrm{e}-12$

$3.1117 \mathrm{e}-14$

$3.416 \mathrm{e}-12$

Mean Square

$3.385 \mathrm{e}-13$

$7.779 \mathrm{e}-15$

F Ratio

Total Error

14

.

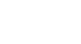

0.0012

Max RSq

1.0000

Parameter Estimates

Term

Intercept

$\mathrm{Al}(\mathrm{OH}) 4$ -

$\mathrm{CO} 3=$

$\mathrm{NO} 2-$

NO3-

OH- (M)

$\mathrm{SO} 4=$

Temperature

$\mathrm{CO} 3=* \mathrm{Al}(\mathrm{OH}) 4-$

$\mathrm{NO} 2-* \mathrm{Al}(\mathrm{OH}) 4-$

$\mathrm{NO} 3-* \mathrm{Al}(\mathrm{OH}) 4-$

$\mathrm{OH}-(\mathrm{M}) * \mathrm{Al}(\mathrm{OH}) 4-$

$\mathrm{SO} 4=* \mathrm{Al}(\mathrm{OH}) 4-$

Temperature* $\mathrm{Al}(\mathrm{OH}) 4$ -

$\mathrm{NO} 2-* \mathrm{CO} 3=$

NO3- $* \mathrm{CO} 3=$

$\mathrm{OH}-(\mathrm{M}) * \mathrm{CO} 3=$

$\mathrm{SO} 4=* \mathrm{CO} 3=$

Temperature $* \mathrm{CO} 3=$

NO3-*NO2-

$\mathrm{OH}-(\mathrm{M}) * \mathrm{NO} 2-$

$\mathrm{SO} 4=* \mathrm{NO} 2-$

Temperature*NO2-

$\mathrm{OH}-(\mathrm{M}) * \mathrm{NO} 3$

$\mathrm{SO} 4=* \mathrm{NO} 3-$

Temperature*NO3-

$\mathrm{SO} 4=* \mathrm{OH}-(\mathrm{M})$

Temperature* $\mathrm{OH}-(\mathrm{M})$

Temperature $* \mathrm{SO} 4=$

$\mathrm{Al}(\mathrm{OH}) 4-* \mathrm{Al}(\mathrm{OH}) 4$

$\mathrm{CO} 3=* \mathrm{CO} 3=$

NO2-*NO2-

$\mathrm{OH}-(\mathrm{M}) * \mathrm{OH}-(\mathrm{M})$

$\mathrm{SO} 4=* \mathrm{SO} 4=$

Estimate $6.0724 \mathrm{e}-7$

0.0000188

$-0.000009$

$-7.482 \mathrm{e}-7$

$-7.343 \mathrm{e}-7$

$-6.568 \mathrm{e}-7$

$-0.000016$

$8.4627 \mathrm{e}-9$

$-0.00001$

$-0.000002$

$-0.000007$

$-0.000004$

0.0000424

$-1.142 \mathrm{e}-7$

0.0000014

$3.1932 \mathrm{e}-7$

0.0000035

0.0000192

7.3196e-9

$-1.408 \mathrm{e}-7$

$8.0314 \mathrm{e}-7$

0.0000057

$-5.615 \mathrm{e}-9$

$2.3209 \mathrm{e}-7$

$-0.000001$

$-1.951 \mathrm{e}-8$

$5.4853 \mathrm{e}-7$

$5.8729 \mathrm{e}-9$

$1.3876 \mathrm{e}-7$

0.0000209

0.0000032

$-1.85 \mathrm{e}-7$

$8.204 \mathrm{e}-8$

$-0.000003$

Std Error

0.49

$0.000005 \quad 3.83$

$-0.000003 \quad-3.06$

$8.163 \mathrm{e}-7 \quad-0.92$

$6.7 \mathrm{e}-7 \quad-1.10$

$0.000001 \quad-0.54$

$0.00001-1.68$

$5.695 \mathrm{e}-8 \quad 0.15$

$0.000005 \quad-1.96$

$0.000002 \quad-1.00$

$0.000001-5.14$

$9.813 \mathrm{e}-7 \quad-3.82$

$0.000011 \quad 4.01$

$1.957 \mathrm{e}-8 \quad-5.83$

$0.000002 \quad 0.74$

$\begin{array}{ll}9.095 \mathrm{e}-7 & 0.35\end{array}$

4.655e-7 7.56

$0.000007 \quad 2.75$

$\begin{array}{ll}2.748 \mathrm{e}-8 & 0.27\end{array}$

$1.592 \mathrm{e}-7 \quad-0.88$

$9.079 \mathrm{e}-7 \quad 0.88$

$0.000002 \quad 2.36$

$\begin{array}{ll}1.485 \mathrm{e}-8 & -0.38\end{array}$

$1.244 \mathrm{e}-7 \quad 1.87$

$0.000001 \quad-1.11$

$6.013 \mathrm{e}-9 \quad-3.24$

$0.000001 \quad 0.53$

$3.767 \mathrm{e}-9 \quad 1.56$

$1.016 \mathrm{e}-7 \quad 1.37$

$0.000006 \quad 3.26$

$0.000002 \quad 1.41$

$\begin{array}{ll}1.258 \mathrm{e}-7 & -1.47\end{array}$

7.758e-8 $\quad 1.06$

$0.000016 \quad-0.18$

$1.8 \mathrm{e}-7 \quad 4.03$ 
WSRC-TR-2004-00349

Revision 0

Exhibit D.7 Modified Response Surface Model Fit to Historical and Current Pu Data

(Continued)

Response Sample 3 Pu (M)

Actual by Predicted Plot

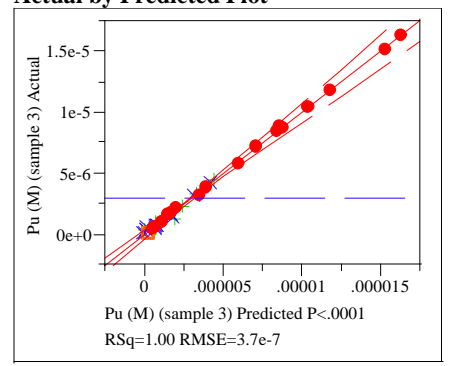

Summary of Fit

RSquare

RSquare Adj

Root Mean Square Erro

Mean of Response

Observations (or Sum Wgts)

0.997675

0.992028

$3.66 \mathrm{e}-7$

0.000003

49

Analysis of Variance

Source DF Sum of Squares

Model 34

Error

14

$8.0445 \mathrm{e}-10$

Mean Square

2.366e-11

$1.339 \mathrm{e}-13$

F Ratio

176.6729

C. Total

48

$8.0633 \mathrm{e}-10$

$<.0001$

Lack Of Fit

Source

Lack Of Fit

Pure Error

$\begin{array}{rr}\text { DF } & \text { Sum of Squares } \\ 10 & 1.8438 \mathrm{e}-12 \\ 4 & 3.1117 \mathrm{e}-14\end{array}$

Mean Square $1.844 \mathrm{e}-13$

$7.779 \mathrm{e}-15$

F Ratio

23.7017

Prob $>$ F

Parameter Estimates

Term

Intercept

$\mathrm{Al}(\mathrm{OH}) 4-$

$\mathrm{CO} 3=$

$\mathrm{NO} 2$

NO3-

$\mathrm{OH}-(\mathrm{M})$

$\mathrm{SO} 4=$

Temperature

$\mathrm{CO} 3=* \mathrm{Al}(\mathrm{OH}) 4$

$\mathrm{NO} 2-* \mathrm{Al}(\mathrm{OH}) 4$

$\mathrm{NO} 3-* \mathrm{Al}(\mathrm{OH}) 4$

$\mathrm{OH}-(\mathrm{M}) * \mathrm{Al}(\mathrm{OH}) 4-$

$\mathrm{SO} 4=* \mathrm{Al}(\mathrm{OH}) 4$

Temperature*Al(OH)4-

$\mathrm{NO} 2-* \mathrm{CO} 3=$

$\mathrm{NO} 3-* \mathrm{CO} 3=$

$\mathrm{OH}-(\mathrm{M}) * \mathrm{CO} 3=$

$\mathrm{SO} 4=* \mathrm{CO} 3=$

Temperature $* \mathrm{CO} 3=$

NO3-*NO2-

$\mathrm{OH}-(\mathrm{M}) * \mathrm{NO} 2-$

$\mathrm{SO} 4=* \mathrm{NO} 2$

Temperature*NO2-

$\mathrm{OH}-(\mathrm{M}) * \mathrm{NO} 3-$

$\mathrm{SO} 4=* \mathrm{NO} 3$

Temperature*NO3

$\mathrm{SO} 4=* \mathrm{OH}-(\mathrm{M})$

Temperature* $\mathrm{OH}-(\mathrm{M})$

Temperature*SO4=

$\mathrm{Al}(\mathrm{OH}) 4-* \mathrm{Al}(\mathrm{OH}) 4-$

$\mathrm{CO} 3=* \mathrm{CO} 3=$

$\mathrm{NO} 2-* \mathrm{NO} 2-$

$\mathrm{OH}-(\mathrm{M}) * \mathrm{OH}-(\mathrm{M})$

$\mathrm{SO} 4=* \mathrm{SO} 4=$

NO3-*NO3-
0.0040

Max RSq

$1.8749 \mathrm{e}-12$

1.0000

$\begin{array}{rrrr}\text { Estimate } & \text { Std Error } & \mathrm{t} \text { Ratio } & \text { Prob }>|\mathrm{t}| \\ 3.9965 \mathrm{e}-7 & 9.193 \mathrm{e}-7 & 0.43 & 0.6704 \\ 0.0000017 & 0.000004 & 0.47 & 0.6423 \\ -0.00002 & 0.000002 & -9.02 & <.0001 \\ -2.078 \mathrm{e}-7 & 6.047 \mathrm{e}-7 & -0.34 & 0.7363 \\ -2.97 \mathrm{e}-7 & 4.964 \mathrm{e}-7 & -0.60 & 0.5591 \\ -2.389 \mathrm{e}-9 & 8.931 \mathrm{e}-7 & -0.00 & 0.9979 \\ 0.0000052 & 0.000007 & 0.72 & 0.4849 \\ -1.478 \mathrm{e}-8 & 4.219 \mathrm{e}-8 & -0.35 & 0.7313 \\ -0.000005 & 0.000004 & -1.41 & 0.1795 \\ 5.8412 \mathrm{e}-7 & 0.000001 & 0.41 & 0.6868 \\ -0.000002 & 0.000001 & -1.96 & 0.0699 \\ 0.0000015 & 7.27 \mathrm{e}-7 & 2.00 & 0.0658 \\ 0.0000055 & 0.000008 & 0.70 & 0.4925 \\ -1.52 \mathrm{e}-7 & 1.45 \mathrm{e}-8 & -10.48 & <.0001 \\ 5.1294 \mathrm{e}-7 & 0.000001 & 0.36 & 0.7229 \\ 0.0000025 & 6.738 \mathrm{e}-7 & 3.77 & 0.0021 \\ 0.0000046 & 3.449 \mathrm{e}-7 & 13.21 & <.0001 \\ 0.0000177 & 0.000005 & 3.42 & 0.0041 \\ 3.2152 \mathrm{e}-8 & 2.036 \mathrm{e}-8 & 1.58 & 0.1367 \\ 1.0746 \mathrm{e}-7 & 1.179 \mathrm{e}-7 & 0.91 & 0.3777 \\ 3.5933 \mathrm{e}-7 & 6.726 \mathrm{e}-7 & 0.53 & 0.6016 \\ -6.42 \mathrm{e}-7 & 0.000002 & -0.36 & 0.7228 \\ -1.016 \mathrm{e}-8 & 1.1 \mathrm{e}-8 & -0.92 & 0.3713 \\ 2.1613 \mathrm{e}-7 & 9.215 \mathrm{e}-8 & 2.35 & 0.0343 \\ -0.000002 & 7.815 \mathrm{e}-7 & -2.19 & 0.0457 \\ 8.9304 \mathrm{e}-9 & 4.455 \mathrm{e}-9 & 2.00 & 0.0647 \\ 5.1816 \mathrm{e}-8 & 7.736 \mathrm{e}-7 & 0.07 & 0.9475 \\ 5.9143 \mathrm{e}-9 & 2.791 \mathrm{e}-9 & 2.12 & 0.0524 \\ 1.3449 \mathrm{e}-8 & 7.53 \mathrm{e}-8 & 0.18 & 0.8608 \\ 0.0000105 & 0.000005 & 2.20 & 0.0448 \\ 0.0000101 & 0.000002 & 6.01 & <.0001 \\ 7.089 \mathrm{e}-8 & 9.319 \mathrm{e}-8 & 0.76 & 0.4594 \\ 3.9105 \mathrm{e}-8 & 5.747 \mathrm{e}-8 & 0.68 & 0.5074 \\ -0.000005 & 0.000012 & -0.45 & 0.6596 \\ 4.2735 \mathrm{e}-8 & 1.333 \mathrm{e}-7 & 0.32 & 0.7533 \\ & & & \end{array}$

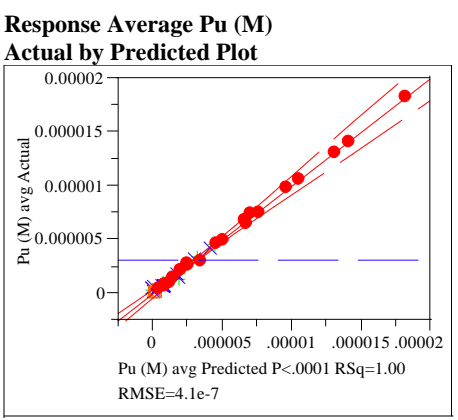

Summary of Fit

$\begin{array}{lr}\text { RSquare } & 0.997152 \\ \text { RSquare Adj } & 0.990237 \\ \text { Root Mean Square Error } & 4.087 \mathrm{e}-7 \\ \text { Mean of Response } & 0.000003 \\ \text { Observations (or Sum Wgts) } & 49\end{array}$

\begin{tabular}{|c|c|c|c|c|}
\hline \multicolumn{5}{|c|}{ Analysis of Variance } \\
\hline Source & $\mathrm{DF}$ & Sum of Squares & Mean Square & F Ratio \\
\hline Model & 34 & $8.1881 \mathrm{e}-10$ & $2.408 \mathrm{e}-11$ & 144.1851 \\
\hline Error & 14 & $2.3384 \mathrm{e}-12$ & $1.67 \mathrm{e}-13$ & Prob $>F$ \\
\hline C. Total & 48 & $8.2115 \mathrm{e}-10$ & & $<.0001$ \\
\hline
\end{tabular}

\section{Lack Of Fit}

Source

Lack Of Fit

$\begin{array}{rr}\text { DF } & \text { Sum of Squares } \\ 10 & 2.3072 \mathrm{e}-12\end{array}$

$2.3072 \mathrm{e}-12$
$3.1117 \mathrm{e}-14$

Mean Square

$2.307 \mathrm{e}-13$

F Ratio

Pure Error

$2.3384 \mathrm{e}-12$

$7.779 \mathrm{e}-15$

Prob > F

0.0026

Max RSq

1.0000

Parameter Estimates

Term

ntercept

$\mathrm{Al}(\mathrm{OH}) 4$

$\mathrm{CO} 3=$

$\mathrm{NO} 2-$

NO3-

$\mathrm{OH}-(\mathrm{M})$

$\mathrm{SO} 4=$

Temperature

$\mathrm{CO} 3=* \mathrm{Al}(\mathrm{OH}) 4-$

$\mathrm{NO} 2-* \mathrm{Al}(\mathrm{OH}) 4-$

$\mathrm{NO} 3-* \mathrm{Al}(\mathrm{OH}) 4-$

$\mathrm{OH}-(\mathrm{M}) * \mathrm{Al}(\mathrm{OH}) 4-$

$\mathrm{SO} 4=* \mathrm{Al}(\mathrm{OH}) 4-$

Temperature*Al(OH)4-

$\mathrm{NO} 2-* \mathrm{CO} 3=$

$\mathrm{NO} 3-* \mathrm{CO} 3=$

$\mathrm{OH}-(\mathrm{M}) * \mathrm{CO} 3=$

$\mathrm{SO} 4=* \mathrm{CO} 3=$

Temperature $* \mathrm{CO} 3=$

NO3-*NO2-

$\mathrm{OH}-(\mathrm{M}) * \mathrm{NO} 2-$

$\mathrm{SO} 4=* \mathrm{NO} 2$

Temperature*NO2-

$\mathrm{OH}-(\mathrm{M}) * \mathrm{NO} 3-$

$\mathrm{SO} 4=* \mathrm{NO} 3-$

Temperature*NO3-

$\mathrm{SO} 4=* \mathrm{OH}-(\mathrm{M})$

Temperature* ${ }^{*} \mathrm{H}-(\mathrm{M})$

Temperature*SO4=

$\mathrm{Al}(\mathrm{OH}) 4-* \mathrm{Al}(\mathrm{OH}) 4$

$\mathrm{CO} 3=* \mathrm{CO} 3=$

$\mathrm{NO} 2-* \mathrm{NO} 2-$

$\mathrm{OH}-(\mathrm{M}) * \mathrm{OH}-(\mathrm{M})$

$\mathrm{SO} 4=* \mathrm{SO} 4=$

NO3-*NO3-
Estimate

7.148e-7

0.0000094

$-0.000014$

$-6.127 \mathrm{e}-7$

$-5.73 e-7$

$-1.218 \mathrm{e}-7$

$-0.000003$

$-1.354 \mathrm{e}-8$

$-0.000006$

$-3.213 e-7$

$-0.000004$

$-0.000001$

0.0000178

$-1.233 \mathrm{e}-7$

0.0000014

0.0000011

0.0000039

0.0000164

$2.2571 \mathrm{e}-8$

$4.3019 \mathrm{e}-8$

$4.0199 \mathrm{e}-7$

0.000002

$-4.134 \mathrm{e}-9$

$2.3885 \mathrm{e}-7$

$-0.000001$

$-3.838 \mathrm{e}-9$

$4.3745 \mathrm{e}-7$

$6.5948 \mathrm{e}-9$

7.976e-8

0.000016

0.000007

$-4.046 \mathrm{e}-8$

$5.0279 \mathrm{e}-8$

$-0.000006$

$3.5526 \mathrm{e}-7$

$\begin{array}{rrr}\text { Std Error } & \text { t Ratio } & \text { Prob }>|\mathrm{t}| \\ 0.000001 & 0.70 & 0.4977 \\ 0.000004 & 2.32 & 0.0357 \\ 0.000002 & -5.88 & <.0001 \\ 6.753 \mathrm{e}-7 & -0.91 & 0.3796 \\ 5.544 \mathrm{e}-7 & -1.03 & 0.3189 \\ 9.974 \mathrm{e}-7 & -0.12 & 0.9045 \\ 0.000008 & -0.42 & 0.6826 \\ 4.712 \mathrm{e}-8 & -0.29 & 0.7781 \\ 0.000004 & -1.46 & 0.1654 \\ 0.000002 & -0.20 & 0.8422 \\ 0.000001 & -3.78 & 0.0020 \\ 8.119 \mathrm{e}-7 & -1.67 & 0.1173 \\ 0.000009 & 2.04 & 0.0609 \\ 1.619 \mathrm{e}-8 & -7.61 & <.0001 \\ 0.000002 & 0.86 & 0.4057 \\ 7.525 \mathrm{e}-7 & 1.52 & 0.1498 \\ 3.85 \mathrm{e}-7 & 10.12 & <.0001 \\ 0.000006 & 2.85 & 0.0129 \\ 2.274 \mathrm{e}-8 & 0.99 & 0.3377 \\ 1.317 \mathrm{e}-7 & 0.33 & 0.7488 \\ 7.511 \mathrm{e}-7 & 0.54 & 0.6009 \\ 0.000002 & 1.02 & 0.3261 \\ 1.229 \mathrm{e}-8 & -0.34 & 0.7416 \\ 1.029 \mathrm{e}-7 & 2.32 & 0.0359 \\ 8.727 \mathrm{e}-7 & -1.61 & 0.1293 \\ 4.975 \mathrm{e}-9 & -0.77 & 0.4533 \\ 8.639 \mathrm{e}-7 & 0.51 & 0.6205 \\ 3.117 \mathrm{e}-9 & 2.12 & 0.0527 \\ 8.41 \mathrm{e}-8 & 0.95 & 0.3590 \\ 0.000005 & 3.03 & 0.0090 \\ 0.000002 & 3.73 & 0.0022 \\ 1.041 \mathrm{e}-7 & -0.39 & 0.7033 \\ 6.419 \mathrm{e}-8 & 0.78 & 0.4465 \\ 0.000013 & -0.46 & 0.6523 \\ 1.489 \mathrm{e}-7 & 2.39 & 0.0317\end{array}$


Exhibit D.7 Stepwise Model Fit to the Historical Data with, in turn, the Average and Individual Sample Pu Data from this Study

Response Average Pu (M)

Actual by Predicted Plot

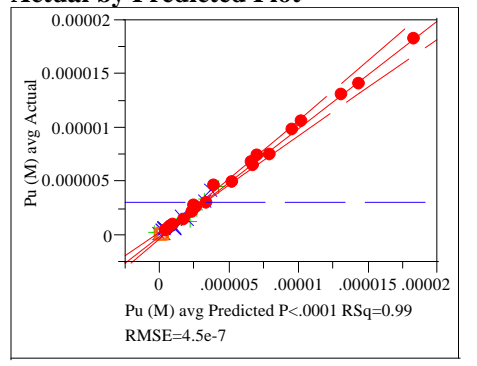

Summary of Fit

RSquare

0.993479

RSquare Adj

Root Mean Square Error

0.987962

Mean of Response

$4.538 \mathrm{e}-7$

0.000003

Observations (or Sum Wgts)

49

Analysis of Variance

$\begin{array}{lrrrr}\text { Source } & \text { DF } & \text { Sum of Squares } & \text { Mean Square } & \text { F Ratio } \\ \text { Model } & 22 & 8.1579 \mathrm{e}-10 & 3.708 \mathrm{e}-11 & 180.0582 \\ \text { Error } & 26 & 5.3545 \mathrm{e}-12 & 2.059 \mathrm{e}-13 & \text { Prob > F } \\ \text { C. Total } & 48 & 8.2115 \mathrm{e}-10 & & <.0001\end{array}$

Lack Of Fit

$\begin{array}{lrrrr}\text { Source } & \text { DF } & \text { Sum of Squares } & \text { Mean Square } & \text { F Ratio } \\ \text { Lack Of Fit } & 22 & 5.3234 \mathrm{e}-12 & 2.42 \mathrm{e}-13 & 31.1050 \\ \text { Pure Error } & 4 & 3.1117 \mathrm{e}-14 & 7.779 \mathrm{e}-15 & \text { Prob > F } \\ \text { Total Error } & 26 & 5.3545 \mathrm{e}-12 & & 0.0021 \\ & & & & \text { Max RSq } \\ & & & & 1.0000\end{array}$

Parameter Estimates

Term

Intercept

$\mathrm{Al}(\mathrm{OH}) 4-$

$\mathrm{CO} 3=$

NO2-

NO3-

$\mathrm{OH}-(\mathrm{M})$

$\mathrm{SO} 4=$

Temperature

$\mathrm{CO} 3=* \mathrm{Al}(\mathrm{OH}) 4-$

$\mathrm{NO} 2-* \mathrm{Al}(\mathrm{OH}) 4$

$\mathrm{NO} 3-* \mathrm{Al}(\mathrm{OH}) 4-$

$\mathrm{SO} 4=* \mathrm{Al}(\mathrm{OH}) 4$

Temperature* $\mathrm{Al}(\mathrm{OH}) 4$ -

$\mathrm{NO} 2-* \mathrm{CO} 3=$

$\mathrm{NO} 3-* \mathrm{CO} 3=$

$\mathrm{OH}-(\mathrm{M}) * \mathrm{CO} 3=$

$\mathrm{SO} 4=* \mathrm{CO} 3=$

Temperature $* \mathrm{CO} 3=$

SO4=*NO3-

Temperature*OH- (M)

Temperature $* \mathrm{SO} 4=$

$\mathrm{Al}(\mathrm{OH}) 4-* \mathrm{Al}(\mathrm{OH}) 4$

$\mathrm{CO} 3=* \mathrm{CO} 3=$

$\begin{array}{rrrr}\text { Estimate } & \text { Std Error } & \text { t Ratio } & \text { Prob }>|\mathrm{t}| \\ -1.015 \mathrm{e}-7 & 2.976 \mathrm{e}-7 & -0.34 & 0.7358 \\ 0.000002 & 0.000002 & 0.94 & 0.3540 \\ -0.000015 & 0.000002 & -6.68 & <.0001 \\ -2.371 \mathrm{e}-7 & 1.44 \mathrm{e}-7 & -1.65 & 0.1117 \\ 7.5769 \mathrm{e}-7 & 1.229 \mathrm{e}-7 & 6.17 & <.0001 \\ 7.3388 \mathrm{e}-7 & 5.063 \mathrm{e}-8 & 14.49 & <.0001 \\ -0.000002 & 0.000003 & -0.65 & 0.5225 \\ -3.535 \mathrm{e}-8 & 8.106 \mathrm{e}-9 & -4.36 & 0.0002 \\ -0.000004 & 0.000001 & -2.80 & 0.0096 \\ 0.0000011 & 4.122 \mathrm{e}-7 & 2.78 & 0.0100 \\ -0.000002 & 4.818 \mathrm{e}-7 & -4.08 & 0.0004 \\ 0.0000129 & 0.000005 & 2.54 & 0.0173 \\ -1.164 \mathrm{e}-7 & 1.493 \mathrm{e}-8 & -7.79 & <.0001 \\ 0.0000015 & 3.115 \mathrm{e}-7 & 4.82 & <.0001 \\ 0.0000013 & 2.153 \mathrm{e}-7 & 6.12 & <.0001 \\ 0.0000037 & 2.411 \mathrm{e}-7 & 15.42 & <.0001 \\ 0.0000123 & 0.000004 & 3.51 & 0.0016 \\ 2.2612 \mathrm{e}-8 & 1.028 \mathrm{e}-8 & 2.20 & 0.0369 \\ -0.000001 & 4.791 \mathrm{e}-7 & -2.85 & 0.0084 \\ 8.1391 \mathrm{e}-9 & 9.45 \mathrm{e}-10 & 8.61 & <.0001 \\ 9.2169 \mathrm{e}-8 & 3.052 \mathrm{e}-8 & 3.02 & 0.0056 \\ 0.0000108 & 0.000003 & 3.65 & 0.0012 \\ 0.0000089 & 0.000001 & 6.00 & <.0001\end{array}$

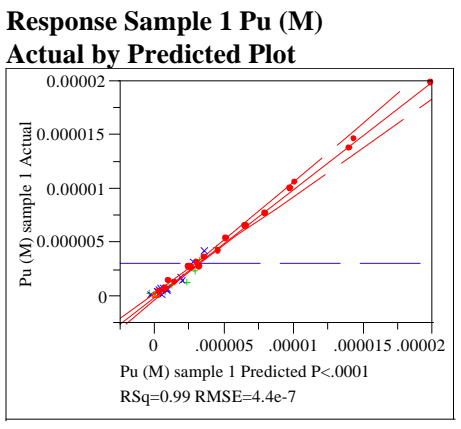

Summary of Fit

$\begin{array}{lr}\text { RSquare } & 0.994357 \\ \text { RSquare Adj } & 0.989581 \\ \text { Root Mean Square Error } & 4.359 \mathrm{e}-7 \\ \text { Mean of Response } & 0.000003 \\ \text { Observations (or Sum Wgts) } & 49\end{array}$

$\begin{array}{lrrrr}\text { Analysis of Variance } & & & \\ \text { Source } & \text { DF } & \text { Sum of Squares } & \text { Mean Square } & \text { F Ratio } \\ \text { Model } & 22 & 8.706 \mathrm{e}-10 & 3.957 \mathrm{e}-11 & 208.2314 \\ \text { Error } & 26 & 4.9411 \mathrm{e}-12 & 1.9 \mathrm{e}-13 & \text { Prob }>\text { F } \\ \text { C. Total } & 48 & 8.7554 \mathrm{e}-10 & & <.0001\end{array}$

Lack Of Fit

Source DF Sum of Squares Mean Square F Ratio

Lack Of Fit $22 \quad 4.91 \mathrm{e}-12 \quad 2.232 \mathrm{e}-13 \quad 28.6894$

$\begin{array}{llll}\text { Pure Error } & 4 & 3.1117 \mathrm{e}-14 \quad 7.779 \mathrm{e}-15 \quad \text { Prob }>\text { F }\end{array}$

Total Error $26 \quad 4.9411 \mathrm{e}-12 \quad 0.0025$

$\operatorname{Max} \mathrm{RSq}$

1.0000

Parameter Estimates

Term

Intercept

$\mathrm{Al}(\mathrm{OH}) 4-$

$\mathrm{CO} 3=$

NO2-

NO3-

$\mathrm{OH}-$ (M)

SO4=

Temperature

$\mathrm{CO} 3=* \mathrm{Al}(\mathrm{OH}) 4-$

$\mathrm{NO} 2-* \mathrm{Al}(\mathrm{OH}) 4-$

$\mathrm{NO} 3-* \mathrm{Al}(\mathrm{OH}) 4-$

$\mathrm{SO} 4=* \mathrm{Al}(\mathrm{OH}) 4-$

Temperature* $\mathrm{Al}(\mathrm{OH}) 4$ -

$\mathrm{NO} 2-* \mathrm{CO} 3=$

$\mathrm{NO} 3-* \mathrm{CO} 3=$

$\mathrm{OH}-(\mathrm{M}) * \mathrm{CO} 3=$

$\mathrm{SO} 4=* \mathrm{CO} 3=$

Temperature $* \mathrm{CO} 3=$

$\mathrm{SO} 4=* \mathrm{NO} 3$ -

Temperature*OH- (M)

Temperature $* \mathrm{SO} 4=$

$\mathrm{Al}(\mathrm{OH}) 4-* \mathrm{Al}(\mathrm{OH}) 4-$

$\mathrm{CO} 3=* \mathrm{CO} 3=$

$\begin{array}{rrrr}\text { Estimate } & \text { Std Error } & \text { t Ratio } & \text { Prob>|t| } \\ -4.931 \mathrm{e}-7 & 2.859 \mathrm{e}-7 & -1.73 & 0.0964 \\ 6.0509 \mathrm{e}-7 & 0.000002 & 0.30 & 0.7650 \\ -0.000015 & 0.000002 & -6.93 & <.0001 \\ -1.561 \mathrm{e}-7 & 1.383 \mathrm{e}-7 & -1.13 & 0.2693 \\ 7.7117 \mathrm{e}-7 & 1.18 \mathrm{e}-7 & 6.53 & <.0001 \\ 8.3717 \mathrm{e}-7 & 4.864 \mathrm{e}-8 & 17.21 & <.0001 \\ 7.8905 \mathrm{e}-7 & 0.000003 & 0.29 & 0.7772 \\ -2.717 \mathrm{e}-8 & 7.787 \mathrm{e}-9 & -3.49 & 0.0017 \\ -0.000002 & 0.000001 & -1.66 & 0.1088 \\ 0.000001 & 3.96 \mathrm{e}-7 & 2.58 & 0.0158 \\ -0.000002 & 4.628 \mathrm{e}-7 & -4.16 & 0.0003 \\ 0.0000046 & 0.000005 & 0.94 & 0.3547 \\ -1.022 \mathrm{e}-7 & 1.435 \mathrm{e}-8 & -7.12 & <.0001 \\ 0.0000017 & 2.993 \mathrm{e}-7 & 5.66 & <.0001 \\ 9.1776 \mathrm{e}-7 & 2.068 \mathrm{e}-7 & 4.44 & 0.0001 \\ 0.0000033 & 2.316 \mathrm{e}-7 & 14.26 & <.0001 \\ 0.0000118 & 0.000003 & 3.51 & 0.0016 \\ 2.6772 \mathrm{e}-8 & 9.875 \mathrm{e}-9 & 2.71 & 0.0117 \\ -0.000001 & 4.602 \mathrm{e}-7 & -2.76 & 0.0105 \\ 7.9575 \mathrm{e}-9 & 9.08 \mathrm{e}-10 & 8.76 & <.0001 \\ 4.9842 \mathrm{e}-8 & 2.932 \mathrm{e}-8 & 1.70 & 0.1011 \\ 0.0000129 & 0.000003 & 4.55 & 0.0001 \\ 0.0000091 & 0.000001 & 6.34 & <.0001\end{array}$


Exhibit D.7 Stepwise Model Fit to the Historical Data with, in turn, the Average and Individual Sample Pu Data from this Study (continued)

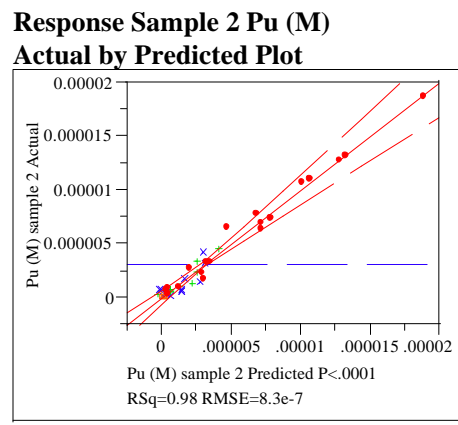

Summary of Fit

RSquare

RSquare Adj

Root Mean Square Error

Mean of Response

Observations (or Sum Wgts)

0.978685

0.96065

$8.314 \mathrm{e}-7$

0.000003

49

Analysis of Variance

$\begin{array}{lrrrr}\text { Source } & \text { DF } & \text { Sum of Squares } & \text { Mean Square } & \text { F Ratio } \\ \text { Model } & 22 & 8.2517 \mathrm{e}-10 & 3.751 \mathrm{e}-11 & 54.2645 \\ \text { Error } & 26 & 1.7971 \mathrm{e}-11 & 6.912 \mathrm{e}-13 & \text { Prob }>\text { F } \\ \text { C. Total } & 48 & 8.4314 \mathrm{e}-10 & & <.0001\end{array}$

\section{Lack Of Fit}

Source

Lack Of Fit 22

DF Sum of Squares

Pure Error 4

Total Error $\quad 26$

$1.794 \mathrm{e}-1$

$3.1117 \mathrm{e}-14$

$1.7971 \mathrm{e}-11$

Mean Square

8.155e-13

7.779e-15

F Ratio

104.8262

Prob > F

0.0002

Max RSq

1.0000

Parameter Estimates

Term

Intercept

$\mathrm{Al}(\mathrm{OH}) 4-$

$\mathrm{CO} 3=$

$\mathrm{NO} 2-$

NO3-

OH- (M)

$\mathrm{SO} 4=$

Temperature

$\mathrm{CO} 3=* \mathrm{Al}(\mathrm{OH}) 4$

$\mathrm{NO} 2-* \mathrm{Al}(\mathrm{OH}) 4$

$\mathrm{NO} 3-* \mathrm{Al}(\mathrm{OH}) 4$

$\mathrm{SO} 4=* \mathrm{Al}(\mathrm{OH}) 4$

Temperature* $\mathrm{Al}(\mathrm{OH}) 4-$

$\mathrm{NO} 2-* \mathrm{CO} 3=$

$\mathrm{NO} 3-* \mathrm{CO} 3=$

$\mathrm{OH}-(\mathrm{M}) * \mathrm{CO} 3=$

$\mathrm{SO} 4={ }^{*} \mathrm{CO} 3=$

Temperature $* \mathrm{CO} 3=$

$\mathrm{SO} 4=* \mathrm{NO} 3$

Temperature* $\mathrm{OH}-(\mathrm{M})$

Temperature*SO4=

$\mathrm{Al}(\mathrm{OH}) 4-* \mathrm{Al}(\mathrm{OH}) 4$

$\mathrm{CO} 3=* \mathrm{CO} 3=$

$\begin{array}{rrrr}\text { Estimate } & \text { Std Error } & \text { t Ratio } & \text { Prob }>|t| \\ 5.3117 \mathrm{e}-7 & 5.452 \mathrm{e}-7 & 0.97 & 0.3389 \\ 1.9755 \mathrm{e}-7 & 0.000004 & 0.05 & 0.9592 \\ -0.000009 & 0.000004 & -2.18 & 0.0381 \\ -4.019 \mathrm{e}-7 & 2.638 \mathrm{e}-7 & -1.52 & 0.1397 \\ 7.8594 \mathrm{e}-7 & 2.251 \mathrm{e}-7 & 3.49 & 0.0017 \\ 6.5095 \mathrm{e}-7 & 9.276 \mathrm{e}-8 & 7.02 & <.0001 \\ -0.000004 & 0.000005 & -0.83 & 0.4131 \\ -5.748 \mathrm{e}-8 & 1.485 \mathrm{e}-8 & -3.87 & 0.0007 \\ -6.279 \mathrm{e}-7 & 0.000003 & -0.23 & 0.8192 \\ 0.000002 & 7.552 \mathrm{e}-7 & 2.63 & 0.0143 \\ -0.000001 & 8.827 \mathrm{e}-7 & -1.42 & 0.1672 \\ 0.0000192 & 0.000009 & 2.07 & 0.0488 \\ -1.08 \mathrm{e}-7 & 2.736 \mathrm{e}-8 & -3.95 & 0.0005 \\ 0.0000015 & 5.708 \mathrm{e}-7 & 2.61 & 0.0150 \\ 5.515 \mathrm{e}-7 & 3.944 \mathrm{e}-7 & 1.40 & 0.1738 \\ 0.0000032 & 4.417 \mathrm{e}-7 & 7.32 & <.0001 \\ 0.000005 & 0.000006 & 0.78 & 0.4435 \\ -3.393 \mathrm{e}-9 & 1.883 \mathrm{e}-8 & -0.18 & 0.8584 \\ -0.000001 & 8.777 \mathrm{e}-7 & -1.62 & 0.1166 \\ 1.0529 \mathrm{e}-8 & 1.732 \mathrm{e}-9 & 6.08 & <.0001 \\ 1.6584 \mathrm{e}-7 & 5.591 \mathrm{e}-8 & 2.97 & 0.0064 \\ 0.0000066 & 0.000005 & 1.22 & 0.2339 \\ 0.0000073 & 0.000003 & 2.69 & 0.0124\end{array}$

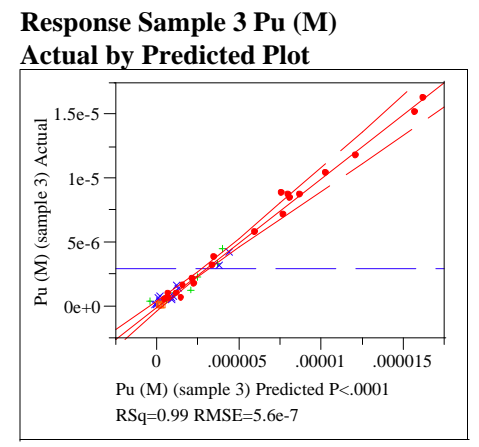

Summary of Fit

0.989925

RSquare Adj

0.981399

Root Mean Square Error $\quad 5.59 \mathrm{e}-7$

Mean of Response

0.000003

Observations (or Sum Wgts)

49

Analysis of Variance

$\begin{array}{lrrrr}\text { Source } & \text { DF } & \text { Sum of Squares } & \text { Mean Square } & \text { F Ratio } \\ \text { Model } & 22 & 7.9821 \mathrm{e}-10 & 3.628 \mathrm{e}-11 & 116.1166 \\ \text { Error } & 26 & 8.124 \mathrm{e}-12 & 3.125 \mathrm{e}-13 & \text { Prob > F } \\ \text { C. Total } & 48 & 8.0633 \mathrm{e}-10 & & <.0001\end{array}$

Lack Of Fit

Source DF Sum of Squares Mean Square F Ratio

Lack Of Fit $22 \quad 8.0929 \mathrm{e}-12$

$\begin{array}{lrlll}\text { Pure Error } \quad 4 & 3.1117 \mathrm{e}-14 & 7.779 \mathrm{e}-15 & \text { Prob }>\text { F }\end{array}$

$\begin{array}{llll}\text { Total Error } & 26 & 8.124 \mathrm{e}-12 & 0.0009\end{array}$

Max RSq

1.0000

Parameter Estimates

Term

Intercept

$\mathrm{Al}(\mathrm{OH}) 4-$

$\mathrm{CO} 3=$

$\mathrm{NO} 2-$

NO3-

$\mathrm{OH}-(\mathrm{M})$

$\mathrm{SO} 4=$

Temperature

$\mathrm{CO} 3=* \mathrm{Al}(\mathrm{OH}) 4-$

$\mathrm{NO} 2-* \mathrm{Al}(\mathrm{OH}) 4-$

$\mathrm{NO} 3-* \mathrm{Al}(\mathrm{OH}) 4-$

$\mathrm{SO} 4=* \mathrm{Al}(\mathrm{OH}) 4-$

Temperature* $\mathrm{Al}(\mathrm{OH}) 4-$

$\mathrm{NO} 2-* \mathrm{CO} 3=$

$\mathrm{NO} 3-* \mathrm{CO} 3=$

$\mathrm{OH}-(\mathrm{M}) * \mathrm{CO} 3=$

$\mathrm{SO} 4=* \mathrm{CO} 3=$

Temperature* $\mathrm{CO} 3=$

$\mathrm{SO} 4=* \mathrm{NO} 3-$

Temperature* $\mathrm{OH}-(\mathrm{M})$

Temperature*SO4=

$\mathrm{Al}(\mathrm{OH}) 4-* \mathrm{Al}(\mathrm{OH}) 4-$

$\mathrm{CO} 3=* \mathrm{CO} 3=$

$\begin{array}{rrrr}\text { Estimate } & \text { Std Error } & \mathrm{t} \text { Ratio } & \text { Prob }>|\mathrm{t}| \\ -3.425 \mathrm{e}-7 & 3.665 \mathrm{e}-7 & -0.93 & 0.3587 \\ 0.0000051 & 0.000003 & 1.99 & 0.0577 \\ -0.000021 & 0.000003 & -7.62 & <.0001 \\ -1.533 \mathrm{e}-7 & 1.774 \mathrm{e}-7 & -0.86 & 0.3954 \\ 7.1595 \mathrm{e}-7 & 1.513 \mathrm{e}-7 & 4.73 & <.0001 \\ 7.1354 \mathrm{e}-7 & 6.237 \mathrm{e}-8 & 11.44 & <.0001 \\ -0.000002 & 0.000004 & -0.56 & 0.5772 \\ -2.14 \mathrm{e}-8 & 9.985 \mathrm{e}-9 & -2.14 & 0.0417 \\ -0.000009 & 0.000002 & -5.17 & <.0001 \\ 4.2841 \mathrm{e}-7 & 5.078 \mathrm{e}-7 & 0.84 & 0.4065 \\ -0.000003 & 5.935 \mathrm{e}-7 & -4.57 & 0.0001 \\ 0.0000149 & 0.000006 & 2.38 & 0.0249 \\ -1.389 \mathrm{e}-7 & 1.84 \mathrm{e}-8 & -7.55 & <.0001 \\ 0.0000013 & 3.838 \mathrm{e}-7 & 3.45 & 0.0019 \\ 0.0000025 & 2.652 \mathrm{e}-7 & 9.37 & <.0001 \\ 0.0000046 & 2.97 \mathrm{e}-7 & 15.56 & <.0001 \\ 0.0000201 & 0.000004 & 4.65 & <.0001 \\ 4.4457 \mathrm{e}-8 & 1.266 \mathrm{e}-8 & 3.51 & 0.0016 \\ -0.000001 & 5.901 \mathrm{e}-7 & -2.38 & 0.0252 \\ 5.9309 \mathrm{e}-9 & 1.165 \mathrm{e}-9 & 5.09 & <.0001 \\ 6.0825 \mathrm{e}-8 & 3.759 \mathrm{e}-8 & 1.62 & 0.1177 \\ 0.0000128 & 0.000004 & 3.53 & 0.0016 \\ 0.0000104 & 0.000002 & 5.68 & <.0001\end{array}$

